Florida International University FIU Digital Commons

\title{
Responses of Four Non-tidal Forest Communities of the Florida Everglades to Hurricane Impact over 21 Years
}

Jeremy L. May

Florida International University, jmay010@fiu.edu

DOI: 10.25148 /etd.FIDC000257

Follow this and additional works at: https://digitalcommons.fiu.edu/etd

Part of the Other Ecology and Evolutionary Biology Commons, and the Terrestrial and Aquatic Ecology Commons

\section{Recommended Citation}

May, Jeremy L., "Responses of Four Non-tidal Forest Communities of the Florida Everglades to Hurricane Impact over 21 Years" (2016). FIU Electronic Theses and Dissertations. 2467.

https://digitalcommons.fiu.edu/etd/2467 


\title{
FLORIDA INTERNATIONAL UNIVERSITY
}

Miami, Florida

RESPONSES OF FOUR NON-TIDAL FOREST COMMUNITIES

OF THE FLORIDA EVERGLADES TO HURRICANE IMPACT OVER 21 YEARS

\author{
A dissertation submitted in partial fulfillment of the \\ requirements for the degree of \\ DOCTOR OF PHILOSOPHY \\ in \\ BIOLOGY \\ by
}

Jeremy L. May

2016 
To: Dean Michael R. Heithaus

College of Arts, Sciences, and Education

This dissertation, written by Jeremy May, and entitled Responses of Four Non-tidal Forest Communities of the Florida Everglades to Hurricane Impact over 21 Years, having been approved in respect to style and intellectual content, is referred to you for judgment.

We have read this dissertation and recommend that it be approved.

Suzanne Koptur

Jennifer Richards

Michael Ross

Kevin R. T. Whelan

Steven Oberbauer, Major Professor

Date of Defense: March 30, 2016

The dissertation of Jeremy L. May is approved.

Dean Michael R. Heithaus

College of Arts, Sciences, and Education

Andrés G. Gil

Vice President for Research and Economic Development and Dean of the University Graduate School

Florida International University, 2016 
(C) Copyright 2016 by Jeremy L. May

All rights reserved. 


\section{DEDICATION}

I dedicate this dissertation to my ever patient and loving wife, Jessica. Without your support and encouragement none of this would have been possible. You have my unending love and gratitude. 


\section{ACKNOWLEDGMENTS}

I would like to thank my committee members for their insight and guidance in developing this project. Their review and comments of the manuscripts within have been immensely helpful in the development. In particular, I would like to thank my major professor, Dr. Steve Oberbauer. His encouragement and guidance has allowed me to develop my skills as a scientist and broaden the scope of my interests that will ensure excellence in my future.

I would also like to thank the volunteers that have put in countless hours in the field; Max Olzsack, Jeffrey Summers, and Steven Unger. Without all of your sweat, perseverance, and mosquito bites none of this would have been possible. I would also like to thank Joe O’Brien for use of his Li-Cor 6400XT during my shadehouse experiment sampling.

Thanks to my wife, Jessica Brautigam, for her support and encouragement throughout all aspects of this process and my life. None of this would have been possible without your hard work and dedication to me and this project.

Last but not least, I would like to thank my family. Thanks to my parents, Gary and Brenda May, for instilling in me a strong work ethic and a love for the outdoors at an early age. My brother, Heath May, and my best friend, Ben Tokarski, for the countless hours we spent running through the woods and learning to ask the questions of how the natural world works. 


\begin{abstract}
OF THE DISSERTATION
RESPONSES OF FOUR NON-TIDAL FOREST COMMUNITIES OF THE FLORIDA EVERGLADES TO HURRICANE IMPACT OVER 21 YEARS
\end{abstract}

by

Jeremy L. May

Florida International University, 2016

Miami, Florida

Professor Steven Oberbauer, Major Professor

The regular occurrence of hurricane-associated winds has been an important factor in shaping the structure and composition of the forest ecosystems of the Florida Everglades. Forest communities in the Everglades are adapted to hurricane disturbances, but increased frequency and/or intensity of hurricanes may lead to decline or even collapse of these communities. The overall objective of this project is to understand the patterns, pace, and mechanisms of the recovery process to Hurricane Andrew damage in four Everglade forest communities: pinelands, hardwood hammocks, bayhead tree islands, and cypress domes. This study combines long- and short-term field measurements and experimental garden studies to determine how the four woody plant community types recover from hurricane impacts. Most of the community types were adversely affected by storm damage in the short-term (3 years post-hurricane) through altered growth rates and canopy defoliation, however these effects were relatively short 
lived and were not visible in shifts in species composition after the long-term (20 year) recovery period. Only in the most diverse communities over the long-term there was a delayed mortality in damaged individuals that drove a diversity loss. This loss was not present over the short-term recovery time period. Using individual damage extent and short-term recovery growth rates, I developed a simplified model that accurately predicted surviving individual stem size over long-term recovery periods of Taxodium distichum within cypress domes and select hardwood hammock species. The shadehouse experiments demonstrated the importance of nutrient availability to growth of seedlings of canopy dominants. Recruits of these species responded to changing environmental conditions associated with storm impact through a variety of strategies in accordance with their adaptive traits. Synergistically, the combined parts of this dissertation demonstrate directional community and species-specific shifts that vary over time scales. Storm impacts have the potential to alter community composition and diversity within impacted systems, and in particular the Everglades ecosystem. 


\section{TABLE OF CONTENTS}

CHAPTER

PAGE

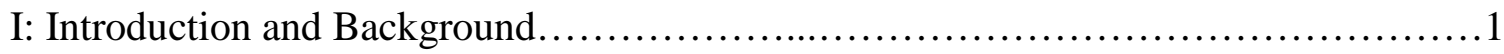

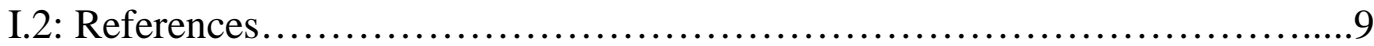

II: Temporal Changes in Community Structure and Function Following Hurricane Andrew Impact in Four Non-Tidal Forest Communities in the Florida Everglades.......19

II.1: Abstract..................................................................19

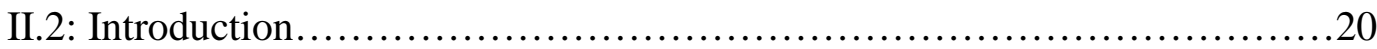

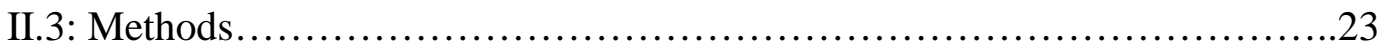

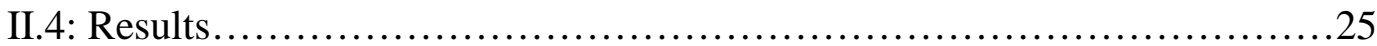

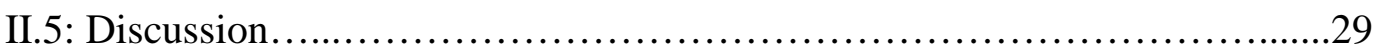

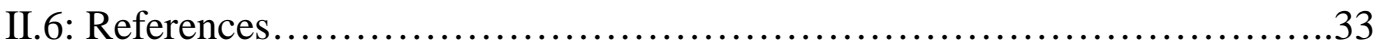

III: Species Diversity Shifts in Response to Hurricane Impact in Four Non-Tidal Forest Communities over Varying Time Scales in the Florida Everglades................51

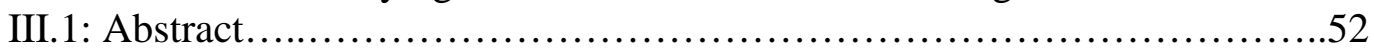

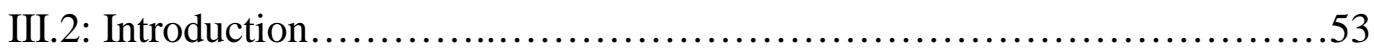

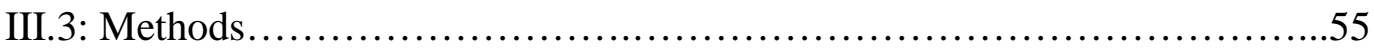

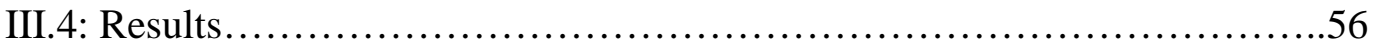

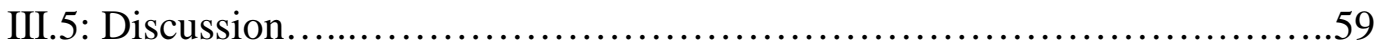

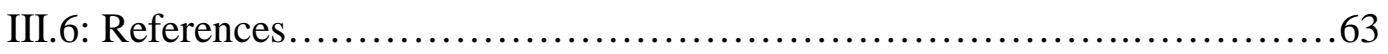

IV: A Predictive Model of Canopy-Level Individual Growth Rates after 19 Years of Recovery from Hurricane Andrew................................................ 81

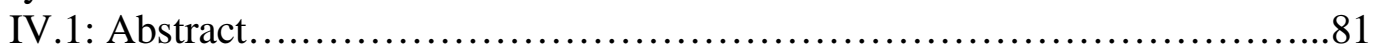

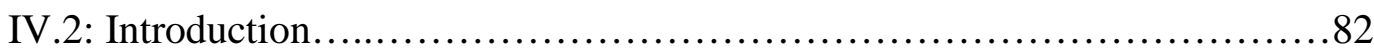

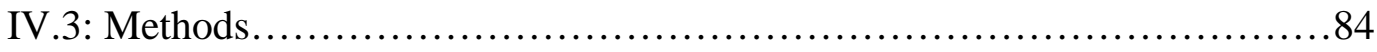

IV.3.1: Site Description and Field Sampling..................................84

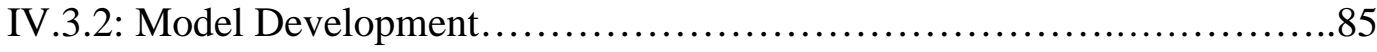

IV.3.3: Model Testing ................................................. 88

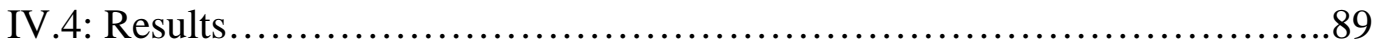

IV.5: Discussion........................................................ 91

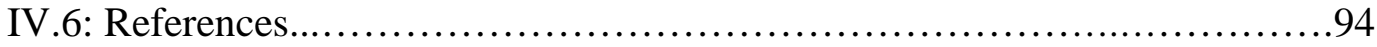

V: Growth Rate and Resource Allocation Responses of Canopy Species Seedlings from Four Everglades Plant Communities to Varying Light and Nutrient Regimes......111

V.1:Abstract..............................................................111

V.2: Introduction......................................................

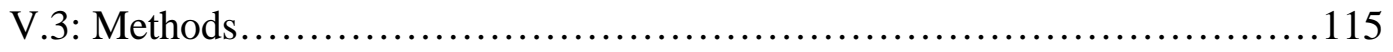

V.3.1: Experimental Design..............................................115

V.3.2: Data Analysis.....................................................117

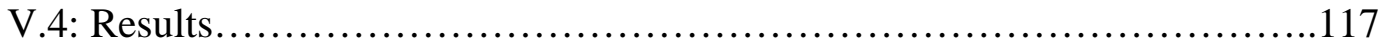


V.4.1: Height Growth...................................................117

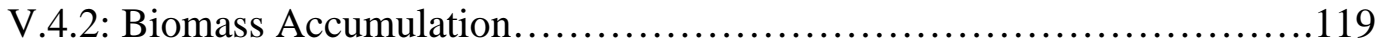

V.4.3: Photosynthesis Estimates.........................................120

V.4.4: Tissue N, C Content and Isotope Values..............................121

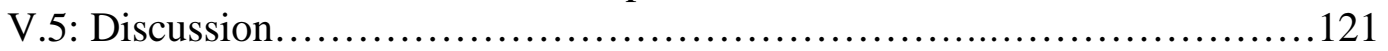

V.6: References................................................. 127

VI: Synthesis and Relevance................................................143

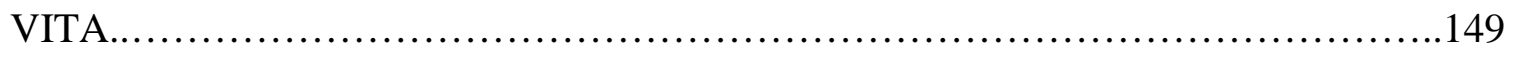




\section{LIST OF TABLES}

TABLE

PAGE

Table II.1: Damage classifications for initial vegetation assessments with number and proportions of affected individuals.

Table II.2: Species yearly growth rates for tagged individuals surviving across the short- (1993-96), intermediate- (1996-12), and long-term time scales for all for

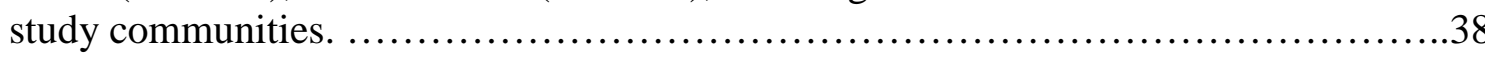

Table II.3: Soil and leaf percent nitrogen content by community type and site.

Table III.1: Damage classifications for initial vegetation assessments with number and proportions of affected individuals.

Table III.2: Frequency changes in the total number of individuals and individuals tagged in the initial (1993) survey over short- (1996) and long-term (2012-13) recovery time periods.

Table III.3: Growth and mortality of individuals present at the initial survey (1993) into size class after the short-term recovery period (1996)....

Table III.4: Growth and mortality of individuals present at the initial survey (1993) into size class after the long-term recovery period (2012-13).

Table III.5: Diversity shifts within four forest community plots over short- (3 year) and long-term (20 year) recovery from Hurricane Andrew............................75

Table IV.1: Damage assessment from initial community surveys and model parameter numeric categories for all individuals

Table IV.2: Survival rates of tagged individuals between 1993 and 2012-13, number of individuals included as parameter components for model development, and number of individuals included in model performance testing....................98

Table IV.3: Model Parameter category for all species across all communities with $\mathrm{R}^{2}$ and statistical significances from correlation analysis.

Table IV.4: Number of individuals and model M2 coefficients for each species included in model performance testing with actual size after 19 years of growth (2012-13) and model predicted size. 102 
Table IV.5: M2 model variable averages (Ave) and standard deviations (SD), including sensitivity analysis maximum (Max) and minimum (Min) solutions with Sensitivity Index (SI).

Table V.1: Total dry biomass (including root, shoot, and leaf percentages), total leaf area, relative growth rate (RGR), root:shoot ratio, and specific leaf area (SLA) for all four species across all treatment types.

Table V.2: Total dry biomass (including root, shoot, and leaf percentages), total leaf area, relative growth rate (RGR), root:shoot ratio, and specific leaf area (SLA) for all four species for low nutrient/low light (LNLL) and post-hurricane simulation treatments.

Table V.3: Leaf percent nitrogen and $\delta^{13} \mathrm{C}$ isotopic content for all species across all treatment types

Table V.4: Leaf nitrogen percent and $\delta^{13} \mathrm{C}$ isotopic content for all species for low nutrient/low light (LNLL) and post-hurricane simulation treatments.... 


\section{LIST OF FIGURES}

\section{FIGURE}

PAGE

Figure I.1: Examples of Hurricane Andrew damage in Everglades National Park forest communities (circa 1992).......................................... 15

Figure I.2: Infrared image of Hurricane Andrew eye-wall landfall August 24, 1992 (National Oceanographic and Atmospheric Administration).

Figure I.3: Geographic track of Hurricane Andrew eye center (solid line) and eye-wall edge (dashed lines) across South Florida.

Figure I.4: Flowchart describing field and shadehouse components of the project and the relation of these components to the main research questions

Figure II.1: Upper: Overview of geographic location of all 12 field sites within Everglades National Park. Lower: Specific community positions along Main

Park Road

Figure II.2: Diagram of the $5 \mathrm{~m} x \mathrm{~m}$ survey plots for bayhead tree islands, cypress domes, and hardwood hammocks, and 10m x 20m survey plots in pinelands and their orientation along transects within a community...

Figure II.3: Monthly growth rates (diameter) of $T$. distichum (light grey dashed), P. elliottii (light grey solid), Q. virginiana in hardwood hammocks (dark grey dashed) and bayhead tree islands (dark grey solid), and B. simaruba in hardwood hammocks (black dashed) and bayhead tree islands (black solid).

Figure II.4: Canopy closure of cypress dome (dotted), hardwood hammock (solid), and pineland (dashed) communities during the recovery after Hurricane Andrew....

Figure II.5: Canopy cover associated with position along survey transects for hardwood hammocks (grey dotted), cypress dome (grey solid), pineland (black solid), and bayhead tree island (black dashed).

Figure II.6: Canopy cover in cypress dome (A), pineland (B), bayhead tree island (C), and hardwood hammock (D) community plots after 21 years (2014) of recovery post Hurricane Andrew, compared to initial (1993) average plot damage...............46

Figure II.7: Leaf nitrogen content with position along survey transects for hardwood hammocks (grey dotted), cypress dome (grey solid), pineland (black solid), and bayhead tree island (black dashed) 
Figure II.8: Soil nitrogen content with position along survey transects for hardwood hammocks (grey dotted), cypress dome (grey solid), pineland (black solid), and bayhead tree island (black dashed).

Figure II.9: Leaf (solid fill) and soil (open fill) nitrogen content in cypress dome (A), pineland (B), bayhead tree island (C), and hardwood hammock (D) community plots after 21 years (2014) of recovery post Hurricane Andrew compared to initial average plot damage (1993).

Figure II.10: Comparison of soil and leaf nutrient content in pineland (grey filled), cypress dome (grey open), hardwood hammock (black filled), and bayhead tree island (black open) community plots after 21 years (2014) of recovery post Hurricane Andrew....

Figure III.1: Upper: Overview of geographic location of all 12 field sites within Everglades National Park. Lower: Specific community positions along Main Park Road. 76

Figure III.2: Diagram of the $5 \mathrm{~m}$ x 5m survey plots for bayhead tree islands, cypress domes, and hardwood hammocks, and 10m x 20m survey plots and their orientation along transects within a community, including groupings of survey plots for analysis .77

Figure III.3: Individual species loss or gain by plot in each of the four communities in the long-term recovery (20 years) post Hurricane Andrew.....

Figure III.4: Number of individuals in each size class (diameter at breast height size, dbh) during pre-hurricane (1993, black diamonds), short-term recovery (1996, light grey squares), and long-term recovery (2012-13, dark grey triangles)

Figure III.5: Change in species richness within four forest communities compared to the percent of individuals damaged within each plot...

Figure IV.1: Upper: Overview of Geographic location of all 12 field sites within Everglades National Park. Lower: Specific community positions along Main Park Road.

Figure IV.2: Diagram of the $5 \mathrm{~m}$ x $5 \mathrm{~m}$ survey plots for bayhead tree islands, cypress domes, and hardwood hammocks, and 10m x 20m survey plots and their orientation along transects within a community, including groupings of survey plots for analysis .105

Figure IV.3: Difference between actual individual sizes after 19 years (2012-13) and predicted M2 model size for all species included in model performance testing grouped by the target individual's initial size (1993) 
Figure IV.4: Difference between actual individual sizes after 19 years (2012-13) and predicted M2 model size for individuals within each of the four study communities grouped by the target individual's initial size (1993)....

Figure IV.5: Difference between actual individual sizes after 19 years (2012-13) and predicted M2 model size for all hardwood hammock species included in model performance testing grouped by the target individual's initial size (1993)

Figure IV.6: Difference between actual individual sizes after 19 years (2012-13) and predicted M2 model size for Taxodium distichum included in model performance testing.

Figure IV.7: Difference between actual individual sizes after 19 years (2012-13) and predicted M2 model size for Taxodium distichum based on individual position within the cypress dome included in model performance testing....................110

Figure V.1: Conceptual design of the experimental set up with the four factorial treatments (top row) and simulated hurricane treatment (bottom row)

Figure V.2: Tree species seedling shoot weekly growth rates according to high nutrient/high light (HNHL), low nutrient/high light (LNHL), high nutrient/low light (HNLL), and low nutrient/low light (LNLL).

Figure V.3: Tree species seedling shoot weekly growth rates for pre-hurricane treatment and post-hurricane simulation treatment, with hurricane simulation treatment indicated by vertical dashed line.

Figure V.4: Tree species seedling photosynthesis rates according to high nutrient/high light (HNHL), low nutrient/high light (LNHL), high nutrient/low light (HNLL), and low nutrient/low light (LNLL).

Figure V.5: Tree species seedling photosynthesis rates according to low nutrient/low light (LNLL) and post-hurricane simulation treatments

Figure V.6: Images of seedling size after 16 weeks of treatment with high nutrient/high light (HNHL), low nutrient/high light (LNHL), high nutrient/low light (HNLL), and low nutrient/low light (LNLL)

Figure VI.1: Flowchart describing field and shadehouse components of the project and the relation of these components to the main research questions and findings.....148 


\section{I: Introduction and Background}

Hurricanes are a periodically occurring phenomenon in many coastal, low-latitude regions of the world, including the South Florida Everglades. Many plant communities in these regions have traits that allow them to persist in the face of these disturbances (Gunderson 2000). These traits effectively increase community resilience to hurricane impacts. Resilience here is defined as the return time to a stable condition following a disturbance (Gunderson 2000). The possibility of alterations in periodicity and severity of hurricanes in the face of climate change could jeopardize the persistence of these ecosystems through increased precipitation, increased wind speeds, and impressive overall destructive capability (Bender et al. 2010; Emanuel 2005; Grinsted et al. 2013; Goldenberg et al. 2001; Knutson and Tuleya 2004). Strong storms coupled with anthropogenic disturbances could critically threaten hurricane-susceptible ecosystems to an unprecedented level (Bell and Lovelock 2013; Engle 2011; Gedan et al. 2011).

Widespread forest devastation is characteristic of hurricane impacts (Figure I.1; Boose et al. 1994; Stanturf et al. 2007; Zimmerman et al. 1994). How individual plants and communities respond to this type of periodic impact, both in terms of damage susceptibility and regeneration, is key to the recovery of the system. Hurricanes and their impacts are unique, often leaving an "impact fingerprint” on the landscape (Smith et al. 2009). Through time, hurricane impacts collectively form a distinct matrix of heterogeneous landscape effects in the Everglades and across Florida (Doyle 2009). The length of time plant communities need to recover from these effects is uncertain as each community responds to storm impact in various ways and to different degrees. Hurricane 
damage can be variable within a community, as plant type, age, size, and neighboring trees may play a role in how they are affected and in their subsequent response. For example, tall mature trees are more severely damaged by strong winds and lightning, while small trees and understory plants are likely to be sheltered from the damages caused by wind and lightning (Gilliam et al. 2006; Smith et al. 2009; Zhang et al. 2008). In some cases understory plants are damaged at higher rates than canopy trees as a result of falling debris from canopy-level trees (Navarro-Martinez et al. 2012). Damaged trees adjacent to large undamaged trees may be unable to respond because of shading. While overall mortality is low in the canopy, there can be a loss of rare species within the affected communities (Whigham et al. 1991; Vandecar et al. 2011).

The heterogeneity of damage from hurricane impacts results in variation in environmental conditions (i.e., light availability, relative humidity, and soil moisture) across the landscape. Defoliation opens forest canopies and increases levels of incoming photosynthetically active radiation (PAR) that fuel photosynthesis and growth (Battaglia et al. 2001; Carlton and Bazzazz 1998; Fernandez and Fetcher 1991). Increases in light levels in the forest understory can in turn lead to increases in air and soil temperatures (Bowden et al. 1993; Woolbright 1991) and decreases in relative humidity within the canopy (Woolbright 1991). Soil moisture also decreases with decreased relative humidity and increased air and soil temperatures (Battaglia et al. 2001; Guzman-Grajales and Walker 1991). Coupled with a sudden input of litter, increased soil temperature can cause soil microbial activity to increase and thus release of nutrients by decomposition and effluxes of carbon and other greenhouse gases (Bowden et al. 1993; Harmon et al. 1995; Carlton and Bazzazz 1998; Xu et al. 2004). These alterations to the physical 
environment within a forest can increase the ability of new shade-intolerant recruits to become established, but the litter from canopy defoliation can provide microenvironments that aid late-successional, shade tolerant species to become established (Battaglia et al. 2001; Guzman-Grajales and Walker 1991).

Changes in the microenvironment can facilitate regeneration of the forest canopy. Most individuals within the canopy level suffer at least some level of damage, from uprooting, trunk breaking off, stem breakage and defoliation (Van Bloem et al. 2005; Whigham et al. 1991; Whigham et al. 2003). Defoliation drastically increases the amount light available in the canopy and understory. Defoliation also results in large amounts of litter deposited on the forest floor and decomposition of this litter results in a pulse of nutrients (Harmon et al. 1995; Lodge et al. 1991; Ostertag et al. 2003; Xu et al. 2004). The intensity and heterogeneity of these nutrient pulses can have large effects on individuals and the community as a whole (Everham and Brokaw 1996; Yang et al. 2008).

Plants in the Everglades vary in their tolerance to drought, high soil moisture, ground water level, and duration of inundation (hydroperiod) that determine the spatial distribution of vegetation throughout the Everglades region (Jones et al. 2006, Menges and Marks 2008; Stoffella et al. 2010). Soil moisture and inundation in the region can be greatly affected by hurricanes. For example, high water levels can have very negative effects on flooding intolerant species such as those in hardwood hammocks (Jones et al. 2006). The subtropical climate of South Florida is defined by a distinct seasonality in annual precipitation that shifts between winter (dry) and summer (wet) (Mulholland et al. 
1997), and thus some species have adapted by seasonally changing the source of the water they utilize. In the wet season, some plants have adapted to use local soil moisture primarily supplied by precipitation for transpiration, while during the dry season, the same plants tap into regional groundwater (Saha et al. 2010). Species that are vulnerable to moisture fluctuations are unable to survive these changes. (Larsen and Harvey 2011). Taxodium distichum dominate cypress dome communities because they are able to establish in and tolerate long hydroperiods that exclude other woody species (Duever et al. 1986).

Cypress dome communities are dominated by a single species (Taxodium distichum var. nutans) and are relatively resistant to the damaging effects of hurricanes, with mortality of damaged trees being relatively low (Whelan 1997, Noel et al. 1995). Non-canopy species such as epiphytes are shown to be highly damaged from hurricanes but their communities recover (Oberbauer et al. 1996). Large trees are more likely to be damaged as a result of storm impacts. (Whelan 1997). Toppling of tall trees in cypress domes can be beneficial to the community because it allows for regeneration of the canopy by new recruits (Duever et al. 1986).

Pineland communities in the Everglades are dominated by a single species (Pinus elliottii var. densa) and this dominance is maintained primarily by periodic fire disturbance (Gunderson 1994). Mechanical damage as a result of hurricanes in pinelands often impacts most of the individual trees in the community, but overall community mortality is relatively low (Armentano et al. 1995). Human influences are a threat because they typically dissect large pineland stands, thereby leaving the smaller 
segmented tracts vulnerable, because smaller tracts usually experience higher mortality after hurricanes (Armentano et al. 1995).

Intact hardwood hammocks that are dominated by native species are more resistant to hurricane damage compared to the open canopies of disturbed hammocks because of a decreased effect of wind shear (Duever et al. 1986; Horvitz et al. 1995). Hurricanes have been shown to damage the majority of stems in hammocks, but the overall community mortality of canopy species is low (Armentano et al. 1995; Slater et al. 1995). One concern for hammocks that are located in disturbed areas is that any canopy opening can provide an opportunity for invasive species to become established, increasing the chances of loss of rare species (Horvitz et al. 1995; Vandecar et al. 2011).

Hurricane damage in tree islands can range from relatively low (i.e., defoliation and minor branch damage) in short-statured islands to more severe (i.e., trunk damage and toppling) in tall-statured islands (Ugarte et al. 2006). Similar to hardwood hammocks, tree island communities are also susceptible to invasion by exotic species in new canopy openings (Ugarte et al. 2006).

Community resilience is described as the capacity of an ecosystem to respond to a disturbance and return to a steady state (Holling 1973). The idea of resilience lends itself well to the study of hurricane disturbances in the Everglades and the subsequent recoveries of resident communities. Gap formation through damage of canopy species can vastly alter the community makeup in the short term, replacing a relatively smaller number of mature trees with many more seedlings and saplings. The early community composition response is often brief, as stem density has been shown to decline in the first 
several years after a major disturbance (Brokaw 1985; Lewis and Banner-Martin 2012). Gehring et al. (2005) showed that tropical forests were able to recover their community biomass and composition back to conditions similar to pre-disturbance values in 25 years after slash-and-burn agriculture impact. Community resilience to disturbances does not happen in a vacuum, however, as often there are inherent conditions and outside pressures that affect community recovery (Chazdon 2003).

Regeneration of forests after a disturbance, such as hurricane damage, depends on the diversity present within the community at the time of impact (Thompson et al. 2009). Small canopy gaps promote infilling from established trees at gap edges, while larger gaps facilitate the germination of new seedlings that will grow into the canopy (Dickinson et al. 2000; Tanner et al. 1991). However small gaps can help seedling establishment by forming a seedling bank that is able to respond to the next disturbance. This infilling shortly after storm impact indicates that forest regeneration is dominated by established tree species and that the community can recover very quickly if the disturbance is small. The resilience of forest communities to larger disturbances is also dependent on diversity because when forests are impacted by larger disturbances, seedling recruits will grow to recolonize the canopy. High species diversity in the forest allow more sites within the heterogeneous landscape of the gap to be colonized, ultimately leading to a similar species composition to that of the pre-disturbed site (Thompson et al. 2009; Zimmerman et al. 1994). Deposition of litter and its resulting nutrient pulse can be several times larger than the background input from litterfall (Harmon et al. 1995; Lodge et al. 1996; Whigham et al. 1991; Xu et al. 2004). Surviving 
individuals have been shown to quickly respond and reincorporate this increased availability of nutrients to help facilitate their recovery (Ostertag et al. 2003; Scatena et al. 1996).

Outside pressures may alter the trajectory of a community's regeneration after the impact of a hurricane. Newly opened areas could be colonized by exotic species and diseases that alter both the structure and function of the forest (Bodle et al. 1994). One example of this is Laurel Wilt, which has spread throughout the Everglades region and caused large mortality rates within red bay (Persea borbonia) and swamp bay (Persea palustris) over the past decade (Rodgers et al. 2014). These changes in trajectory could give way to a different steady state for the forest (Everham and Brokaw 1996; Gunderson 2000). Knowing both the short- and long-term successional trajectories and resilience of Everglades forest communities to the impacts of hurricane damage is crucial to understanding their stability in the future.

Hurricane Andrew made landfall August 24 ${ }^{\text {th }}, 1992$ on the eastern coast of South Florida near the city of Homestead (Figure I.2). Strong winds and heavy rain associated with Andrew devastated the cities of Homestead and Florida City before tracking northwest across the Everglades National Park (ENP) (Figure I.3). To document the effects of this damage on plant communities within ENP the Hurricane Andrew Recovery Team (HART) project was formed in 1993. The project focused on four community types within the ENP: pinelands, hardwood hammocks, bayhead tree islands, and cypress domes. While not of large areal extent, these communities play key roles in the Everglades system as diversity hot spots and wildlife habitat, and they differ strongly in 
terms of canopy species diversity, susceptibility to wind damage, and recovery patterns. Over three years (1993-96) the team of researchers monitored community composition and function of three sites within each of the four community types. In addition to monitoring community attributes, researchers also assessed damage extent and recovery in all individuals present at the time of Andrew's landfall.

The present dissertation project is a continuation of the HART monitoring of Andrew impact in ENP. The overall objective of this project was to understand the patterns, pace, and mechanisms of the 20+ year recovery process to Hurricane Andrew damage of four Everglade forest communities. This objective was accomplished by evaluating historical plot information and recent plot resurveys in combination with an experimental comparison of the growth and physiological responses of the dominant species of these communities to light and nutrient differences that simulated pre- and post-hurricane conditions (Figure I.4). Outcomes of this study include descriptions of shifts in community structure and function over varying temporal scales of recovery (Chapter II), quantification of changes in community composition (Chapter III), understanding of the differences between responses of communities dominated by single species compared to responses of more diverse communities, and a model of long-term canopy-level individual growth using visual assessment data (Chapter IV). The addition of the shadehouse experiment (Chapter V) I will show the ways in which dominant species seedlings respond to varying environmental conditions and a hurricane simulation, which will elucidate the respective abilities of each species to recolonize the canopy. The following chapters are written in a format to be stand-alone manuscripts, 
each being unique in its findings; however because of this format, some overlap of information is unavoidable. Each of the main chapters (II, III, IV, and V) are formatted to the instructions associated with the journal Ecology.

\section{I.2: References}

Armentano, T V, R F Doren, W J Platt, T Mullins. (1995). "Effects of Hurricane Andrew on Coastal and Interior Forests of Southern Florida: Overview and Synthesis.” Journal of Coastal Research. 21.

Battaglia, L. L., S. A. Fore, R. R. Sharitz. (2001). "Seedling emergence, survival and size in relation to light and water availability in two bottomland hardwood species." Journal of Ecology. 88(6):1041-1050.

Bell, J. and C. E. Lovelock. (2013). "Insuring mangrove forests for their role in mitigating coastal erosion and storm-surge: An Australian case study.” Wetlands. 33:379-389.

Bender, M. A., T. R. Knutson, R E Tuleya, J J Sirutis, G A Vecchi, S T Garner, I M Held. (2010). "Modeled Impact of Anthropogenic Warming on the Frequency of Intense Atlantic Hurricanes.” Science. 327(5964):454-458.

Bodle, M. J., A. P. Ferriter, D. D. Thayer. (1994). "The biology, distribution, and ecological consequences of Melaleuca Quinquenervia in the Everglades.” Everglades:The Ecosystem and Its Restoration. S. M. Davis and J. C. Ogden eds. CRC Press.

Boose, E. R., D. R. Foster, M Fluet. (1994). "Hurricane impacts to tropical and temperate forest landscapes.” Ecological Monographs. 64: 369-400.

Bowden, R. D., M. S. Castro, J. M. Melillo, P. A. Steudler, J. D. Aber. (1993). "Fluxes of greenhouse gases between soil and the atmosphere in a temperate forest following a simulated hurricane blowdown.” Biogeochemistry 21: 61-71.

Brokaw, N. V. L. (1985). “Gap-Phase Regeneration in a Tropical Forest.” Ecology 66:682-687.

Carlton, G. C. and F. A. Bazzaz. (1998). "Resource Congruence and Forest Regeneration Following an Experimental Hurricane Blowdown.” Ecology 79:1305-1319.

Chazdon, R. L. (2003). "Tropical forest recovery: legacies of human impact and natural disturbances.” Perspectives in Plant Ecology, Evolution and Systematics. 6(1-2):51-71. 
Dickinson, M. B., D. F. Whigham, S. M . Hermann. (2000). "Tree regeneration in felling and natural treefall disturbances in a semideciduous tropical forest in Mexico.” Forest Ecology and Management 134(1-3):137-151.

Doyle, T. W., K. W. Krauss, C. J. Wells. (2009). "Landscape Analysis and Pattern of Hurricane Impact and Circulation on Mangrove Forests of the Everglades." Wetlands 29(1): 44-53.

Duever, M J. (1986) “The Big Cypress National Preserve”. National Audubon Society.

Emanuel, K. (2005). "Increasing destructiveness of tropical cyclones over the past 30 years." Nature 436(7051): 686-688.

Engle, V. D. (2011). "Estimating the provision of ecosystem services by Gulf of Mexico Ecosystem Wetlands”. Wetlands. 31:179-193.

Everham, E. M. and N. V. L. Brokaw. (1996) "Forest damage and recovery from catastrophic wind.” Botanical Review. 62(2): 113-185.

Fernandez, D.S. and N. Fetcher. (1991). "Changes in Light Availability Following Hurricane Hugo in a Subtropical Montane Forest in Puerto Rico.” Biotropica 23(4a): 393-399.

Gedan, K. B., M. I. Kirwin, E. Wolanski, E. B. Barbier, B. R. Silliman. (2011). “The present and future role of coastal wetland vegetation in protecting shorelines: answering recent challenges to the paradigm.” Climate Change. 106: 7-29.

Gehring, C., M. Denich, P. L. G. Viek. (2005). "Resiliency of secondary forest regrowth after slash-and-burn agriculture in central Amazonia.” Journal of Tropical Biology 21(5):519-527.

Gilliam, F. S., W. J. Platt, R. K. Peet (2006). "Natural disturbances and the physiognomy of pine savannas: A phenomenological model." Applied Vegetation Science 9(1): 83-96.

Goldenberg, S. B., C. W. Landsea, A. M. Mestas-Nuñez, W. M. Gray. (2001). "The recent increase in Atlantic hurricane activity: Causes and implications." Science 293(5529): 474-479.

Grinsted, A., J. C. Moore. (2013). "Projected Atlantic hurricane surge threat from rising temperatures.” PNAS. 110(14):5369-5373.

Gunderson, L. H. (1994). "Vegetation of the Everglades: Determinants of Community Composition.” Everglades:The Ecosystem and Its Restoration. S. M. Davis and J. C. Ogden eds. CRC Press. 
Gunderson, L. H. (2000). “Ecological Resilience: In Theory and Application.” Annual Review of Ecology and Systematics 31: 425-439.

Guzman-Grajales, S. M. and L. R. Walker. (1991). "Differential Seedling Responses to Litter After Hurricane Hugo in the Luquillo Experimental Forest, Puerto Rico.” Biotropica 23(4a):407-413.

Harmon, M. E., D. F. Whigham, J. Sexton, I. Olmsted. (1995). "Decomposition and mass of woody detritus in the tropical dry forests of the northeastern Yucatan Peninsula, Mexico.” Biotropica. 27(3):305-316.

Holling, C. S. (1973). "Resilience and Stability of Ecological Systems.” Annual Review of Ecology and Systematics 4:1-23.

Horvitz, C C, S McMann, A Freedman. 1995. "Exotics and Hurricane Damage in Three Hardwood Hammocks in Dade County Parks, Florida”. Journal of Coastal

Research.21:145-158.

Jones, D.T., J.P. Sah, M. S. Ross, S. F. Oberbauer, B. Hwang, K. Jayachandran. (2006). "Growth and physiological responses of twelve tree species common to Everglades tree islands to simulated hydrologic regimes." Wetlands 26:830-844.

Knutson, T. R. and R. E. Tuleya (2004). "Impact of CO2-induced warming on simulated hurricane intensity and precipitation: Sensitivity to the choice of climate model and convective parameterization." Journal of Climate 17(18): 3477-3495.

Larsen, L. G. and J. W. Harvey (2011). "Modeling of hydroecological feedbacks predicts distinct classes of landscape pattern, process, and restoration potential in shallow aquatic ecosystems." Geomorphology 126(3-4): 279-296.

Lewis, R. J. and K. H. Bannar-Martin. (2012). "The Impact of Cyclone Fanele on a Tropical Dry Forest in Madagascar.” Biotropica. 44(2):135-140.

Lodge, D. J., F. N. Scatena, C. E. Asbury, M. J. Sanchez. (1991). "Fine Litterfall and Related Nutrient Inputs Resulting from Hurricane Hugo in Subtropical Wet and Lower Montane Rain Forests in Puerto Rico.” Biotropica. 23(4a):336-342.

Mulholland, P.J., Best, G.R., C. C. Coutant, G. M. Hornberger, J. L. Meyer, P. J. Robinson, J. R. Stenberg, R. E. Turner, F. R. Vera-Herrera, R. G. Wetzel. (1997) Effects of climate change on freshwater systems of the south-eastern United States and the Gulf coast of Mexico. Hydrological Processes.11.

Navarro-Martinez, A., R. Duran-Garcia, M. Mendez-Gonzalez . (2012) “The impact of Hurricane Dean on the structure and arboreal composition of a managed forest in Quintana Roo, Mexico.” Madera Y Bosques. 18(1):57-76. 
Noel, J M, A Maxwell, W. J. Platt, L. Pace. (1995). "Effects of Hurricane Andrew on Cypress (Taxodium distichum var. nutans) in South Florida.” Journal of Coastal Research. 12.

Oberbauer, S. F., K. von Kleist, K. R. T. Whelan, S. Koptur. (1996). “Effects of Hurricane Andrew on epiphyte communities within cypress domes of Everglades National Park.” Ecology 77(3): 964-967.

Ostertag, R., F. N. Scatena, W. L. Silver. (2003). "Forest floor decomposition following hurricane litter inputs in several Puerto Rican forests.” Ecosystems. 6(3):261-273.

Rodgers, L., Derksen, A., \& Pernas, T. (2014).” Expansion and impact of laurel wilt in the Florida Everglades” Florida Entomologist. 97(3): 1247-1250.

Saha, A. K., O. Leonel da Silveira, M. S. Ross, F. Miralles-Wilhelm. (2010). "Water source utilization and foliar nutrient status differs between upland and flooded plant communities in wetland tree islands." Wetlands Ecology and Management 18(3): 343355.

Scatena, F. N., S. Moya, C. Estrada, J. D. Chinea. (1996). “The First Five Years in the Reorganization of Aboveground Biomass and Nutrient Use Following Hurricane Hugo in the Bisley Experimental Watersheds, Luquillo Experimental Forest, Puerto Rico.” Biotropica. 28(4a):424-440.

Slater, H H, W J Platt, D. B. Baker, H. A. Johnson. (1995). "Effects of Hurricane Andrew on Damage and Mortality of Trees in Subtropical Hardwood Hammocks of Long Pine Key, Everglades National Park, Florida, USA.” Journal of Coastal Research. 21.

Smith, T. J., G. H. Anderson, K. Balentine, G. Tiling, G. A. Ward, K. R. T. Whelan. (2009). "Cumulative Impacts of Hurricanes on Florida Mangroves Ecosystems: Sediment Deposition, Storm Surges and Vegetation." Wetlands 29(1): 24-34.

Stanturf, J. A., S. L. Goodrick, K. W. Outcalt. (2007). "Disturbance and coastal forests: A strategic approach to forest management in hurricane impact zones.” Forest Ecology and Management. 250(1-2):119-135.

Tanner, E. V. J., and V. Kapos. (1991).”Hurricane Effects on Forest Ecosystems in the Caribbean.” Biotopica. 23(4a):513-521.

Thompson, I., Mackey, B., McNulty, S., Mosseler, A. (2009). "Forest Resilience, Biodiversity, and Climate Change. A synthesis of the biodiversity/resilience/stability relationship in forest ecosystems.” Secretariat of the Convention on Biological Diversity, Montreal. Technical Series no. 43, 67 pages. 
Ugarte, C A, L A Brandt, S. Melvin, F. J. Mazzotti, K. G. Rice. (2006). "Hurricane Impacts to Tree Islands in Arthur R. Marshall Loxahatchee National Wildlife Refuge, Florida.” Southeastern Naturalist. 5 (4).

Van Bloem, S. J., P. G. Murphy, A. E. Lugo, R. Ostertag. (2005). “The Influence of Hurricane Winds on Caribbean Dry Forest Structure and Nutrient Pools." Biotropica. 37(4):571-583.

Vandecar, K. L., D. Lawrence, D. Richards, L. Schneider, J. Rogan, B. Schmook, H. Wilbur. (2011). "High Mortality for Rare Species Following Hurricane Disturbance in the Southern Yucatan.” Biotropica. 43(6):676-684.

Whelan, K R T. 1997 "Short Term Response of Two Cypress Communities Within Everglades National Park To The Effects of Hurricane Andrew”. Masters Thesis. Florida International University.

Whigham, D. F., I. Omsted, E. C. Cano, A. B. Curtis. (2003). "Impacts of hurricanes on the forests of Quintana Roo, Yucatan Peninsula, Mexico." The lowland Maya: three millennia at the human-wildland interface. Haworth Press, Binghamton: 193-216.

Whigham, D. F., I. Olmsted, E. C. Cano, M. E. Harmon. (1991). “The impact of Hurricane Gilbert on trees, litterfall, and woody debris in a in a dry tropical forest in the northeastern Yucatan Peninsula.” Biotropica. 23(4):434-441.

Woolbright, L. L. (1991). "The Impact of Hurricane Hugo on Forest Frogs in Puerto Rico.” Biotropica 23(4a):462-467.

Xu, X. N., E. Hirata, H. Shibata. (2004). "Effect of typhoon disturbance on fine litterfall and related nutrient input in a subtropical forest on Okinawa Island., Japan.” Basic and Applied Ecology. 5(3):271-282.

Yang, L. H., J. L. Bastow, K. O. Spence, A. N. Wright. (2008). "What we can learn from nutrient pulses.” Ecology. 89(3):621-634.

Zhang, K. Q., M. Simard, M. Ross, V. H. Rivera-Monroy, P. Houle, P. Ruiz, R. R. Twilley, K. R. T. Whelan. (2008). "Airborne laser scanning quantification of disturbances from hurricanes and lightning strikes to mangrove forests in Everglades National Park, USA." Sensors 8(4): 2262-2292.

Zimmerman, J. K., E. M. Everham III, R. B. Waide, D. J. Lodge, C. M. Taylor, N. V. Brokaw.(1994). "Responses of tree species to hurricane wind in subtropical wet forest in Puerto Rico Implications for tropical tree life histories.” Journal of Ecology. 82(4):911-922. 


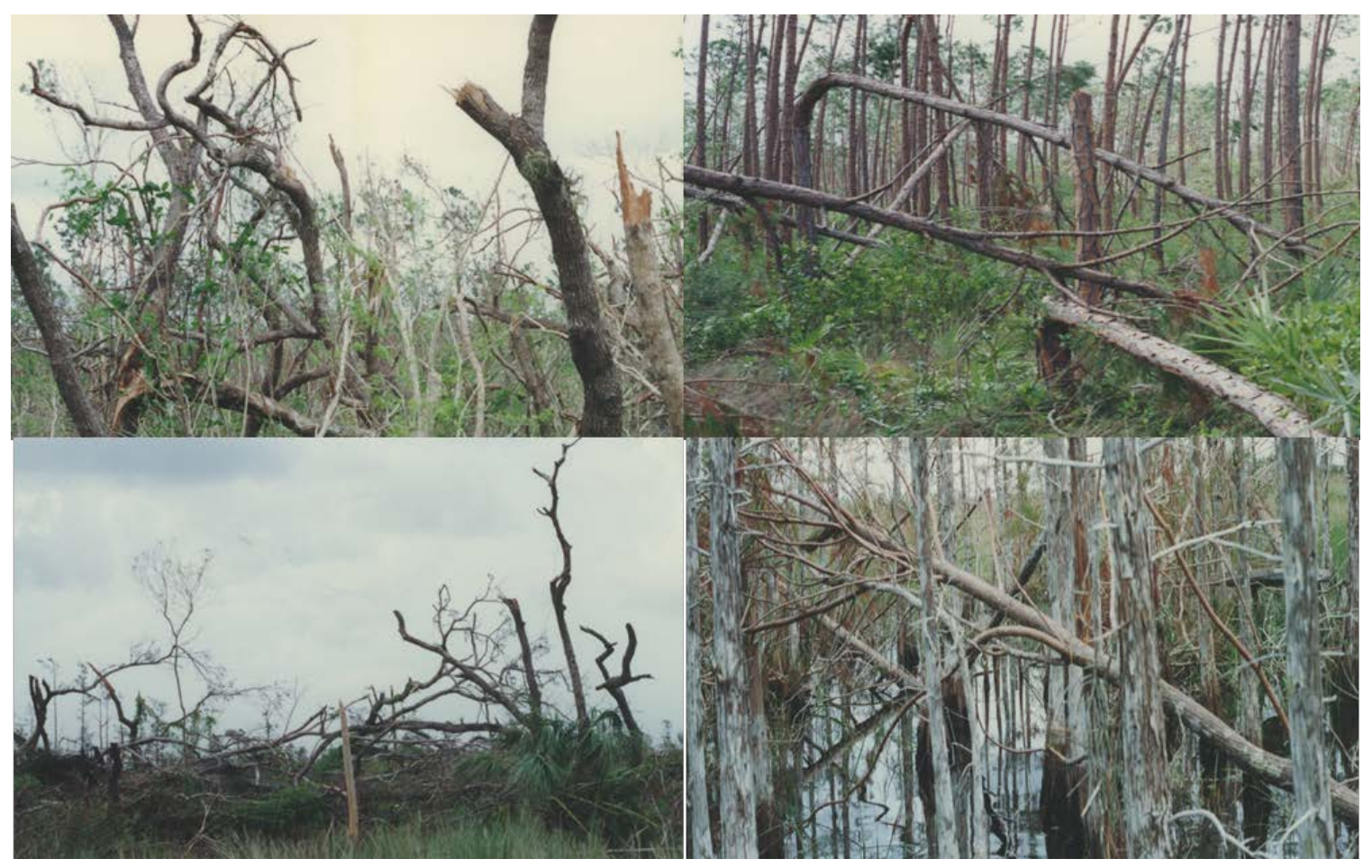

Figure I.1: Examples of Hurricane Andrew damage in Everglades National Park forest communities (circa 1992). Upper left= hardwood hammock, upper right= pineland, lower left=bayhead tree island, lower right= cypress dome. 


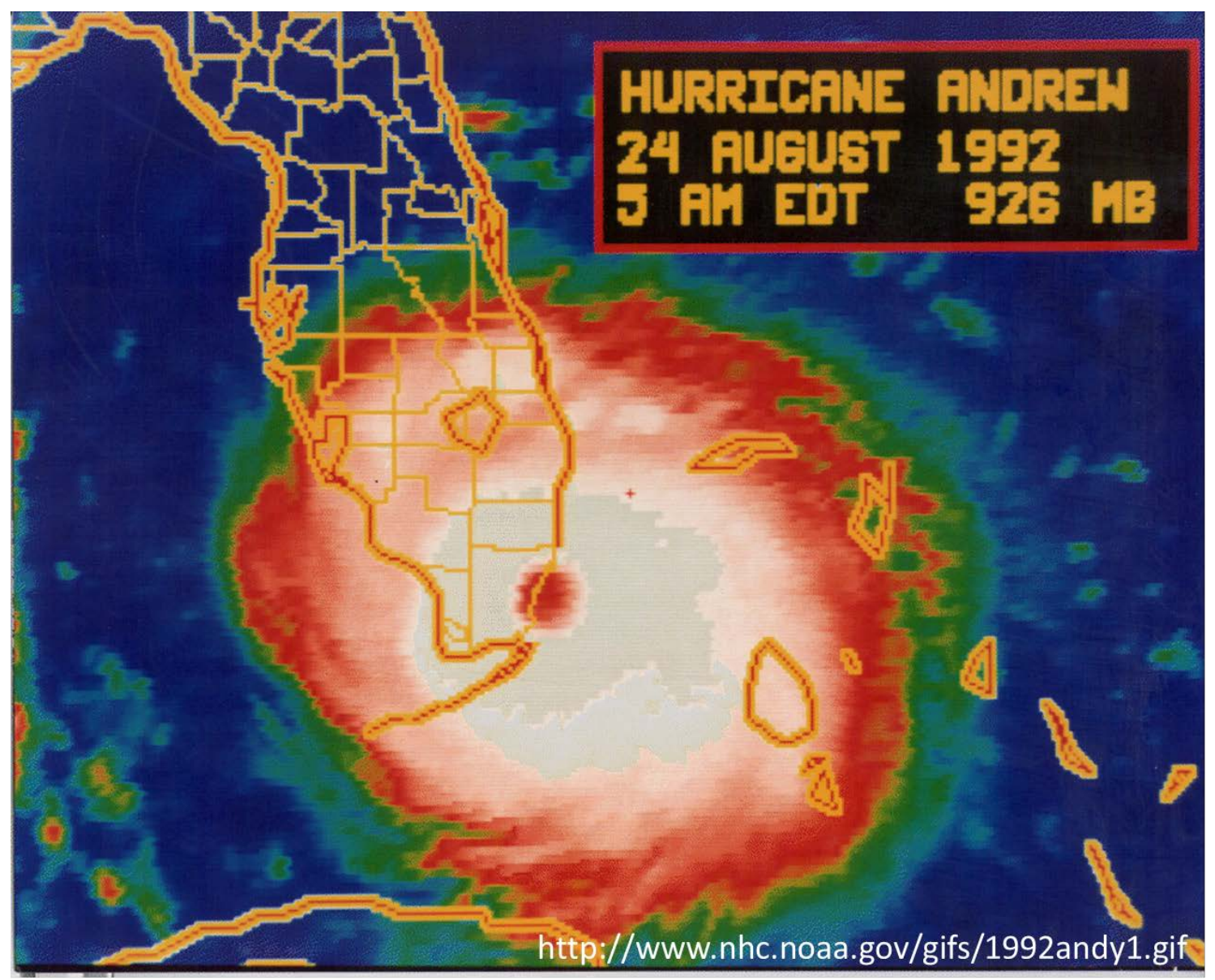

Figure I.2: Infrared image of Hurricane Andrew eye-wall landfall August 24, 1992 (National Oceanographic and Atmospheric Administration). 


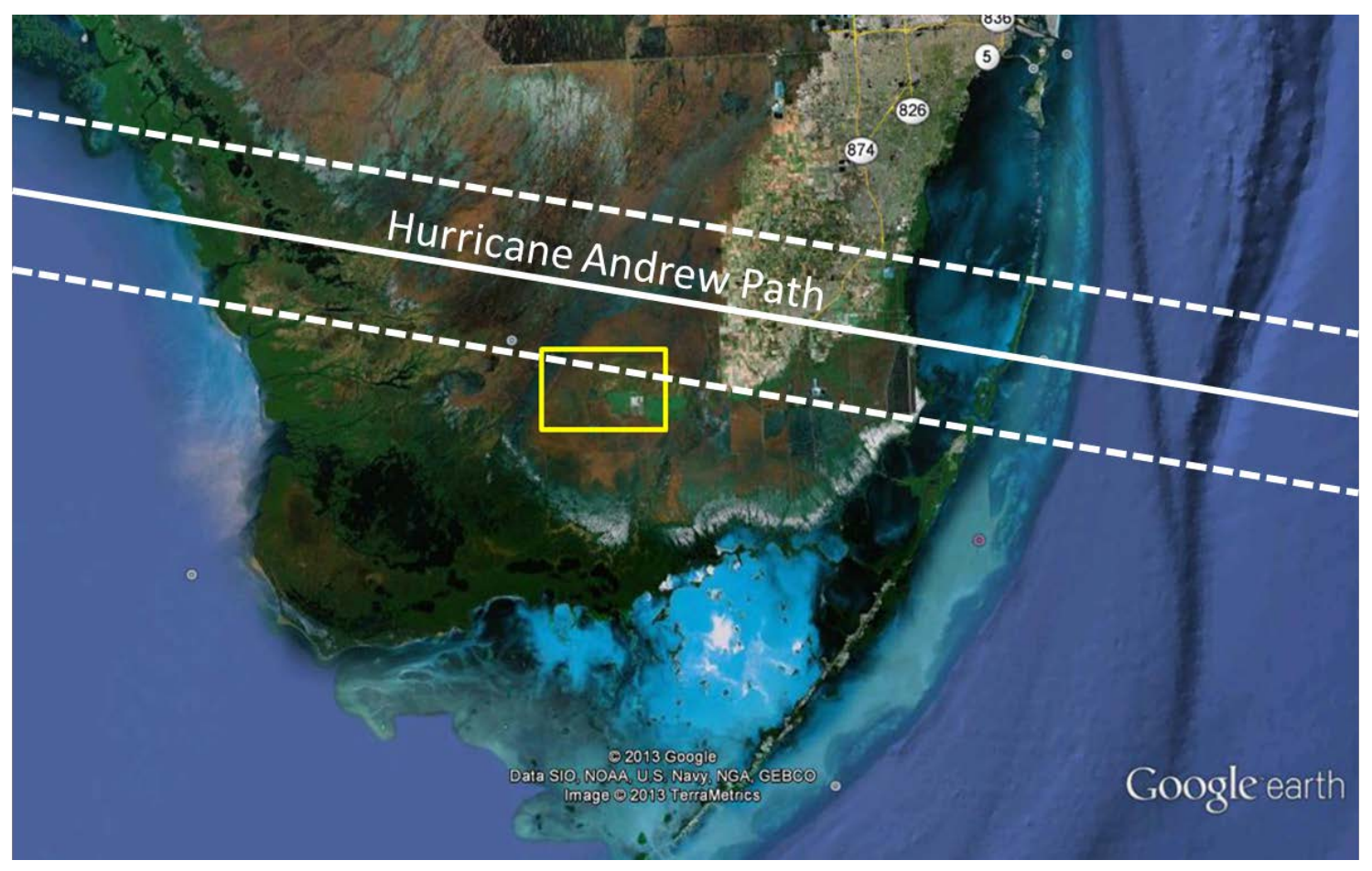

Figure I.3: Geographic track of Hurricane Andrew eye center (solid line) and eye-wall edge (dashed lines) across South Florida. Rectangular box outlines position of study sites with Everglades National Park. 


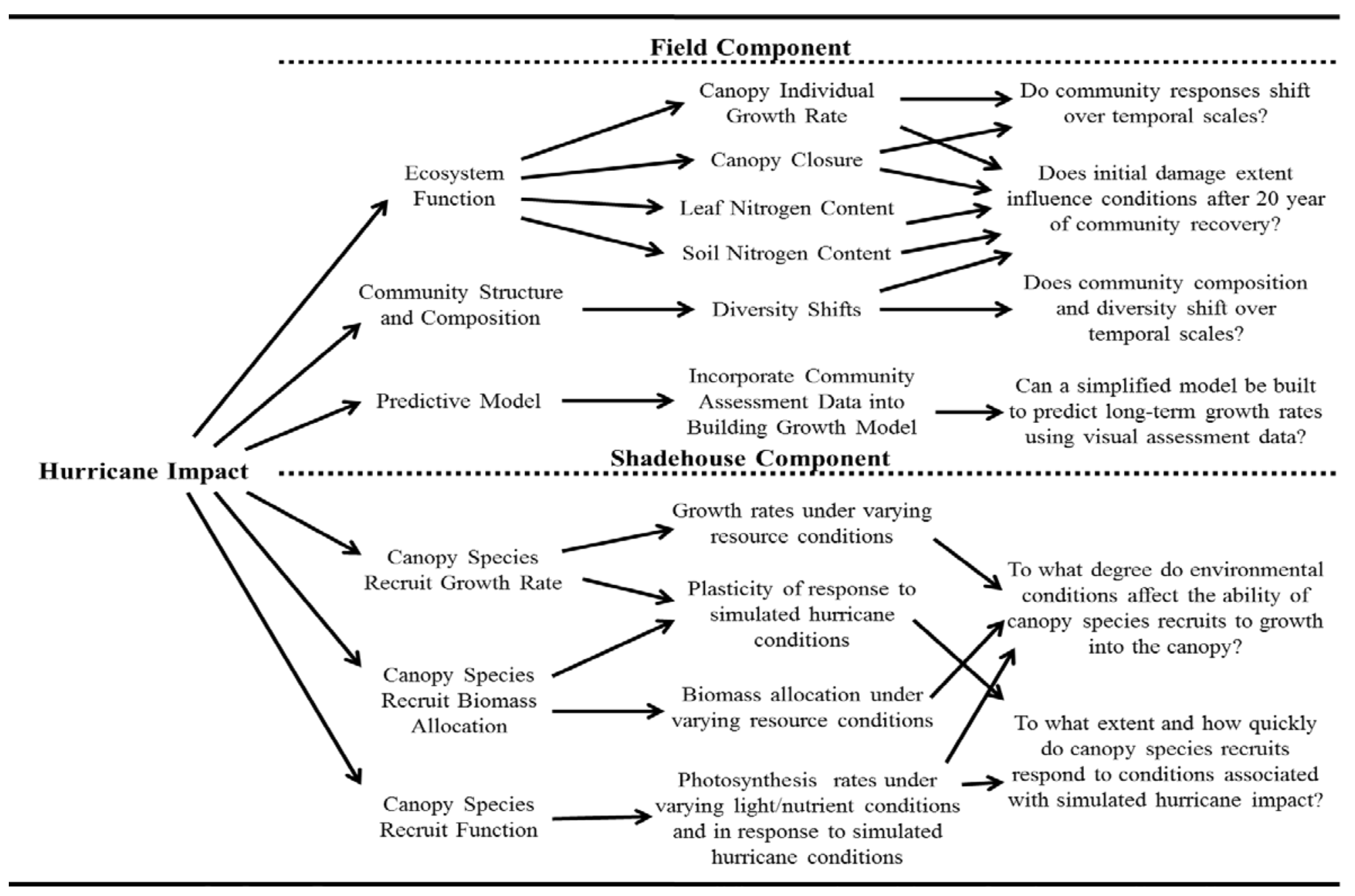

Figure I.4: Flowchart describing field and shadehouse components of the project and the relation of these components to the main research questions. 
II: Temporal Changes in Community Structure and Function Following Hurricane Andrew Impact in Four Non-Tidal Forest Communities in the Florida Everglades

\section{II.1: Abstract}

Hurricanes are large scale, periodic disturbances that affect many plant

communities in low latitude regions of the world. Hurricane Andrew was a category five hurricane that made landfall in South Florida on August $24^{\text {th }} 1992$. Andrew caused widespread devastation to the South Florida region, including the Florida Everglades. Here I investigate the effects of hurricane damage on four, non-tidal, forest communities within the Everglades National Park (ENP) as a continuation of the Hurricane Andrew Recovery Team (HART) research. The HART assessed pineland, hardwood hammock, bayhead tree island, and cypress dome communities in ENP for community composition, damage, and recovery beginning in 1993, along with short-term recovery surveys conducted yearly until 1996. Long-term recovery surveys were conducted in 2012 and 2014-15 to monitor soil and leaf nitrogen content, canopy closure, and individual tree growth rates. Canopy openness shortly after the hurricane impact showed large levels of defoliation (20-42\% cover), closing over the short-term recovery period (31-82\% cover), and remaining fairly steady through the long-term recovery period (36-87\% cover). Soil and leaf nitrogen content levels were community-specific; however, there were very few perceptible residual effects from hurricane damage over the long-term recovery period. Growth rates of most canopy species were higher in the three years after hurricane impact with rates slowing over the long-term recovery period. Additional monthly growth rate monitoring with dendrometers showed that peak growth rates of dominant species coincided with peak hurricane season, highlighting vulnerability to storm impacts on 
growth. Additionally, community structure and function in all four target communities showed that they returned to near steady state conditions within a few years after storm impact.

\section{II.2: Introduction}

Tropical storms are large, periodic disturbances that are important factors in shaping many forests around the world. This is particularly true in low latitude regions of the world, including forest communities within the South Florida Everglades. The Everglades system is situated at a unique position at the juncture of geographic range limits for temperate and tropical plant species (Gunderson 1994). The unique community composition provides insight into how communities may be altered in other areas as a result of climate change and how they will respond to hurricane disturbance. Many studies have investigated the recovery of hurricane-impacted forest communities over short-term time periods; however few investigated more long-term temporal shifts in recovery. Here to understand the pace and pattern of recovery post-hurricane, I report how growth and structure of four Everglades forest communities have responded to Hurricane Andrew over a 20-year time period.

Tropical storm damage is often widespread across susceptible regions and can have devastating impacts on plant communities across the landscape (Boose et al. 1994; Zimmerman et al. 1994; Stanturf et al. 2007). Despite storm damage being widespread, the impact is often heterogeneous in severity with damage levels being influenced by community structure and composition (Doyle 2009). Within each community, heterogeneity of impact affected trees of differing sizes, ages, and spatial arrangements to 
varying degrees (Gilliam et al. 2006; Lewis and Banner-Martin 2012; Navarro -Martinez et al. 2012). Trees that occupy the highest levels of a canopy often suffer higher damage levels from wind and rain exposure, compared to those that occupy sub-canopy and understory areas (Whelan 1997; Platt et al. 2000; Platt et al. 2002). Stem and canopy density also affect the level of damage sustained within a community, as intact and more dense canopy communities are sheltered and receive low levels of individual-level damage (Duever et al. 1986; Armentano et al. 1995; Horvitz et al. 1995).

Initial damage is influenced by the nature of the canopy at the time of the storm, while the intensity and duration of the storm also influence how much damage the canopy receives. Despite damage heterogeneity across community types, almost all canopy and sub-canopy individuals receive some damage (Whigham et al. 1991; Whigham et al. 2003; Van Bloem et al. 2005). Although taller, canopy level individuals often receive the most damage, sub-canopy and understory individuals often receive some damage as a result of falling debris (Van Bloem et al. 2005; Duever et al. 1986). Traditionally, mortality in all levels of the canopy is low in the short-term recovery time period with most individuals quickly refoliating and recolonizing the canopy level space (Whigham et al. 1991; Vandecar et al. 2001). Increases in damage extent and severity can also lead to a dissected canopy (Beckage et al. 2006). Canopy defoliation and branch damage during a storm have the potential to shift environmental conditions for the individuals in these communities.

Canopy damage can vary widely across community type and structure, although all canopies experience some level of defoliation. Defoliation as a result of high winds 
has immediate effects on canopy and understory environmental conditions. Canopy opening increases the amount of incoming solar and photosynthetically active radiation that is available to individuals in the affected community (Fernandez and Fetcher 1991; Oberbauer et al. 1996; Battaglia et al. 2001; Robertson and Platt 2001). Storm-related defoliation causes green, nutrient rich litter to quickly accumulate in the understory, often resulting in a pulse of nutrients that becomes available to resident plants (Bowden et al. 1993; Harmon et al. 1995; Xu et al 2004). Changes in the availability of nutrients can alter resource pooling in individuals (Dawson et al 2002) and the ability of those individuals to recover from damage (Monnier et al 2013).

After the immediate impact of a storm has subsided, the shifts in environmental conditions can influence plant growth rates for several years into the recovery period. Individuals that survive storm damage often quickly respond to these new conditions, although not all species respond in the same manner and extent (Scatena et al. 1996; Ostertag et al. 2003; Yang et al. 2008). Across most species examined, increased growth rates follow increases in available light and nutrients present in communities (Everham and Brokaw 1996; Grubb et al. 1996; Denslow et al. 1998; Rodriguez-Garcia and Bravo 2013). Species-specific responses to fluctuations in available resources have the potential to shift community composition and structure over time.

Here, I compare the short- and long-term impacts of hurricane damage on the structure and function of four forest communities in the Everglades National Park (ENP). Specifically, I investigated forest canopy closure, individual tree growth rates, and soil/leaf nitrogen content over spatial and temporal scales. Growth rates (measured by diameter at breast height (dbh)) were expected to be lower over the long-term recovery 
period (2012-14) compared to initial growth rates shortly following Hurricane Andrew. Monthly growth rates (measured by dendrometers) were expected to follow the seasonal precipitation shifts of the region. Post-hurricane the canopy closed quickly with canopy light conditions become similar to those of background undisturbed conditions. Leaf and soil nitrogen content were expected to be similar in plots that suffered mild and severe damage, with no perceptible difference between plots after long-term recovery. Overall, the effects of Hurricane Andrew were expected to be minimally perceptible over the long-term time scale compared to that of the short-term.

\section{II.3: Methods}

Study sites were established in 1993 shortly after landfall of Hurricane Andrew as part of the Hurricane Andrew Recovery Team (HART) project within the Everglades National Park in southern Florida (Figure II.1). Community types selected within the study system were pineland, tropical hardwood hammock, bayhead tree island, and cypress domes. Three sites were selected within each community type to provide replication (12 total sites). Within each of the sites a 100m transect, or the length of the study community if less than 100m in longest dimension, was established. Along each transect 5m x 5m survey plots for hardwood hammocks, bayhead tree islands and cypress domes, and 10m x 20m survey plots for pinelands were established at intervals of $10 \mathrm{~m}$ on alternating sides of the transect (Figure II.2).

Initial surveys (1993) assessed each individual tree for size (diameter at breast, dbh), species community makeup, canopy cover and visual assessment of damage category associated with the storm (Table II.1). Subsequent resurveys were conducted in 
1996, 2012-2013, and 2014 to assess growth, mortality and individual recovery in the short- (1996) and long-term (2012-13 and 2014) recovery periods. During the subsequent surveys, growth was assessed by measuring diameter at breast height of permanently marked individuals 1994, 1996, 2012-13 and 2014. Monthly canopy tree growth rates were measured using dendrometers (Felker and Diaz-De Leon 2005) installed on a subset of dominant species individuals (approximately 20 in each site) and monitored every month for one year (Worbes 1995). Four species were selected for dendrometer, monthly growth rate monitoring: Quercus virginiana (bayhead tree islands and hardwood hammocks), Bursera simaruba (bayhead tree islands and hardwood hammocks), Pinus elliottii (pinelands), and Taxodium distichum (cypress domes).

Recovery of ecosystem canopy structure was assessed throughout the study by measuring canopy closure post hurricane. Canopy cover was estimated by sunfleck ceptometer (Decagon Devices 1987) and fisheye photography (Johnson and Vogel 1968; Lemmon 1956), depending on the sampling year. Sunfleck ceptometer measurements were used to determine canopy cover during the initial surveys (1993-1996) and fisheye photography was used in the later surveys (2012). Fisheye photography images were analyzed using Gap Light Analyzer (GLA, Cary Institute of Ecosystem Studies, Millbrook, New York, USA) to determine percent canopy openness.

During the 2014 survey, leaf and soil samples were collected from the center of each survey plot, in order to minimize plot edge effects. One soil sample was collected from each plot to a depth of $10 \mathrm{~cm}$ (or less where the soil layer was less than $10 \mathrm{~cm}$ ). Leaf samples were collected from Taxodium distichum (cypress dome), Pinus elliottii 
(pineland), and Quercus virginiana (hardwood hammock and bayhead tree island). Soil and leaf samples were dried for 48 hours at $60^{\circ} \mathrm{C}$ before nutrient and isotope analysis using a Thermo Scientific Finnigan Delta-C Elemental Analyzer (Thermo Fisher Scientific, Waltham, Massachusetts, USA) at the Florida International University Stable Isotope Lab.

Yearly growth rates were analyzed using one-way analysis of variance to determine shifts in growth between initial- (1993-96), intermediate- (1996-2012), and long-term (2012-14) time scales. A correlation analysis was performed to determine the relationship between canopy closure (all communities combined and individually), plot soil nitrogen content, and leaf nitrogen content of target species compared with average plot-level damage at the time of initial survey (1993). All statistical tests were performed using the R statistical environment (R Foundation for Statistical Computing, Vienna, Austria).

\section{II.4: Results}

Yearly growth rates were species-specific across varying temporal and spatial scales during the survey period post Hurricane Andrew (Table II.2). Across all communities 30 species maintained enough individuals for growth rates to be accurately monitored over the length of the study. Of the 30 species monitored, eight of the species decreased in growth rates after the initial recover time post hurricane Andrew (1993-96) and only one species increased. Bumelia salicifolia was the only species to decrease growth rate over time in the bayhead tree island (1993-96:0.598cm dbh year-1 $2012-$ 14:0.324cm dbh year ${ }^{-1}, \mathrm{p}=0.020$ ). Pinus elliottii was the only species monitored in the 
pineland community, and it did not change growth rate over time. In cypress domes, Ficus spp (1993-96:0.167cm dbh year ${ }^{-1}$, 2012-14:0.064cm dbh year ${ }^{-1}$, p<0.001), Salix

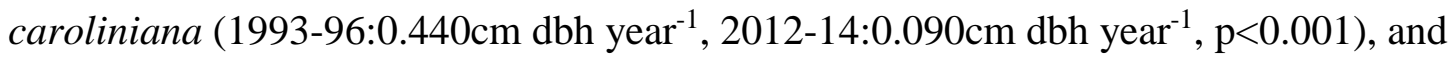
Taxodium distichum (1993-96:0.266 cm dbh year ${ }^{-1}, 2012-14: 0.111 \mathrm{~cm} \mathrm{dbh}$ year ${ }^{-1}$, $\mathrm{p}=0.035$ ) all decreased growth rates over time in the recovery period. Hardwood hammock communities had three species that decreased growth rate over time; Ardisia escallonioides (1993-96:0.331 cm dbh year ${ }^{-1}$, 2012-14:0.047cm dbh year ${ }^{-1}, \mathrm{p}<0.001$ ), Bursera simaruba (1993-96:0.324cm dbh year ${ }^{-1}, 2012-14: 0.124 \mathrm{~cm}$ dbh year $\left.{ }^{-1}, \mathrm{p}=0.002\right)$, and Guettarda scabra (1993-96:0.202cm dbh year-1 , 2012-14:0.040 cm dbh year-1, $\mathrm{p}<0.001)$. Across all communities only Ilex cassine in the hardwood hammocks increased growth rate as the community recovered (1993-96:0.023cm dbh year-1 ${ }^{-1}$,2012-14:0.142cm dbh year $\left.{ }^{-1}, p<0.001\right)$. All growth rate shifts occurred during the intermediate time period of the study (1996-2012).

All four dominant canopy species that were monitored for monthly growth rates followed a trend of maximum monthly growth during the summer months, June through September (wet season, Figure II.3). Taxodium distichum, in the cypress dome communities, had the most pronounced shift between winter $\left(0.000-0.011 \mathrm{~cm}\right.$ dbh month ${ }^{-}$ ${ }^{1}$ ) and summer growth $\left(0.012-0.023 \mathrm{~cm} \mathrm{dbh}\right.$ month $\left.^{-1}\right)$. Overall, $P$. elliottii had the lowest growth rates throughout the year of all the monitored species $\left(0.003-0.019 \mathrm{~cm} \mathrm{dbh}_{\mathrm{month}}\right.$ $\left.{ }^{1}\right)$. Quercus virginiana and Bursera simaruba followed similar patterns regardless of community type, although Q. virginiana grew fastest in bayhead tree islands (0.015- 
$\left.0.026 \mathrm{~cm} \mathrm{dbh} \mathrm{month}{ }^{-1}\right)$ and B. simaruba fastest in hardwood hammocks $(0.013-0.024 \mathrm{~cm}$ dbh month $\left.{ }^{-1}\right)$.

Canopy cover for pinelands, cypress domes, and hardwood hammocks all increased shortly after Hurricane Andrew, quickly returning (3 years post-hurricane) to conditions similar to initial conditions after 20 years (Figure II.4). Hardwood hammock canopies were opened the most as a result of storm defoliation. Hardwood hammock canopies closed the fastest of all the community types (1993:35\% to 1995:82\%) and did not change over the long-term (2014: 82\%). Pinelands and cypress domes both close after Andrew over the short-term period (1993:20\% to $1995: 31 \%$ and $1993: 42 \%$ to $1995: 53 \%$, respectively), however they continued to close over the long-term (2014: 36\% and 67\% respectively). After the long-term recovery period (2014), bayhead tree island and hardwood hammock communities had the highest levels of canopy closure (2014: 6286\% and 53-87\% respectively) and pinelands had the lowest (Figure II.5). Pinelands had the most open canopies and were the most consistent along the length of each study transect (2014: 36-47\%). Cypress domes had consistent canopy cover throughout most of the transect lengths, however each showed more openness around the center of the dome. Canopy closure was not assessed in bayhead tree island communities over the short-term recovery period and thus was not included in this analysis.

A comparison of canopy closure and average plot damage at the time of initial survey (1993) showed varying levels of correlation by community type over the longterm community recovery time period (2014). Cypress dome $\left(\mathrm{R}^{2}=0.024, \mathrm{p}=0.383\right.$, Figure II.6-A), pineland $\left(R^{2}=0.024\right.$, $p=0.508$, Figure II.6-B), and bayhead tree island $\left(R^{2}=0.005\right.$, 
$\mathrm{p}=0.318$, Figure II.6-C) canopy closure after 21 years was not affected by the initial level of damage. Hardwood hammocks were the only community type to demonstrate a longterm canopy cover correlation with initial plot level damage indicating a negative relationship between damage severity and canopy closure $\left(\mathrm{R}^{2}=0.120, \mathrm{p}=0.042\right.$, Figure II.6-D).

Soil and leaf nitrogen content were varied by specific community type after the long-term recovery period (Table II.3). Taxodium distichum in cypress dome communities had the highest levels of nitrogen in both soil and leaf tissues $(2.50 \%$ and 2.23\%, respectively), while P. elliottii in pineland communities had the lowest soil and leaf nitrogen content (1.40\% and 1.29\%, respectively). Quercus virginiana leaf nitrogen content was the same in both bayhead tree islands and hardwood hammocks (1.61\%), although hardwood hammocks had higher levels of soil nitrogen content $(2.03 \%$ and $1.60 \%$, for hardwood hammocks and tree islands respectively). Leaf nitrogen content was fairly consistent along study transects for hardwood hammocks (1.14-1.89\%), bayhead tree islands (1.11-1.90\%), and pinelands (0.56-1.10\%; Figure II.7). Cypress dome communities had the highest variability in leaf nitrogen content along transects (1.483.48\%). Soil nitrogen content along study transects was more heterogeneous compared to leaf nitrogen content (Figure II.8). Pineland communities had the most consistent nitrogen content across plots and had the lowest nitrogen content compared to other community types (0.40-1.11\%). Cypress dome and hardwood hammock communities had the highest levels of soil nitrogen content, however they were also the most heterogeneous along the transects (1.97-3.17\% and 1.67\%-2.62\% respectively). 
Effects of initial plot level damage on leaf and soil nitrogen content after the longterm recovery period varied by community. Cypress dome soil nitrogen content was not affected by initial plot damage $\left(\mathrm{R}^{2}=0.069, \mathrm{p}=0.141\right)$ although leaf nitrogen content was correlated to damage extent $\left(\mathrm{R}^{2}=0.162, \mathrm{p}=0.040\right.$; Figure II.9-A). Initial plot level damage did not affect leaf or soil nitrogen content for pineland (Leaf $\mathrm{N} \mathrm{R}^{2}=0.058, \mathrm{p}=0.257$, Soil $\mathrm{N} \mathrm{R}^{2}=0.031$, $\mathrm{p}=0.417$; Figure II.9-B), bayhead tree island (Leaf $\mathrm{N} \mathrm{R}^{2}=0.003, \mathrm{p}=0.826$, Soil $\mathrm{N} \mathrm{R}^{2}=0.001$, $\mathrm{p}=0.890$; Figure II.9-C), or hardwood hammock (Leaf $\mathrm{N} \mathrm{R}^{2}=0.032$, $\mathrm{p}=0.316$, Soil $N \mathrm{R}^{2}=0.039, \mathrm{p}=0.141$; Figure II.9-D) communities.

Comparison of soil and leaf nitrogen content revealed a positive correlation across all community types (Figure II.10). Pineland communities had both the lowest soil and leaf nitrogen content of all and cypress domes had the highest. Bayhead tree island and hardwood hammock communities were the only communities that had substantial overlap in both soil and leaf nitrogen content.

\section{II.5: Discussion}

Most of the forest communities shifted their responses to hurricane impacts over the temporal scales of this study. Direct impacts of Hurricane Andrew on the structure and function of these four community types decreased over time; however, the degree and timing of this decrease were often community-specific. Individual species studied also demonstrated unique responses and vulnerabilities in growth rates and to hurricane damage. 
In all communities except cypress domes, there was no perceptible influence of Hurricane Andrew damage extent on soil or leaf nitrogen levels after 20 years of recovery. This is consistent with past studies that have shown nutrient pulses related to storm impact are short lived, and those nutrients are quickly reincorporated into the biomass of surviving individuals (Bowden et al. 1993; Harmon et al. 1995; Xu et al. 2004). Only soil nitrogen levels in cypress domes were correlated with plot level damage extents, and cypress domes also displayed the highest levels of soil nitrogen overall. Higher soil nitrogen levels may be a result of increased nutrient deposition from surface water flow through domes in the wet season and of the dominant tree species, $T$. distichum, dropping leaves during the dry season. Across community types, pinelands were lowest in both soil and leaf nitrogen levels and were also the community type with the shallowest soil layers. Most communities had no detectable differences in soil nitrogen content demonstrated across initial damage extent after 20 years of recovery. Soil and leaf nitrogen levels had the biggest overlap in hardwood hammock and bayhead tree island communities, likely due to similarities in community structure and resident species in both.

Canopy level refoliation was most pronounced over the short-term, presumably as individuals that survived hurricane Andrew took advantage of more favorable growing conditions. Filling in of the canopy occurred over the first three years of recovery, which is consistent with previous studies (Whigham et al. 1991; Vandecar et al. 2001). After the initial three years of canopy recovery and refoliation, there was little continued closing of the canopy over the long-term time period. Most communities, except hardwood 
hammocks, showed no residual impact of initial hurricane damage on canopy closure. Hardwood hammock plots, in contrast, showed that increased hurricane damage levels resulted in a closed canopy after 20 years of recovery. It is notable that plots with higher damage levels had a higher frequency of smaller individuals and stumps of larger individuals compared to plot with less damage, contributing to canopy openness.

Position along the study transects affected canopy closure (sampled during the 20 year recovery period) in communities with distinct variations in community features (e.g. distinct edges and holes in the center of cypress domes). Canopy openness increased as each transect approached the a community edge and was present in all communities, except pinelands, which differed because all transects were positioned within the center of pineland communities. Canopy cover in cypress domes decreased as each transect approached the "hole" in the center of the dome, an area distinguished by open water and few cypress individuals. Beyond these edge and hole-in-the-dome effects, transect position had little impact on heterogeneity of canopy closure.

Monthly growth rates varied by species and community type; however, all growth rates followed a similar seasonal trend. Growth rates were highest during the late summer (wet season) months of June-September and were lowest in winter (dry season) months of December-February. Overall, both conifer species (T. distichum and P. elliottii) grew more slowly than the broadleaf species (Q. virginiana and B. simaruba). Taxodium distichum growth rates were similar to those of the broadleaf species during the summer months. However, yearly growth was limited because of leaf loss during the winter months, resulting in very little or no growth. The tropical species, B. simaruba, showed 
the highest growth rate of all species, and growth was most pronounced in the hardwood hammock communities. The importance of summer growth in all species surveyed revealed the inherent vulnerability of species to hurricane damage. Atlantic hurricane season extends from early June to late November with peak months of possible impacts in August and September. Defoliation and other mechanical damage from such storms that strike during the peak growing season have the potential to dramatically slow growth, with re-allocation of resources to recovery.

Species growth rates varied widely both spatially and temporally in response to Hurricane Andrew. Despite damage received by the majority of individuals across all communities, growth rates were fastest in most species over the three years after storm impact compared to the 20-year period. Faster growth rates of surviving individuals over the short term is consistent with previous findings (Grubb et al. 1996; Scatena et al. 1996; Denslow et al. 1998), although these increased growth rates decreased after initial recovery. Short-term increases in growth rates are likely a result of release by temporary improvement of growing conditions (increased nutrients and incoming solar radiation) and release from direct competition. Short-statured, mid-canopy species, such as Bumelia salicifolia and Ficus spp., showed a contrary trend as growth rates were lower immediately post-Andrew and increased over time. This reversed pattern of growth in mid-canopy species may be a result of adaptations to growth in an intact canopy and thus growth being hindered when the forest canopy is opened by defoliation.

Hurricanes are periodic events that affect wide swaths of the landscape where they alter the way communities are structured and function. I have shown that Hurricane 
Andrew defoliated all of the forest communities in this study and affected the growth rates of the resident species. Despite the immediate impact of the storm, the community recovered almost completely to its original structure and functioning after 20 years with very few residual alterations. Most of the growth of the dominant species occurs during the wet season, summer months, timing that implies an inherent vulnerability of these species to hurricanes, whose probability of impact also peaks during these same months. Increases in the frequency ( $<20$ years) and/or strength of hurricanes in the region may threaten the ability of these forest communities to fully recover before being impacted again.

\section{II.6: References}

Armentano, T V, R F Doren, W. J. Platt, T. Mullins. (1995). "Effects of Hurricane Andrew on Coastal and Interior Forests of Southern Florida: Overview and Synthesis." Journal of Coastal Research. 21.

Battaglia, L. L., S. A. Fore, R. R. Sharitz. (2001). "Seedling emergence, survival and size in relation to light and water availability in two bottomland hardwood species." Journal of Ecology. 88(6):1041-1050.

Beckage, B., L. J. Gross, W. J. Platt. (2006). "Modelling responses of pine savannas to climate change and large-scale disturbance." Applied Vegetation Science 9(1): 75-82.

Boose, E. R., D. R. Foster, M. Fluet. (1994). "Hurricane impacts to tropical and temperate forest landscapes.” Ecological Monographs. 64: 369-400.

Bowden, R. D., M. S. Castro, J. M. Melillo, P. A. Steudler, J. D. Aber. (1993). "Fluxes of greenhouse gases between soil and the atmosphere in a temperate forest following a simulated hurricane blowdown.” Biogeochemistry 21: 61-71.

Dawson, T. E., S. Mambelli, A. H. Plamboeck, P. H. Templer, K. P. Tu. 2002. "Stable isotopes in plant ecology." Annual Review of Ecological Systems. 33:507-559.

Denslow J. S., A. M. Ellison, R. E. Sanford. (1998). "Treefall gap size effects on aboveand below-ground processes in a tropical wet forest.” Journal of Ecology 86(4): 597-609. 
Doyle, T. W., K. W. Krauss, C. J. Wells (2009). "Landscape Analysis and Pattern of Hurricane Impact and Circulation on Mangrove Forests of the Everglades." Wetlands 29(1): 44-53.

Duever, M. J. (1986) “The Big Cypress National Preserve.” National Audubon Society.

Everham, E. M. and N. V. L. Brokaw. (1996) “Forest damage and recovery from catastrophic wind.” Botanical Review. 62(2): 113-185.

Fernandez, D.S. and N. Fetcher. (1991). “Changes in Light Availability Following Hurricane Hugo in a Subtropical Montane Forest in Puerto Rico.” Biotropica 23(4a): 393-399.

Gilliam, F. S., W. J. Platt, R. K. Peet. (2006). "Natural disturbances and the physiognomy of pine savannas: A phenomenological model." Applied Vegetation Science 9(1): 83-96.

Grubb, P. J., W. G. Lee, J. Kollman, J. B. Wilson. (1996). “Interaction of irradiance and soil nutrient supply on growth of seedlings of ten European tall-shrub species and Fagus sylvatica.” Journal of Ecology. 84:827-840.

Gunderson, L. H. (1994). "Vegetation of the Everglades: Determinants of Community Composition.” Everglades:The Ecosystem and Its Restoration. S. M. Davis and J. C. Ogden eds. CRC Press.

Harmon, M. E., D. F. Whigham, J. Sexton, I. Olmsted. (1995). “Decomposition and mass of woody detritus in the tropical dry forests of the northeastern Yucatan Peninsula, Mexico.” Biotropica. 27(3):305-316.

Horvitz, C C, S McMann, A Freedman. 1995. "Exotics and Hurricane Damage in Three Hardwood Hammocks in Dade County Parks, Florida.” Journal of Coastal Research.21:145-158.

Lewis, R. J. and K. H. Bannar-Martin. (2012). "The Impact of Cyclone Fanele on a Tropical Dry Forest in Madagascar.” Biotropica. 44(2):135-140.

Monnier, Y., A. Bousquet-Melou, B. Vila, B. Prévosto, C. Fernandez. (2013) “How nutrient availability influences acclimation to shade of two (pioneer and latesuccessional) Mediterranean tree species?” European Journal of Forest Restoration. 132:325-333.

Navarro-Martinez, A., R. Duran-Garcia, M. Mendez-Gonzalez. (2012) “The impact of Hurricane Dean on the structure and arboreal composition of a managed forest in Quintana Roo, Mexico.” Madera Y Bosques. 18(1):57-76. 
Oberbauer, S. F., K. von Kleist, K. R. T. Whelan, S. Koptur. (1996). "Effects of Hurricane Andrew on epiphyte communities within cypress domes of Everglades National Park.” Ecology 77(3): 964-967.

Ostertag, R., F. N. Scatena, W. L. Silver. (2003). "Forest floor decomposition following hurricane litter inputs in several Puerto Rican forests.” Ecosystems. 6(3):261-273.

Platt, W. J., B. Beckage, R. F. Doren, H. H. Slater. (2002). "Interactions of large-scale disturbances: Prior fire regimes and hurricane mortality of savanna pines." Ecology 83(6): 1566-1572.

Platt, W. J., R. F. Doren, T. V. Armentano. (2000). "Effects of Hurricane Andrew on stands of slash pine (Pinus elliottii var. densa) in the everglades region of south Florida (USA)." Plant Ecology 146(1): 43-60.

Robertson, K. M. and W. J. Platt (2001). "Effects of multiple disturbances (fire and hurricane) on epiphyte community dynamics in a subtropical forest, Florida, USA." Biotropica 33(4): 573-582.

Rodriguez-Garcia, E., and F. Bravo. (2013). "Plasticity in Pinus pinaster populations of diverse origins: Comparative seedling responses to light and Nitrogen availability.” Forest Ecology and Management. 307:196-205.

Scatena, F. N., S. Moya, C. Estrada, J. D. Chinea. (1996). "The First Five Years in the Reorganization of Aboveground Biomass and Nutrient Use Following Hurricane Hugo in the Bisley Experimental Watersheds, Luquillo Experimental Forest, Puerto Rico.”

Biotropica. 28(4a):424-440.

Stanturf, J. A., S. L. Goodrick, K. W. Outcalt. (2007). "Disturbance and coastal forests: A strategic approach to forest management in hurricane impact zones." Forest Ecology and Management. 250(1-2):119-135.

Van Bloem, S. J., P. G. Murphy, A. E. Lugo, R. Ostertag, M. R. Costa, I. R. Bernard, S. M. Colon, M. C. Mora. (2005). "The Influence of Hurricane Winds on Caribbean Dry Forest Structure and Nutrient Pools.” Biotropica. 37(4):571-583.

Vandecar, K. L., D. Lawrence, D. Richards, L. Schneider, J. Rogan, B. Schmook, H. Wilbur . (2011). "High Mortality for Rare Species Following Hurricane Disturbance in the Southern Yucatan.” Biotropica. 43(6):676-684.

Whelan, K R T. 1997 "Short Term Response of Two Cypress Communities Within Everglades National Park To The Effects of Hurricane Andrew”. Masters Thesis. Florida International University. 
Whigham, D. F., I. OlmsteI, E. C. Cano, A. B. Curtis. (2003). "Impacts of hurricanes on the forests of Quintana Roo, Yucatan Peninsula, Mexico." The lowland Maya: three millennia at the human-wildland interface. Haworth Press, Binghamton: 193-216.

Whigham, D. F., I. Olmsted, E. C. Cano, M. E. Harmon. (1991). "The impact of Hurricane Gilbert on trees, litterfall, and woody debris in a in a dry tropical forest in the northeastern Yucatan Peninsula.” Biotropica. 23(4):434-441.

Xu, X. N., E. Hirata, H. Shibata. (2004). "Effect of typhoon disturbance on fine litterfall and related nutrient input in a subtropical forest on Okinawa Island., Japan.” Basic and Applied Ecology. 5(3):271-282.

Yang, L. H., J. L. Bastow, K. O. Spence, A. N. Wright. (2008). "What we can learn from nutrient pulses.” Ecology. 89(3):621-634.

Zimmerman, J. K., E. M. Everham III, R. B. Waide, D. J. Lodge, C. M. Taylor, N. V. Brokaw. (1994). "Responses of tree species to hurricane wind in subtropical wet forest in Puerto Rico- Implications for tropical tree life histories.” Journal of Ecology. 82(4):911-922. 
Table II.1: Damage classifications for initial vegetation assessments with number and proportions of affected individuals.

\begin{tabular}{clll}
\hline $\begin{array}{c}\text { Damage } \\
\text { Assessment } \\
\text { Numeric } \\
\text { Category }\end{array}$ & Damage Type & n & \% \\
\hline 0 & No damage & 117 & 7.8 \\
1 & Bent Branches & 78 & 5.2 \\
2 & Minor Branch Damage & 513 & 34.1 \\
3 & Major Branch Damage & 397 & 26.4 \\
4 & Trunk Snap Off & 361 & 24.0 \\
5 & Tip Up & 38 & 2.5 \\
\hline
\end{tabular}


Table II.2: Species yearly growth rates for tagged individuals surviving across the short- (1993-96), intermediate- (1996-12), and long-term time scales for all for study communities. Different letters indicate significantly different growth rates over the three study intervals.

\begin{tabular}{|c|c|c|c|c|c|c|c|c|}
\hline \multicolumn{9}{|c|}{ Yearly Growth Rate (cm dbh/yr'-1) } \\
\hline Species & $\mathbf{n}$ & $\begin{array}{r}1993- \\
1996\end{array}$ & $\mathbf{n}$ & $\begin{array}{r}1996- \\
2012\end{array}$ & & $\mathbf{n}$ & $\begin{array}{r}2012- \\
2014\end{array}$ & \\
\hline \multicolumn{9}{|c|}{ Bayhead Tree Island } \\
\hline Bursera simaruba & 15 & 0.306 & 4 & 0.369 & & 4 & 0.352 & \\
\hline Bumelia salicifolia & 23 & 0.598 & $\mathrm{a}$ & 0.365 & $\mathrm{~b}$ & 6 & 0.324 & $\mathrm{~b}$ \\
\hline Eugenia axillaris & 10 & 0.221 & 1 & 0.226 & & 1 & 0.226 & \\
\hline Ficus spp & 13 & 0.443 & 2 & 0.327 & & 2 & 0.318 & \\
\hline Lysiloma bahamensis & 24 & 0.772 & 5 & 0.642 & & 4 & 0.638 & \\
\hline Metopium toxiferum & 11 & 0.407 & 4 & 0.384 & & 4 & 0.323 & \\
\hline \multicolumn{9}{|c|}{ Pineland } \\
\hline Pinus elliotii & 151 & 0.159 & a 19 & 0.114 & $\mathrm{~b}$ & 19 & 0.103 & C \\
\hline \multicolumn{9}{|c|}{ Cypress Dome } \\
\hline Annona glabra & 2 & 0.120 & 2 & 0.141 & & 2 & 0.121 & \\
\hline Ficus spp & 6 & 0.167 & 3 & 0.054 & $\mathrm{~b}$ & 2 & 0.064 & $\mathrm{~b}$ \\
\hline Myrica cerifera & 6 & 0.300 & 0 & - & & 0 & - & \\
\hline Salix caroliniana & 5 & 0.440 & 3 & 0.085 & $\mathrm{~b}$ & 3 & 0.090 & $\mathrm{~b}$ \\
\hline Taxodium distichum & 826 & 0.266 & a 667 & 0.126 & $\mathrm{~b}$ & 664 & 0.111 & $\mathrm{~b}$ \\
\hline \multicolumn{9}{|c|}{ Hardwood Hammock } \\
\hline Ardisia escallonioides & 21 & 0.331 & a 6 & 0.081 & $\mathrm{~b}$ & 5 & 0.047 & $\mathrm{~b}$ \\
\hline Bursera simaruba & 27 & 0.324 & 17 & 0.221 & $\mathrm{ab}$ & 16 & 0.143 & $\mathrm{~b}$ \\
\hline
\end{tabular}


Table II.2 continued...

\begin{tabular}{|c|c|c|c|c|c|c|c|c|}
\hline \multicolumn{9}{|c|}{ 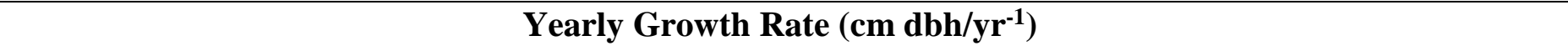 } \\
\hline Species & 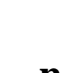 & 1993- & & 1996- & & & 2012- & \\
\hline & $\mathbf{n}$ & & $\mathbf{n}$ & & & $\mathbf{n}$ & & \\
\hline Bumelia salicifolia & 51 & 0.026 & 32 & 0.039 & & 32 & 0.030 & \\
\hline Eugenia axillaris & 64 & 0.160 & 42 & 0.091 & & 42 & 0.077 & \\
\hline Erythrina herbacea & 2 & 0.053 & 1 & 0.032 & & 1 & 0.036 & \\
\hline Exothea paniculata & 11 & 0.148 & 5 & 0.118 & & 4 & 0.089 & \\
\hline Ficus spp & 12 & 0.084 & 6 & 0.109 & & 6 & 0.089 & \\
\hline Guettarda scabra & 6 & 0.202 & 1 & 0.043 & $\mathrm{~b}$ & 1 & 0.040 & $\mathrm{~b}$ \\
\hline Ilex cassine & 13 & 0.023 & 9 & 0.120 & $\mathrm{~b}$ & 7 & 0.142 & $\mathrm{~b}$ \\
\hline Lysiloma bahamensis & 47 & 0.048 & 19 & 0.033 & & 18 & 0.028 & \\
\hline Myricanthes fragrans & 16 & 0.155 & 5 & 0.100 & & 5 & 0.084 & \\
\hline Metopium toxiferum & 13 & 0.160 & 3 & 0.130 & & 3 & 0.097 & \\
\hline Nectandra coriacea & 49 & 0.071 & 10 & 0.091 & & 9 & 0.102 & \\
\hline Persea borbonia & 4 & 0.167 & 3 & 0.092 & & 3 & 0.073 & \\
\hline Prunus myrtifolia & 6 & 0.106 & 4 & 0.082 & & 4 & 0.073 & \\
\hline Quercus virginiana & 24 & 0.223 & 13 & 0.168 & & 13 & 0.158 & \\
\hline Simarouba glauca & 6 & 0.117 & 5 & 0.192 & & 5 & 0.21 & \\
\hline
\end{tabular}


Table II.3: Soil and leaf percent nitrogen content by community type and site.

\begin{tabular}{|c|c|c|c|c|c|}
\hline & & Soil & & Leaf & \\
\hline Community & $\mathrm{n}$ & $\mathrm{N} \%$ & se & $\mathrm{N} \%$ & se \\
\hline Bayhead Tree Island & 21 & 1.60 & 0.06 & 1.61 & 0.05 \\
\hline Bayhead 1 & 7 & 1.47 & 0.08 & 1.49 & 0.09 \\
\hline Bayhead 2 & 7 & 1.67 & 0.07 & 1.67 & 0.02 \\
\hline Bayhead 3 & 7 & 1.66 & 0.02 & 1.66 & 0.06 \\
\hline Pineland & 24 & 1.40 & 0.07 & 1.29 & 0.07 \\
\hline Grimshaw & 12 & 0.74 & 0.07 & 0.71 & 0.03 \\
\hline Pilsbry & 12 & 0.96 & 0.05 & 0.92 & 0.03 \\
\hline Cypress Dome & 31 & 2.50 & 0.09 & 2.23 & 0.14 \\
\hline Far Dome & 8 & 2.58 & 0.05 & 2.90 & 0.20 \\
\hline Cute Dome & 12 & 2.41 & 0.13 & 1.74 & 0.07 \\
\hline Cottonmouth Dome & 11 & 2.53 & 0.09 & 2.05 & 0.15 \\
\hline Hardwood Hammock & 33 & 2.03 & 0.07 & 1.61 & 0.05 \\
\hline Redd & 9 & 2.04 & 0.05 & 1.48 & 0.07 \\
\hline Grimshaw & 12 & 2.14 & 0.11 & 1.69 & 0.04 \\
\hline Pilsbry & 12 & 1.90 & 0.05 & 1.66 & 0.04 \\
\hline
\end{tabular}




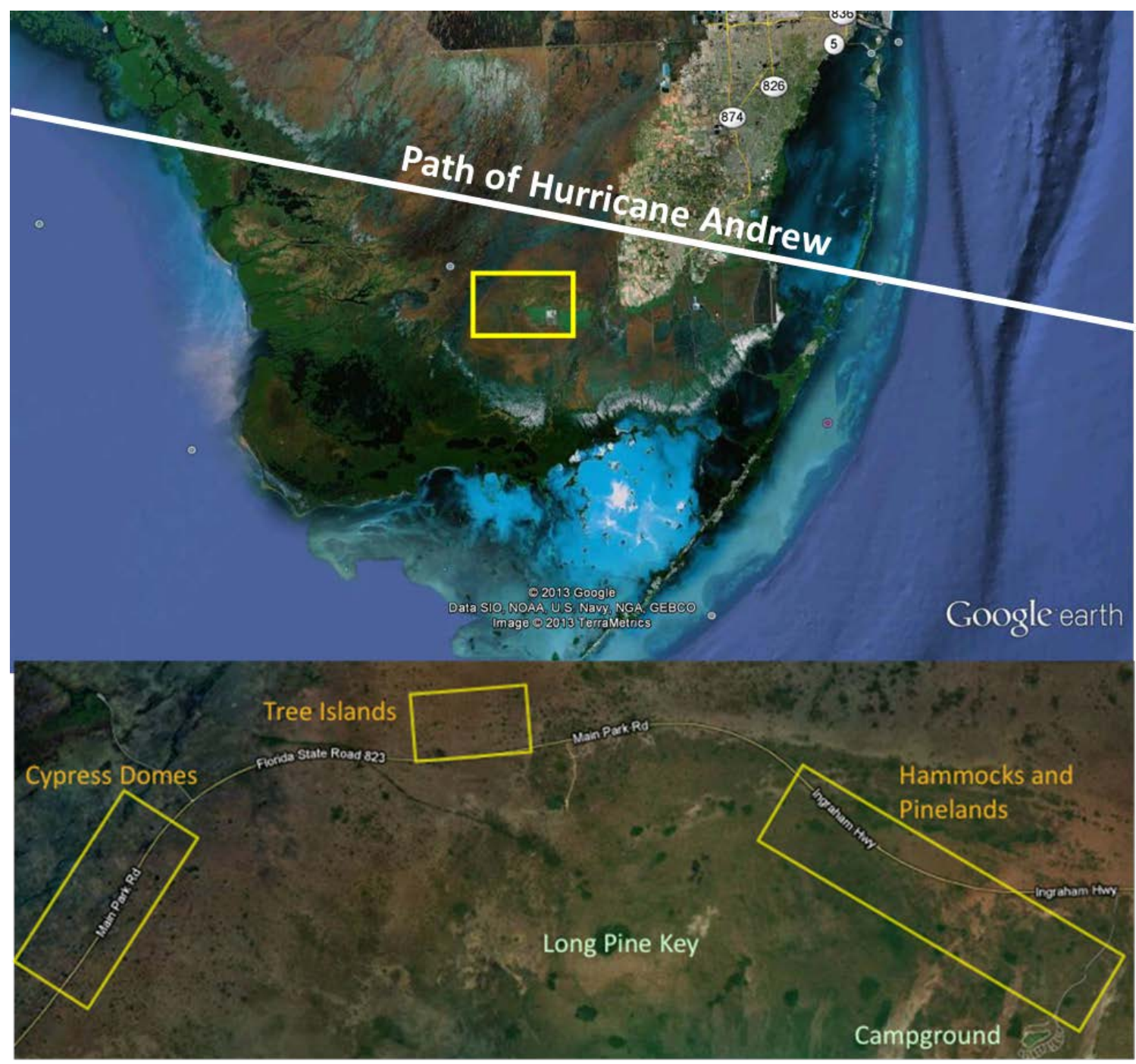

Figure II.1: Upper: Overview of geographic location of all 12 field sites within Everglades National Park. Lower: Specific community positions along Main Park Road 


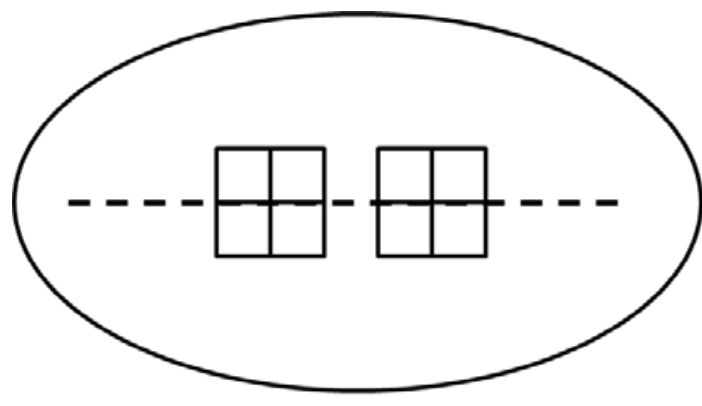

Bayhead Tree Island

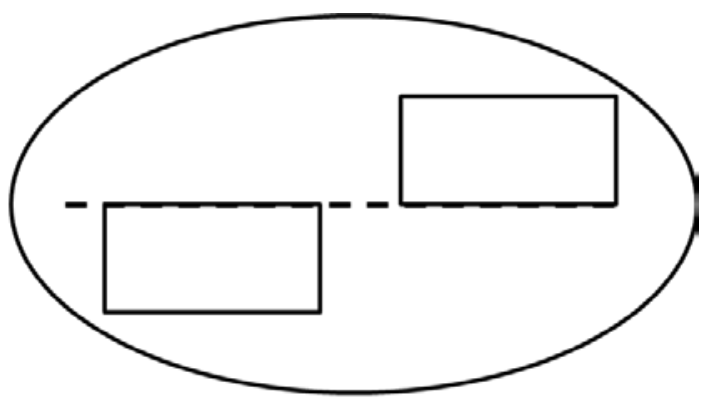

Pineland

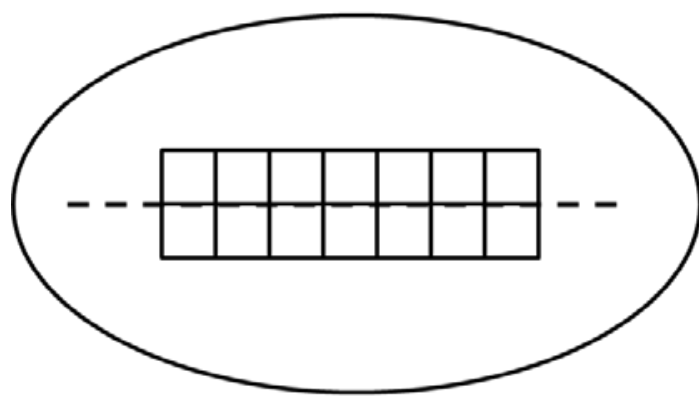

Cypress Dome

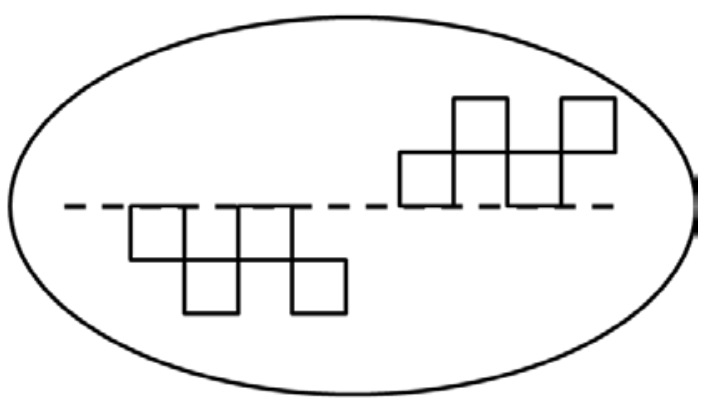

Hardwood Hammock

Figure II.2: Diagram of the $5 \mathrm{~m} x$ $5 \mathrm{~m}$ survey plots for bayhead tree islands, cypress domes, and hardwood hammocks, and $10 \mathrm{~m}$ x 20m survey plots in pinelands and their orientation along transects within a community. 


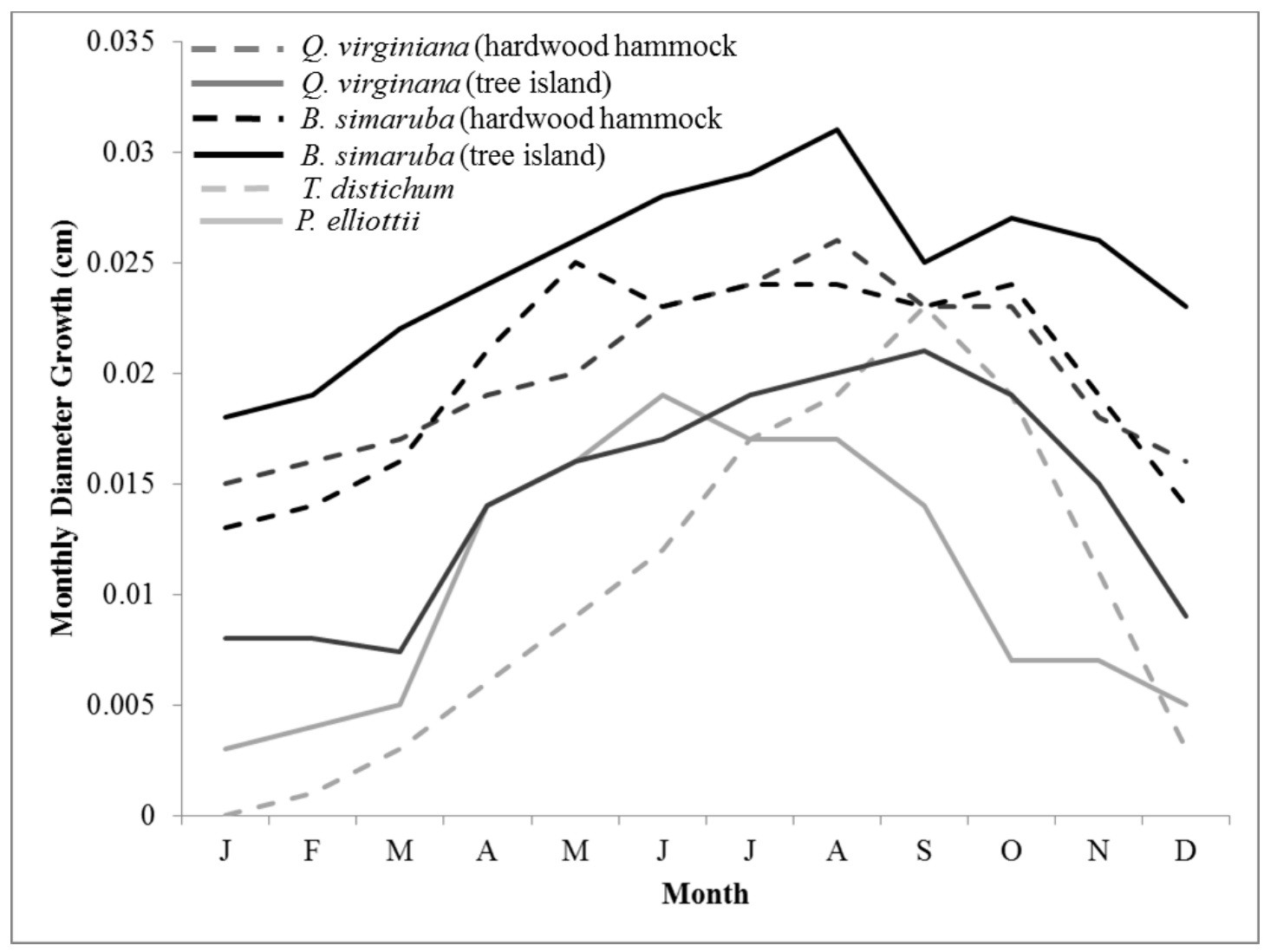

Figure II.3: Monthly growth rates (diameter) of $T$. distichum (light grey dashed), $P$. elliottii (light grey solid), Q. virginiana in hardwood hammocks (dark grey dashed) and bayhead tree islands (dark grey solid), and B. simaruba in hardwood hammocks (black dashed) and bayhead tree islands (black solid). 


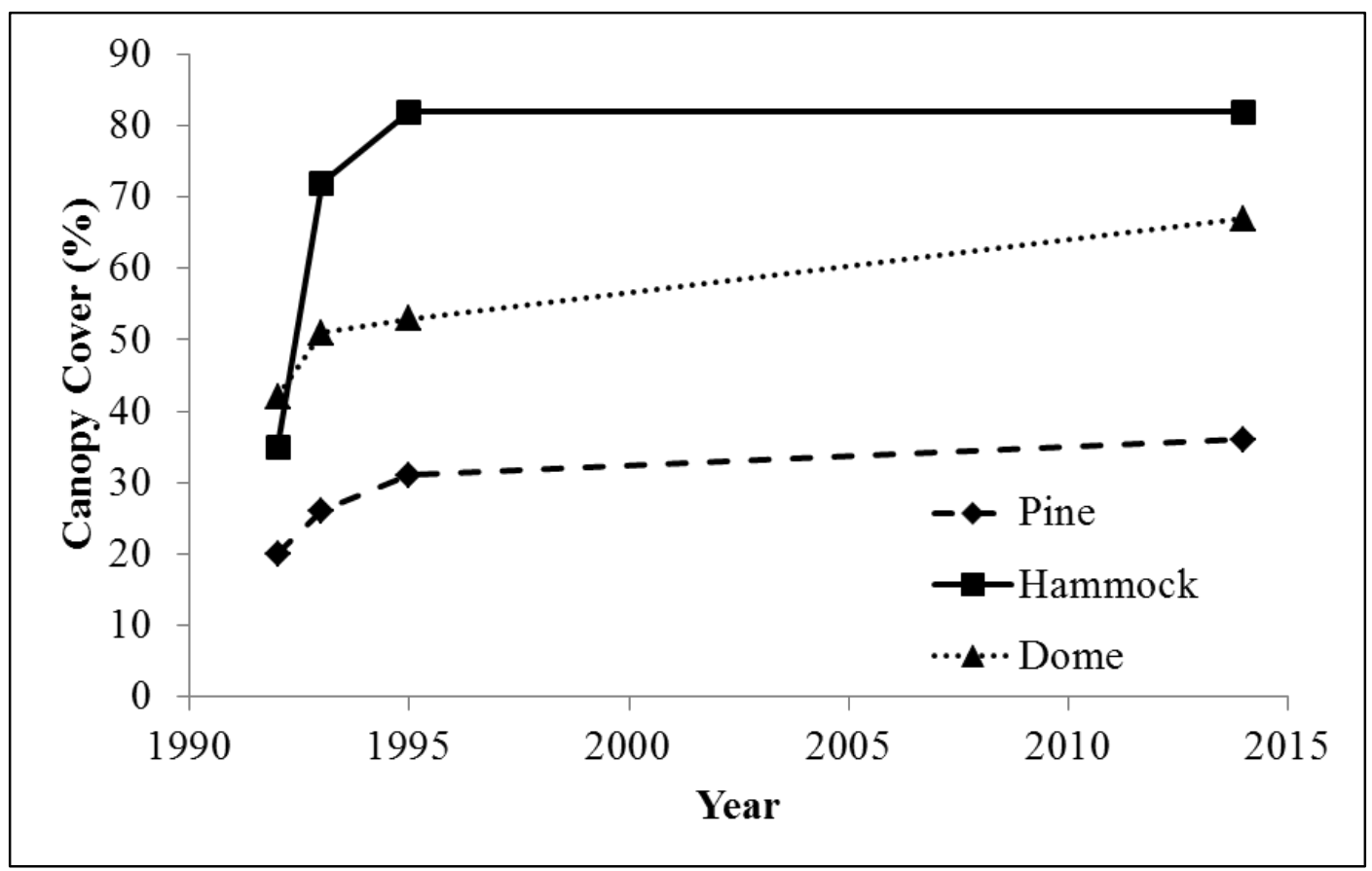

Figure II.4: Canopy closure of cypress dome (dotted), hardwood hammock (solid), and pineland (dashed) communities during the recovery after Hurricane Andrew. 


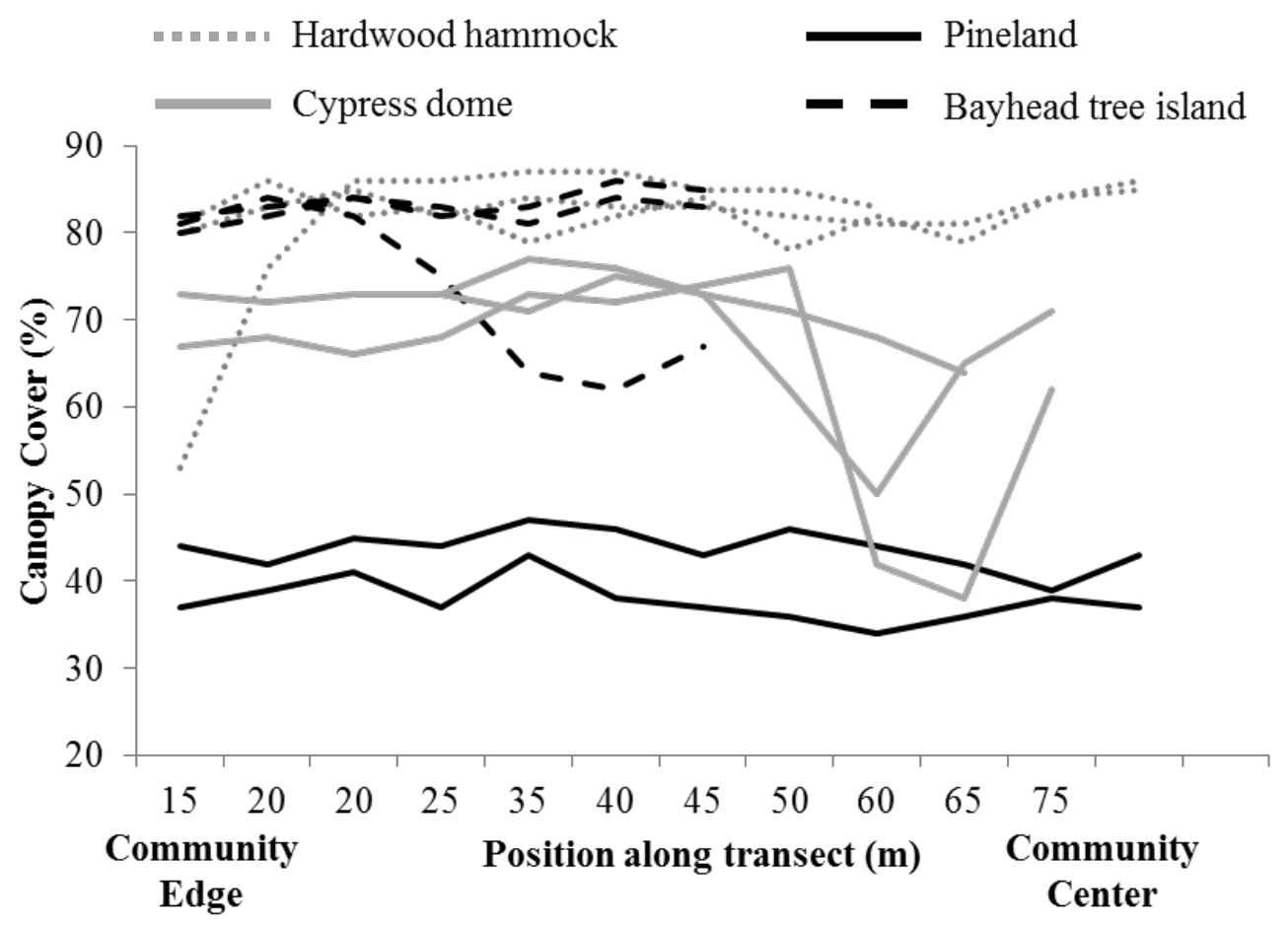

Figure II.5: Canopy cover associated with position along survey transects for hardwood hammocks (grey dotted), cypress dome (grey solid), pineland (black solid), and bayhead tree island (black dashed). 

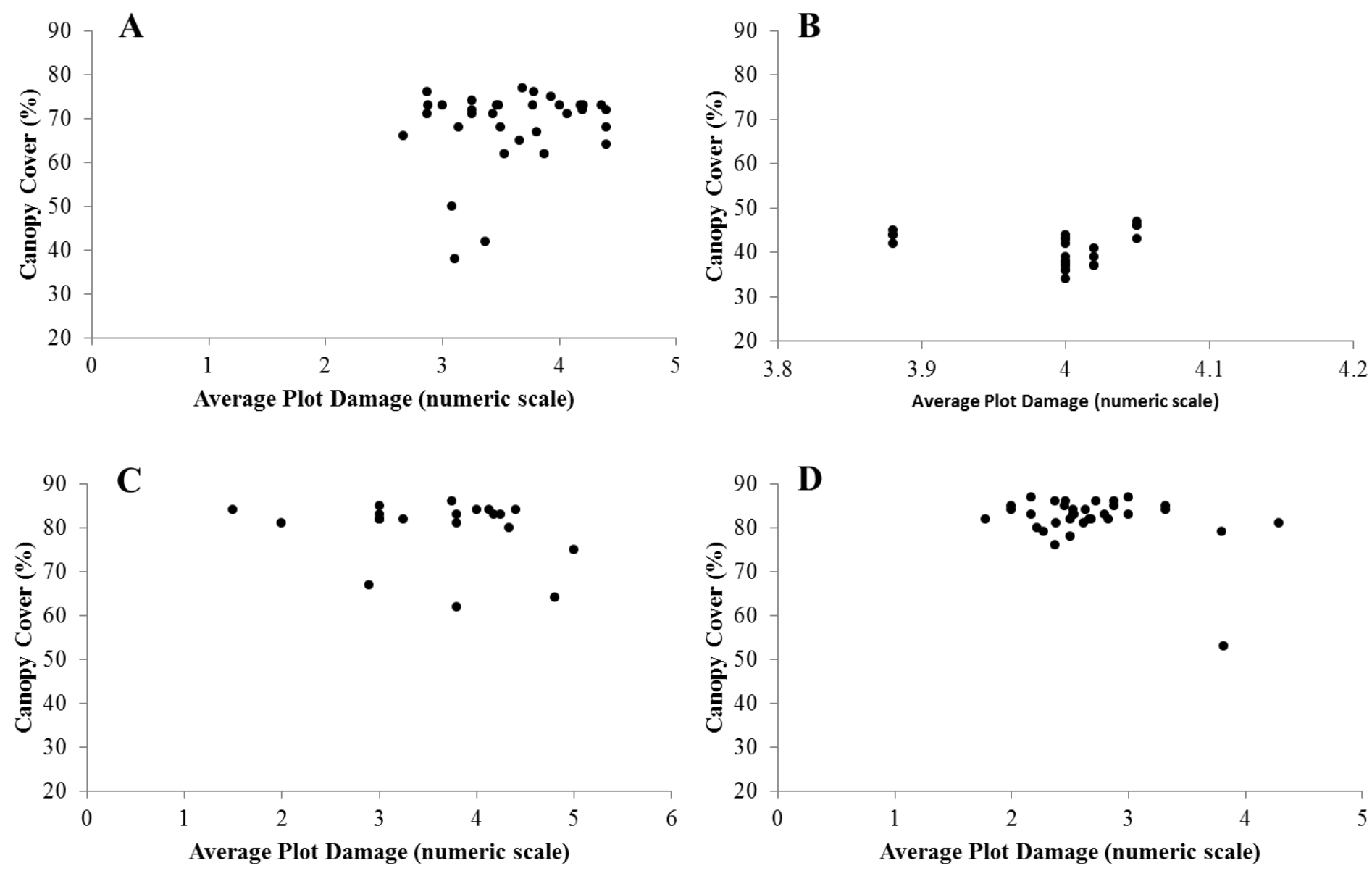

Figure II.6: Canopy cover in cypress dome (A), pineland (B), bayhead tree island (C), and hardwood hammock (D) community plots after 21 years (2014) of recovery post Hurricane Andrew, compared to initial (1993) average plot damage. 


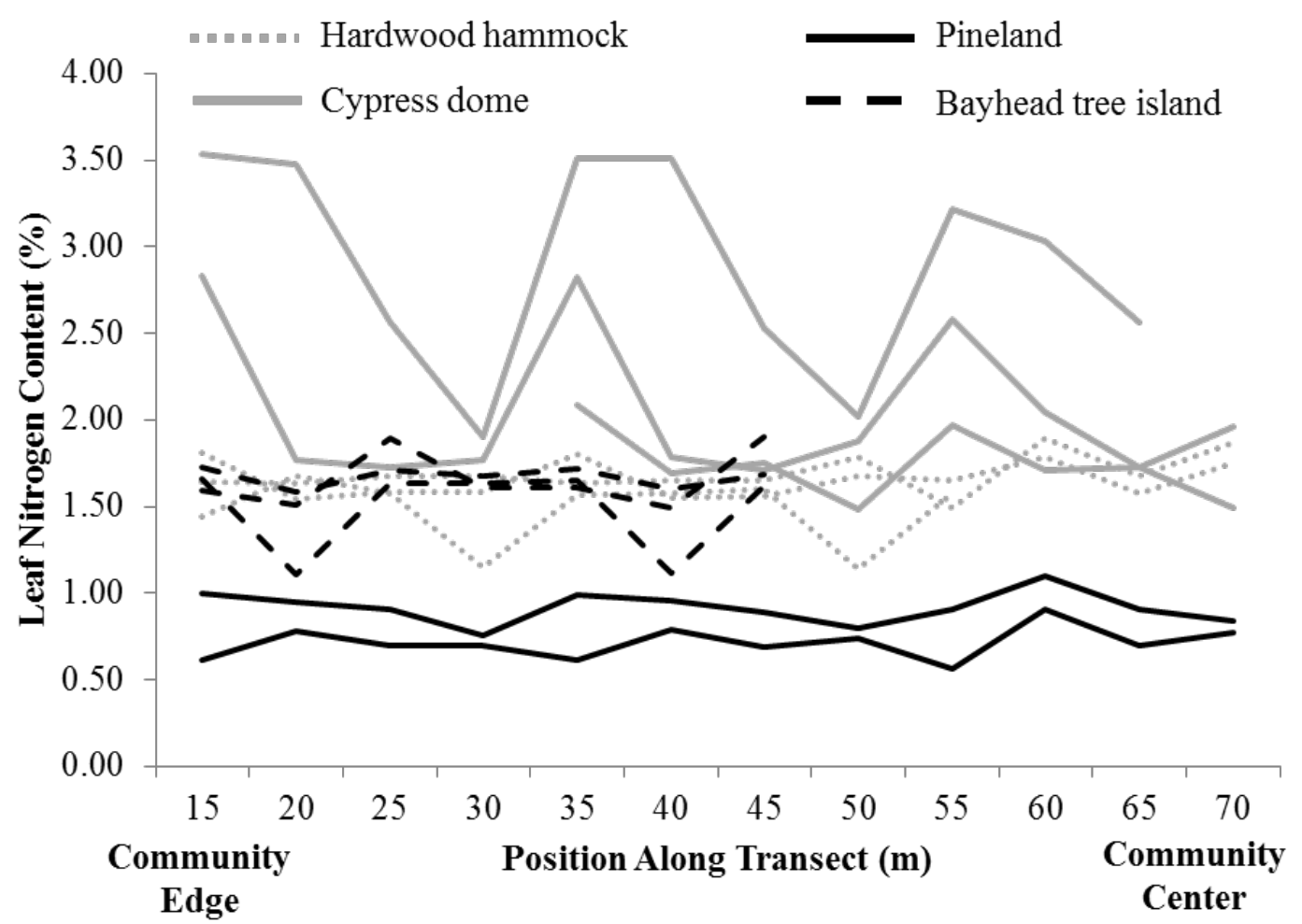

Figure II.7: Leaf nitrogen content with position along survey transects for hardwood hammocks (grey dotted), cypress dome (grey solid), pineland (black solid), and bayhead tree island (black dashed). 


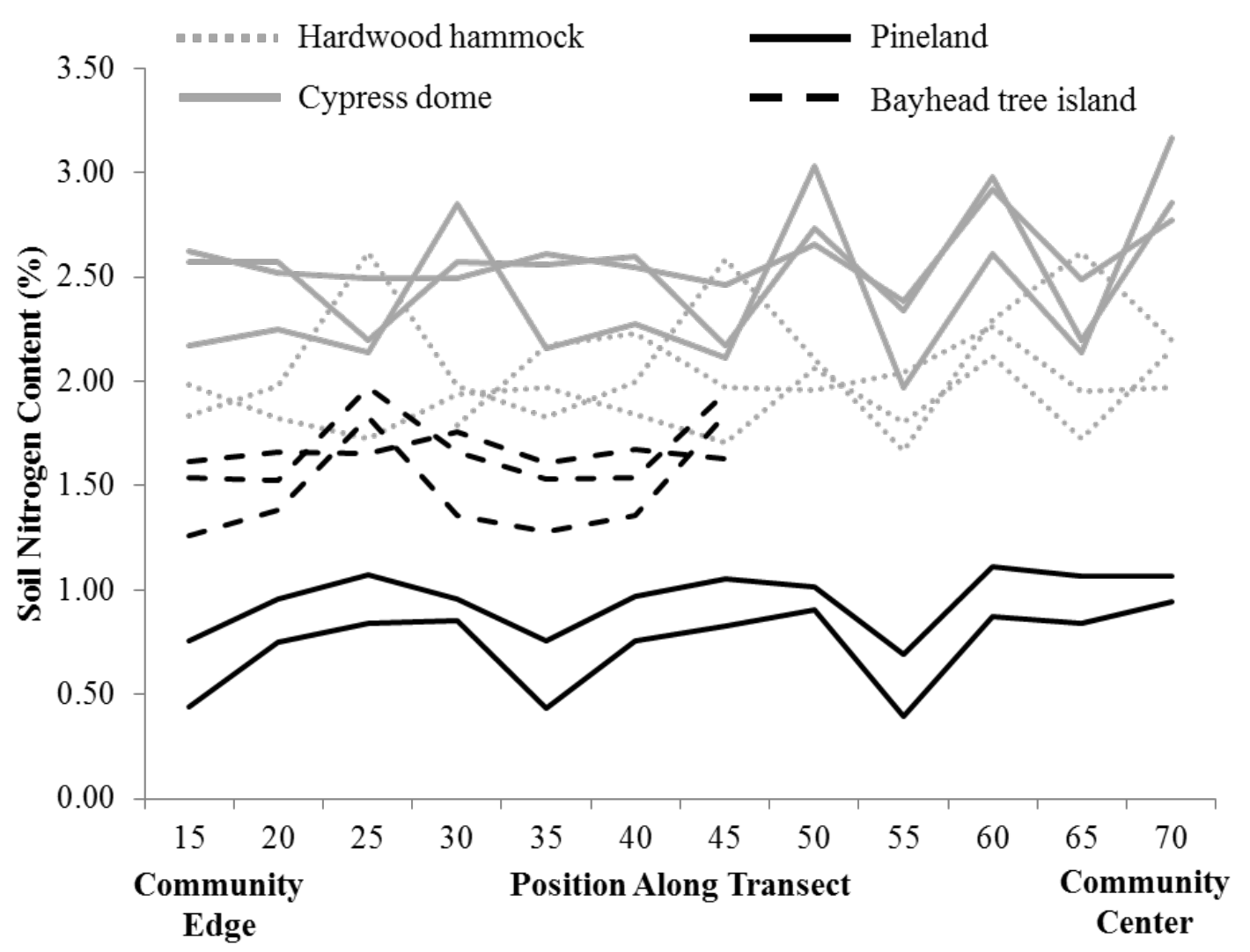

Figure II.8: Soil nitrogen content with position along survey transects for hardwood hammocks (grey dotted), cypress dome (grey solid), pineland (black solid), and bayhead tree island (black dashed). 

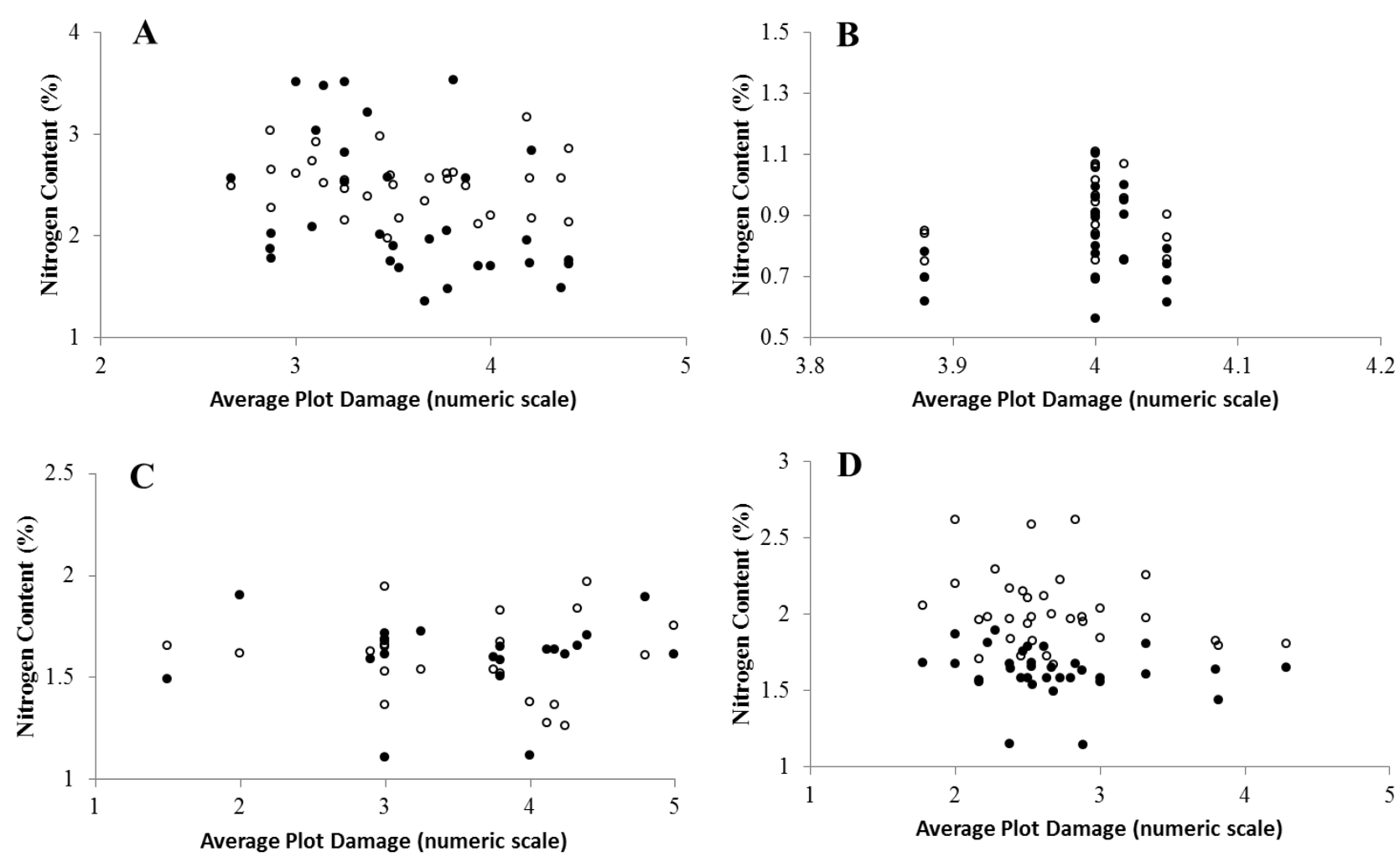

Figure II.9: Leaf (solid fill) and soil (open fill) nitrogen content in cypress dome (A), pineland (B), bayhead tree island (C), and hardwood hammock (D) community plots after 21 years (2014) of recovery post Hurricane Andrew compared to initial average plot damage (1993). 


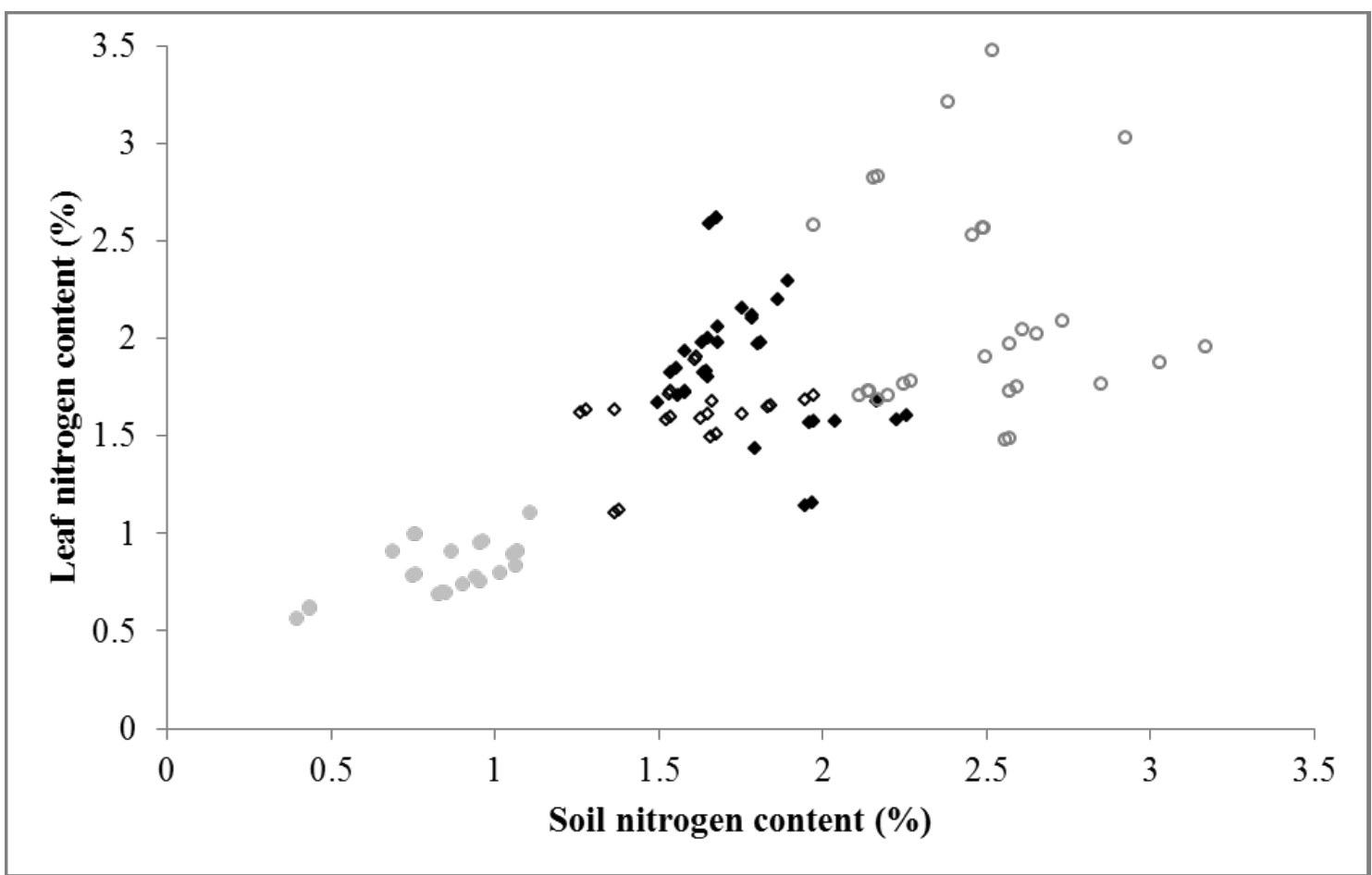

Figure II.10: Comparison of soil and leaf nutrient content in pineland (grey filled), cypress dome (grey open), hardwood hammock (black filled), and bayhead tree island (black open) community plots after 21 years (2014) of recovery post Hurricane Andrew. 
III: Species Diversity Shifts in Response to Hurricane Impact in Four Non-Tidal Forest Communities over Varying Temporal Scales in the Florida Everglades

\section{III.1: Abstract}

Hurricanes are periodic, large scale disturbance events in low latitude regions of the globe that can have lasting effects on forest communities. Climate change associated shifts in hurricane patterns of frequency and intensity have the potential to impact forest communities. Hurricane Andrew, a powerful category 5 hurricane, came ashore in southern Florida on August 24, 1992 and caused widespread devastation to the region, including plant communities located within Everglades National Park. The Hurricane Andrew Recovery Team (HART) project was created to document the storm damage and the subsequent recovery of vegetation communities in the region, including pineland, hardwood hammock, bayhead tree island, and cypress dome forest communities. Initial surveys were conducted in 1993 to assess pre-hurricane community makeup, structure, and damage. This initial survey was followed by subsequent yearly surveys through 1996, and an additional survey in 2012-13 to monitor short- and long-term recovery. The magnitude of species diversity varied across community types and the diversity changed across time scales. Short-term recovery showed little or no change in diversity from prehurricane values in all four communities. Over longer time scales there was a loss in diversity within hardwood hammocks (the most diverse community type) resulting from the loss of rare species. Loss and gain of species within each of the communities was often driven by the disturbance tolerance of individual species; however, the highest loss 
was in infrequent or rare species. Increasing damage extent was correlated with a loss in species diversity over the long-term time scale and across size classes. Trees in the smallest size classes were lost to mortality at higher frequency compared to larger individuals in all community types across both time short- and long-term time scales. The delayed effect of species loss in the most diverse communities in this study demonstrates the importance of long-term monitoring of hurricane impacted areas. Increases in hurricane intensity or frequency have the potential to lead to communities dominated by disturbance-tolerant species at the expense of rare species.

\section{III.3: Introduction}

The regular occurrence of hurricane-associated damage is an important factor in shaping the structure and composition of tropical and sub-tropical forest ecosystems (Lugo 2008), however, little is known about how forest communities recover from hurricanes over varying time scales. Climate change is expected to alter the periodicity and severity of hurricanes (Bender et al. 2010; Knutson et al. 2010) and shifts in patterns and strength may affect the time required for forests to recover from hurricane damage. Forest communities in the Everglades are adapted to hurricane disturbances (Gunderson 1994), but increased frequency and/or intensity of hurricanes or increases in the length of time to fully recover from storm damage may potentially lead to a diversity shift within communities. Understanding the shifts that occur within a community as it recovers is important to predicting the health and longevity of Everglades forest communities.

Widespread forest devastation is a common characteristic of hurricane impacts (Boose et al. 1994; Stanturf et al. 2007; Zimmerman et al. 1994). How individual plants 
and communities respond to this type of periodic impact, both in terms of damage susceptibility and regeneration, is key to the recovery of the system. Through time, hurricane impacts have collectively formed a distinct matrix of heterogeneous landscape effects in the Everglades and across Florida (Doyle 2009). Forests of varying ages are affected by damage in different ways, often showing higher mortality in a variety of size classes (Flynn et al. 2010).

Hurricane damage varies within an impacted community, often dependent on plant species, age, size, and neighboring trees. Tall mature trees may be severely damaged by strong winds and lightning, while small trees and understory vegetation can be sheltered from the damages of wind and lightning (Smith et al 1994; Platt et al. 2000; Platt et al. 2002; Gilliam et al. 2006; Zhang et al. 2008). In some cases understory plants are damaged at increased rates as a result of falling debris from canopy-level trees (Navarro-Martinez et al. 2012). Damaged trees adjacent to large undamaged trees may be unable to take advantage of changing environmental conditions and available resources because large neighbors quickly recover. Despite the heterogeneity of damage, overall mortality within a community has been shown to be low or delayed after hurricane impact (Baldwin et al. 2006; Marra et al. 2014; Piou et al 2006; Xi et al. 2008). While mortality is low in the canopy species, there can be a loss of rare species within the affected communities (Whigham et al. 1991; Vandecar et al. 2011) or the invasion of exotic species after the storms (Xi et al. 2008).

Many trees within the Everglades have suites of traits that allow them to persist after these disturbances, such as resistance to snapping off or quickly resprouting after 
damage (Gunderson 1994), and these traits effectively increase community resilience to hurricane impacts. Resilience is defined here as the return to a stable condition following a disturbance (Gunderson 2000). Despite the prevalence of hurricanes in the Everglades and a number of studies on the initial damage caused by Hurricane Andrew, few studies have investigated the long-term impacts of hurricanes on Everglade forest communities. Forest communities play key roles in the Everglades system as diversity hot spots and wildlife habitat (Gunderson 1994). Shifts in community composition can potentially impact the overall health and function of ecosystems (Fischer et al. 2013; Luke et al. 2014)

I investigated individual plant responses, community composition, and structural shifts associated with the 1992 landfall of Hurricane Andrew, a category 5 hurricane, in four Everglades non-tidal forest community types (pinelands, hardwood hammock, tree islands, and cypress domes) that differ greatly in terms of canopy species diversity, susceptibility to wind damage, and recovery patterns. I explored changes in community composition and the response of communities dominated by single species compared to that of more diverse communities. Specifically I addressed the following questions: 1) How does diversity and community structure change over short- and long-term recovery? 2) Are there patterns in the types of species that appear or disappear within a community during the recovery times? 3) How do increasing levels of damage within a community affect shifts in diversity? 


\section{III.3: Methods}

Study sites were established in 1993 within the Everglades National Park in southern Florida as part of the Hurricane Andrew Recovery Team (HART) project and were chosen because of their proximity to the path of Hurricane Andrew (Figure III.1). The study included four non-tidal forest communities; pinelands, hammocks, bayhead tree islands, and cypress domes. Three sites in each of the four community types (12 total sites) were established shortly after Hurricane Andrew's landfall in 1992. Within each of the sites a $100 \mathrm{~m}$ transect, or the length of the study community if less than $100 \mathrm{~m}$ in longest dimension, was established. Along each transect $5 \mathrm{~m}$ x $5 \mathrm{~m}$ survey plots for hardwood hammocks, bayhead tree islands and cypress domes, and 10m x 20m survey plots for pinelands were established on alternating sides at intervals of 10m (Figure III.2). Survey sites were later grouped for analysis to create $100 \mathrm{~m}^{2}$ plots in bayhead tree islands, hardwood hammocks, and cypress domes.

Initial surveys were conducted in 1993 and each individual tree was assessed for size (diameter at breast, dbh), species, and visual assessment of damage category associated with the storm (Table III.1). Subsequent resurveys were conducted in 1996 and 2012-2013 to assess community change in the short- and long-term recovery time periods. Plot-level damage extent was determined by using the percentage of individuals within a plot that had major damage (categories 1-3, Table III.1). Individuals were tagged at the initial survey and survival of tagged individuals, as well as new individuals, were assessed in subsequent surveys over short- and long-term recovery periods. Individuals were tracked at each survey to determine mortality and growth through size classes. Size 
classes were defined in $5 \mathrm{~cm}$ increments ranging from the smallest individuals $(0.1-5 \mathrm{~cm}$ dbh) up to the largest $(40+\mathrm{cm}$ dbh).

Community data from the initial survey were compared to the short- and longterm recovery periods using Mann-Whitney U tests to determine shifts in the diversity (species richness, evenness, Shannon-Wiener diversity index, and Simpson diversity index) and changes in average individual basal area. Effects of plot damage extent on species richness were assessed using linear regressions. An analysis outlining the loss and gain of individual species within plots of each community and the shifts between size classes across the recovery periods was also performed.

\section{III.4: Results}

Total number of individuals decreased dramatically in all communities over shortand long-term recovery time periods (Table III.2), except in bayhead tree islands. During the short-term recovery period, there was an increase of 28 individuals in the bayhead tree islands overall. However this increase disappeared after 20 years. The magnitude of individual loss varied by community type, with cypress domes losing the most individuals (154) and the other three community types having smaller declines (loss of 68 to 86 individuals). In all communities species with lower abundances were more likely to entirely disappear from plots. Individuals tagged in the initial survey decreased in abundance over both time scales, however the decreases in abundance were larger over the long-term time scale than species that were abundant. Tagged individuals were confirmed dead through verification using a coordinate mapping system in each plot which ensured that individuals were not lost due to tag droppage. 
The loss and gain of species within study plots across the long-term time scale varied between species, community type, and disturbance tolerance (Figure III.3). In bayhead tree islands, much of the loss was in disturbance intolerant species (e.g., Bumelia salicifolia and Quercus virginiana) and an increase in disturbance tolerant species (e.g., Metopium toxiferum) (Fralish and Franklin 2002; Sklar and van der Valk 2012). Species responses were mixed within hardwood hammock communities, but disturbance intolerant species did not increase in any plots. Changes in frequency of disturbance tolerant and intolerant species were mixed in both pineland and cypress dome communities.

Patterns and magnitude of the shifts in size class structure were community specific, however most showed a decrease in abundance of individuals in the smallest size classes (0.1-5cm dbh, Figure III.4). Cypress domes, pinelands, and hardwood hammocks all showed consistent decreases in the smallest size class. Bayhead tree islands showed the only increase in the smallest size class over the short-term recovery period, although this increase was lost over the long-term recovery period, resulting in a net loss of the smallest individuals.

Over the short-term recovery period, most individuals did not shift between size classes from their initial 1993 size class (Table III.3). The smallest size classes suffered the highest rates of mortality over the short-term, three year recovery period. The most frequent shifts from a smaller size class to a larger one occurred in cypress domes (53 individuals) and pinelands (85 individuals). For all community types shifts between size classes occurred from the smallest two classes $(0.1-5$ and $5.1-10 \mathrm{~cm}$ dbh) growing into the 
next larger size classes, while none of the largest individuals in the communities moved between size classes.

While the long-term recovery period showed a large number of shifts from smaller to larger size classes in all communities (Table III.4), the long-term recovery period also had high levels of mortality in individuals from the initial survey. Most of this mortality was confined to individuals that populated the smallest size classes. Community types with the highest number of species present at the initial sampling, bayhead tree islands and hardwood hammocks, had the highest levels of mortality over the long-term recovery period.

Changes in average individual basal area over the long and short recovery period varied by community type (Table III.5). Short-term (1993-96) recovery resulted in an increase in average individual basal area only in pineland communities compared to the initial survey $\left(+7.53 \mathrm{~cm}^{2}, \mathrm{p}<0.001\right)$, and this increase continued into the long-term recovery time period $\left(1996-2012,+4.86 \mathrm{~cm}^{2}, \mathrm{p}=0.002\right)$. Bayhead tree island and hardwood hammock average tree basal areas did not change over the short-term recovery, however both significantly increased over the long-term $\left(+7.85 \mathrm{~cm}^{2}\right.$ and $+5.33 \mathrm{~cm}^{2}$ respectively, both $\mathrm{p}<0.001)$.

As might be expected, changes in species diversity were higher over the longterm recovery (20 year) time period compared to short-term recovery (3 year, Table III.5). Diversity changes over the short-term recovery time period were mixed, however all shifts were small and none were statistically significant. Most community types had 
no significant changes, with only hardwood hammocks having significant declines in richness (-3.89, $\mathrm{p}=0.002$ and Shannon-Weiner diversity index $(-0.39, \mathrm{p}<0.001)$.

Increased plot level damage was negatively correlated with species richness in no communities over long-term recovery time scales, except bayhead tree islands (Figure III.5). Damage extent had the most impact on species richness within the bayhead tree island communities ( $\mathrm{p}=0.004)$. All of the communities, except hardwood hammocks,

showed some level of greater species richness as a result of lower damage levels over the long-term recovery period. Cypress domes correlations were not significant and were driven buy outliers.

\section{III.5: Discussion}

Species diversity was not altered by hurricane damage in most of the community types over the short-term (3 year) study period. The resistance to diversity change continued over the long-term (20 year) period for three of the community types, however there was a increased level of loss in species diversity over the long-term scale compared to the short-term recovery period. The most diverse community type (hardwood hammocks) showed the only long-term decline in species diversity. The decrease in diversity within the hardwood hammocks was the result of the loss of rare species within the community, making the loss of a single or a few individuals result in complete species loss. Less diverse communities, pineland and cypress dome, showed little or no change in diversity over both time scales, likely a result of redundancy of individuals of a single dominant species. All of the communities, except cypress domes, showed a significant net increase in average individual basal area over the course of the study as a result of 
individuals in the smallest size classes becoming less frequent over time. The loss of smallest size class occupants was driven primarily by high mortality.

The frequency loss of individuals of the smallest size classes is a result of two factors occurring over the long-term recovery period. Smaller size classes experienced higher levels of mortality and surviving individuals grew up into larger size classes during the 20 year period. Individuals refoliated and resprouted damaged branches in response to changing environmental conditions after hurricane disturbance. The individuals that populated the smallest size classes likely had lower levels of caloric reserves than large individuals, and these limited reserves were consumed in the process of resprouting and refoliation. These smaller individuals are shaded and competing with larger individuals for soil nutrients. The consumption of finite resources may contribute to decreased ability for future growth and to the higher levels of small individual mortality over the long-term recovery period.

The hurricane damage also caused new habitats to be formed that were available for colonization by recruits. Defoliation caused incoming photosynthetic radiation and moisture shifts within the canopy, and this was present across community types, although there was also novel new habitat formation that was community specific. New habitat formation was especially true in cypress domes where mature tree tip-ups caused soil mounds at the trunk base. These mounds are temporarily available for recruit colonization; however dissipate as a result of erosion.

Each community type had unique patterns of species that were lost or gained over the length of the study. The biggest shifts in species loss/gain were in the most diverse 
communities; the hardwood hammock and bayhead tree islands. In hammocks and tree islands there appeared to be a shift in the communities to an increasing frequency of disturbance tolerant species at the cost of disturbance intolerant species. Pineland and cypress domes are each dominated by a single species that are tolerant of the unique conditions (i.e., thin soil layer, frequent fire, and long hydroperiod) that these two communities exhibit, respectively. As a result, only peripheral species were lost in pineland and cypress domes, causing little shift in overall diversity. The loss of peripheral species in the pineland communities could also be a result of a National Park Service managed fire regime designed to maintain the system's natural ecology.

Increasing extents of damage in all of the four community types resulted in negative shifts in species richness over the length of the study. Only hardwood hammocks showed a consistent loss of species richness across all damage levels. It is worth noting that hammocks were the only habitats in which more than $50 \%$ of individuals were damaged in all plots. All of the other community types showed some increases of species richness at lower damage extents, except cypress domes, suggesting that minor damage may level the competitive landscape between individuals or allow for new species colonization possibly as a result of lowered competitive advantage. Shifts in competitive advantage is consistent with published results showing that storm damage of varying degrees can alter community regeneration trajectories and resulting dominant species makeup (Baldwin et al. 2001). Cypress domes were the community types that showed the least change in species richness with damage extent, likely because the long hydroperiods within the dome excluding new species colonization. 
The decreases in species richness and the shift toward disturbance tolerant species could have broad implications in the most diverse communities of the Everglades. These composition shifts may alter the use of hardwood hammocks and bayhead tree islands as wildlife habitat and food sources for migratory birds (Gunderson 1994). Increases in damage extent or intensity could result in increased loss of rare species. Over the course of this study, there was a loss of two species from some plots in hardwood hammocks and bayhead tree islands that are categorized as being vulnerable or in peril by the International Union for the Conservation of Nature (Myrsine floridiana, and Coccoloba diversifolia).

Our results were generally consistent with other studies investigating the recovery of forest communities from hurricane damage. Increasing levels of damage resulted in a loss of species diversity in sites that initially had high levels of diversity (Marra et al. 2014). The most significant shift in age/size classes within the smallest individuals was also found in other studies (Flynn et al. 2010). The short-term recovery surveys showed little change in diversity and structure, however the long-term recovery survey showed a pronounced shift. This is consistent with delayed mortality and other studies not resulting in diversity shift when studying shorter time scales (Xi et al. 2008; Flynn et al. 2010). Mortality levels were higher in the smallest individuals that have lower nutrient reserves and are more susceptible to being outcompeted by larger, more established individuals during the recovery period. The delay in mortality and impacts of the hurricane disturbance demonstrates that the effects of such events can have long lasting consequences that are not necessarily demonstrated in short-term recovery 
periods. Delayed mortality had no overall effect in the two communities with a single dominant species, cypress domes and pinelands.

In conclusion, shifts in community composition and structure associated with hurricane damage had the largest effects on the most diverse communities, however these shifts did not manifest in the short-term (3 year) recovery post-Hurricane Andrew. Our results emphasize that longer term monitoring needs to be conducted on sites where hurricane damage recovery is being investigated to more accurately document cases of delayed mortality. Delayed mortality after storm damage has the potential to cause rare species to become locally extinct. Predicted shifts in hurricane intensity and frequency emphasize the importance of understanding how varying levels of damage can impact forest communities and how long is required before the full impact becomes apparent.

\section{III.6: References}

Baldwin, A., M. Egnotovich, M. Ford, W. Platt. 2001. "Regeneration in fringe mangrove forests damaged by Hurricane Andrew.” Plant Ecology 157: 151-164.

Bender, M. A., T. R. Knutson, R. E. Tuleya, J. J. Sirutis, G. A Vecchi, S. T. Garner, I. M. Held. 2010. "Modeled impact of anthropogenic warming on the frequency of intense Atlantic hurricanes.” Science 327:454-458.

Boose, E. R., D. R. Foster, M. Fluet. 1994. "Hurricane impacts to tropical and temperate forest landscapes.” Ecological Monographs 64: 369-400.

Doyle, T. W., K. W. Krauss, C. J. Wells. 2009. "Landscape analysis and pattern of hurricane impact and circulation on mangrove forests of the Everglades." Wetlands 29: 44-53.

Fischer, A., P. Marshall, A. Camp. 2013. "Disturbances in deciduous temperate forest ecosystems of the northern hemisphere: their effects on both recent and future forest development.” Biodiversity Conservation 22: 1863-1893. 
Flynn, D. F. B., M. Uriarte, T. Crk, J. B. Pascarella, J. K. Zimmerman, T. M. Aide, M. A. C. Ortiz. 2010 "Hurricane disturbance alters secondary forest recovery in Puerto Rico." Biotropica 42:149-157.

Fralish, J. S. and S. B. Franklin. 2002. "Taxonomy and ecology of woody plants in North American Forests: excluding Mexico and subtropical Florida” John Wiley and Sons.

Gilliam, F. S., W. J. Platt, et al. 2006. "Natural disturbances and the physiognomy of pine savannas: A phenomenological model.” Applied Vegetation Science 9:83-96.

Gunderson, L. H. 1994. "Vegetation of the Everglades: Determinants of Community Composition.” Everglades:The Ecosystem and Its Restoration. S. M. Davis and J. C. Ogden eds. CRC Press.

Gunderson, L. H. 2000. “Ecological Resilience: In Theory and Application.” Annual Review of Ecology and Systematics 31: 425-439.

Knutson, T. R., J. L. McBride, J. Chan, K. Emanuel, G. Holland, C. Landsea, I. Held, J Kossin, A. K. Srivastava, M. Sugi. 2010. “Tropical cyclones and climate change.” Nature Geoscience 3:157-163.

Luke, D., K. McLaren, B. Wilson. 2014. “The effects of a hurricane on seedling dynamics and abiotic interactions in a tropical lower montane wet forest.” Journal of Tropical Biology 30: 55-66.

Lugo, A. E. 2008. "Visible and invisible effects of hurricanes on forest ecosystems: An international review.” Austral Ecology 33:368-398.

Marra, D. M., J. Q. Chambers, N. Higuchi, S. E. Trumbore, G. H. P. M. Ribeiro, J. dos Santos, R. I. Negrón-Juarez, B. Reu, C. Wirth. 2014 "Large-scale wind disturbances promote tree diversity in a Central Amazon Forest.” PLOS One. 9:e103711.

Navarro-Martinez, A., R. Duran-Garcia, et al. 2012 “The impact of Hurricane Dean on the structure and arboreal composition of a managed forest in Quintana Roo, Mexico. Madera Y Bosques.” 18:57-76.

Piou, C., I. C. Feller, U. Berger, F. Chi. 2006. “Zonation patterns of Belizean offshore mangrove forests 41 years after a catastrophic hurricane.” Biotropica. 38: 365-374.

Platt, W. J., R. F. Doren, T. V. Armentano. 2000 "Effects of Hurricane Andrew on stands of slash pine (Pinus elliottii var. densa) in the everglades region of south Florida (USA)." Plant Ecology 146:43-60. 
Platt, W. J., B. Beckage, R. F. Doren, H. H. Slater. 2002 "Interactions of large-scale disturbances: Prior fire regimes and hurricane mortality of savanna pines.” Ecology 83:1566-1572.

Sklar, F. H. and A. van der Valk. 2012 “Tree islands of the Everglades”. Springer Science and Business Media.

Smith, T.J., M. B. Robblee, H. R. Wanless, T. W. Doyle. 1994. “Mangroves, hurricanes, and lightning strikes. BioScience, 44(4): 256-262.

Stanturf, J. A., S. L. Goodrick, K. W. Outcalt. 2007 "Disturbance and coastal forests: A strategic approach to forest management in hurricane impact zones.” Forest Ecology and Management. 250:119-135.

Vandecar, K. L., D. Lawrence, D. Richards, L. Schneider, J. Rogan, B. Schmook, H. Wilbur. 2011. "High Mortality for Rare Species Following Hurricane Disturbance in the Southern Yucatan.” Biotropica. 43:676-684.

Whigham, D. F., I. Olmsted, E. C. Cano, M. E. Harmon. 1991. “The impact of Hurricane Gilbert on trees, litterfall, and woody debris in a in a dry tropical forest in the northeastern Yucatan Peninsula.” Biotropica. 23:434-441.

Xi, W., R. K. Peel, D. L. Urban. 2008 “Changes in forest structure, species diversity and spatial pattern following hurricane disturbance in a Piedmont North Carolina forest, USA.” Journal of Plant Ecology. 1:43-57.

Zhang, K. Q., M. Simard, M. Ross, V. H. Rivera-Monroy, P. Houle, P. Ruiz, R. R. Twilley, K. R. T. Whelan. 2008 “Airborne laser scanning quantification of disturbances from hurricanes and lightning strikes to mangrove forests in Everglades National Park, USA.” Sensors. 8: 2262-2292.

Zimmerman, J. K., E. M. Everham III, R. B. Waide, D. J. Lodge, C. M. Taylor, N. V. Brokaw. 1994. "Responses of tree species to hurricane wind in subtropical wet forest in Puerto Rico- Implications for tropical tree life histories.” Journal of Ecology. 82:911-922. 
Table III.1: Damage classifications for initial vegetation assessments with number and proportions of affected individuals.

\begin{tabular}{clll}
$\begin{array}{c}\text { Damage } \\
\begin{array}{c}\text { Assessment } \\
\text { Numeric } \\
\text { Category }\end{array}\end{array}$ & Damage Type & n & \% \\
\hline 0 & No damage & 117 & 7.8 \\
1 & Bent Branches & 78 & 5.2 \\
2 & Minor Branch Damage & 513 & 34.1 \\
3 & Major Branch Damage & 397 & 26.4 \\
4 & Trunk Snap Off & 361 & 24.0 \\
5 & Tip Up & 38 & 2.5 \\
\hline
\end{tabular}


Table III.2: Frequency changes in the total number of individuals and individuals tagged in the initial (1993) survey over short(1996) and long-term (2012-13) recovery time periods.

\begin{tabular}{|c|c|c|c|c|c|c|c|c|}
\hline & \multicolumn{3}{|c|}{ Total Individuals } & \multicolumn{5}{|c|}{ Tagged Individuals From Hurricane Forward } \\
\hline & 1993 & 1996 & $\begin{array}{l}2012- \\
2013\end{array}$ & 1993 & 1996 & $\begin{array}{r}\% \\
\text { Survival } \\
\end{array}$ & $\begin{array}{r}2012- \\
2013 \\
\end{array}$ & $\begin{array}{r}\% \\
\text { Survival } \\
\end{array}$ \\
\hline \multicolumn{9}{|c|}{ Bayhead Tree Island } \\
\hline Total & 238 & 262 & 167 & 238 & 234 & 98 & 24 & 10 \\
\hline Ardisia escallonioides & 0 & 1 & 0 & 0 & 0 & - & 0 & - \\
\hline Bursera simaruba & 15 & 21 & 18 & 15 & 15 & 100 & 4 & 27 \\
\hline Bumelia salicifolia & 23 & 26 & 19 & 23 & 23 & 100 & 8 & 35 \\
\hline Chrysobalanus icaco & 2 & 2 & 0 & 2 & 2 & 100 & 0 & 0 \\
\hline Cephalanthus occidentalis & 1 & 1 & 0 & 1 & 1 & 100 & 0 & 0 \\
\hline Eugenia axillaris & 10 & 10 & 7 & 10 & 10 & 100 & 1 & 10 \\
\hline Exothea paniculata & 2 & 0 & 0 & 2 & 0 & 0 & 0 & 0 \\
\hline Ficus spp & 13 & 13 & 9 & 13 & 13 & 100 & 2 & 15 \\
\hline Ilex cassine & 11 & 11 & 13 & 11 & 11 & 100 & 0 & 0 \\
\hline Lysiloma bahamensis & 24 & 23 & 17 & 24 & 23 & 96 & 5 & 21 \\
\hline Myrica cerifera & 5 & 7 & 0 & 5 & 5 & 100 & 0 & 0 \\
\hline Myrsine floridana & 4 & 4 & 0 & 4 & 4 & 100 & 0 & 0 \\
\hline Metopium toxiferum & 11 & 13 & 41 & 11 & 11 & 100 & 4 & 36 \\
\hline Quercus virginiana & 35 & 42 & 20 & 35 & 35 & 100 & 0 & 0 \\
\hline Rhus copallina & 1 & 0 & 0 & 1 & 0 & 0 & 0 & 0 \\
\hline Schoepfia chrysophylloides & 1 & 1 & 0 & 1 & 1 & 100 & 0 & 0 \\
\hline Trema micrantha & 75 & 82 & 23 & 75 & 75 & 100 & 0 & 0 \\
\hline Unknown & 5 & 5 & 0 & 5 & 5 & 100 & 0 & 0 \\
\hline
\end{tabular}


Table III.2 continued....

\begin{tabular}{|c|c|c|c|c|c|c|c|c|}
\hline & \multicolumn{3}{|c|}{ Total Individuals } & \multicolumn{5}{|c|}{ Tagged Individuals From Hurricane Forward } \\
\hline & 1993 & 1996 & $\begin{array}{l}2012- \\
2013\end{array}$ & 1993 & 1996 & $\begin{array}{r}\% \\
\text { Survival }\end{array}$ & $\begin{array}{r}2012- \\
2013\end{array}$ & $\begin{array}{r}\% \\
\text { Survival }\end{array}$ \\
\hline \multicolumn{9}{|c|}{ Pineland } \\
\hline Total & 201 & 170 & 126 & 201 & 147 & 73 & 19 & 9 \\
\hline Bumelia celastrina & 2 & 2 & 0 & 2 & 2 & 100 & 0 & 0 \\
\hline Bumelia salicifolia & 10 & 9 & 2 & 10 & 9 & 90 & 0 & 0 \\
\hline Forestiera pinetorum & 1 & 1 & 0 & 1 & 1 & 100 & 0 & 0 \\
\hline Ilex cassine & 6 & 6 & 1 & 6 & 6 & 100 & 0 & 0 \\
\hline Lysiloma bahamensis & 1 & 1 & 0 & 1 & 1 & 100 & 0 & 0 \\
\hline Myrica cerifera & 13 & 10 & 11 & 13 & 10 & 77 & 0 & 0 \\
\hline Myrsine floridana & 6 & 4 & 0 & 6 & 4 & 67 & 0 & 0 \\
\hline Metopium toxiferum & 3 & 3 & 1 & 3 & 3 & 100 & 0 & 0 \\
\hline Persea borbonia & 8 & 7 & 2 & 8 & 7 & 88 & 0 & 0 \\
\hline Pinus elliottii & 151 & 127 & 109 & 151 & 104 & 69 & 19 & 13 \\
\hline \multicolumn{9}{|c|}{ Cypress Dome } \\
\hline Total & 845 & 804 & 691 & 845 & 795 & 94 & 675 & 80 \\
\hline Annona glabra & 2 & 2 & 2 & 2 & 2 & 100 & 2 & 100 \\
\hline Ficus spp & 6 & 5 & 3 & 6 & 5 & 83 & 3 & 50 \\
\hline Myrica cerifera & 6 & 6 & 0 & 6 & 6 & 100 & 0 & 0 \\
\hline Salix caroliniana & 5 & 5 & 3 & 5 & 5 & 100 & 3 & 60 \\
\hline Taxodium distichum & 826 & 786 & 683 & 826 & 777 & 94 & 667 & 81 \\
\hline
\end{tabular}


Table III.2 continued....

\begin{tabular}{|c|c|c|c|c|c|c|c|c|}
\hline & \multicolumn{3}{|c|}{ Total Individuals } & \multicolumn{5}{|c|}{ Tagged Individuals From Hurricane Forward } \\
\hline & 1993 & 1996 & $\begin{array}{l}2012- \\
2013\end{array}$ & 1993 & 1996 & $\begin{array}{r}\% \\
\text { Survival }\end{array}$ & $\begin{array}{r}2012- \\
2013\end{array}$ & $\begin{array}{r}\% \\
\text { Survival }\end{array}$ \\
\hline \multicolumn{9}{|c|}{ Hardwood Hammock } \\
\hline Total & 466 & 452 & 380 & 466 & 425 & 91 & 212 & 45 \\
\hline Ardisia escalloniodes & 21 & 21 & 8 & 21 & 19 & 90 & 6 & 29 \\
\hline Baccharis halimifolia & 1 & 1 & 0 & 1 & 1 & 100 & 0 & 0 \\
\hline Bursera simaruba & 27 & 24 & 25 & 27 & 24 & 89 & 17 & 63 \\
\hline Bumelia salicifolia & 51 & 50 & 50 & 51 & 49 & 96 & 32 & 63 \\
\hline Eugenia axillaris & 64 & 63 & 89 & 64 & 61 & 95 & 42 & 66 \\
\hline Erythrina herbacea & 2 & 1 & 1 & 2 & 1 & 50 & 1 & 50 \\
\hline Exothea paniculata & 11 & 11 & 5 & 11 & 11 & 100 & 5 & 45 \\
\hline Ficus spp & 12 & 11 & 7 & 12 & 11 & 92 & 6 & 50 \\
\hline Guettarda scabra & 6 & 6 & 3 & 6 & 6 & 100 & 1 & 17 \\
\hline Ilex cassine & 13 & 9 & 15 & 13 & 9 & 69 & 9 & 69 \\
\hline Lysiloma bahamensis & 47 & 47 & 41 & 47 & 44 & 94 & 19 & 40 \\
\hline Myrica cerifera & 1 & 1 & 0 & 1 & 1 & 100 & 0 & 0 \\
\hline Myrsine floridana & 14 & 13 & 0 & 14 & 13 & 93 & 0 & 0 \\
\hline Myricanthes fragrans & 16 & 15 & 6 & 16 & 13 & 81 & 5 & 31 \\
\hline Metopium toxiferum & 13 & 13 & 5 & 13 & 10 & 77 & 3 & 23 \\
\hline Nectandra coriacea & 49 & 47 & 24 & 49 & 44 & 90 & 10 & 20 \\
\hline Persea borbonia & 4 & 4 & 6 & 4 & 4 & 100 & 3 & 75 \\
\hline Pinus elliottii & 1 & 1 & 0 & 1 & 1 & 100 & 0 & 0 \\
\hline Prunus myrtifolia & 6 & 4 & 25 & 6 & 4 & 67 & 4 & 67 \\
\hline Quercus virginiana & 24 & 28 & 13 & 24 & 24 & 100 & 13 & 54 \\
\hline Schoepfia chrysophylloides & 4 & 4 & 0 & 4 & 4 & 100 & 0 & 0 \\
\hline
\end{tabular}


Table III. 2 continued....

\begin{tabular}{|c|c|c|c|c|c|c|c|c|}
\hline & \multicolumn{3}{|c|}{ Total Individuals } & \multicolumn{5}{|c|}{ Tagged Individuals From Hurricane Forward } \\
\hline & 1993 & 1996 & $\begin{array}{l}2012- \\
2013\end{array}$ & 1993 & 1996 & $\begin{array}{r}\% \\
\text { Survival } \\
\end{array}$ & $\begin{array}{r}2012- \\
2013\end{array}$ & $\begin{array}{r}\% \\
\text { Survival }\end{array}$ \\
\hline Simarouba glauca & 6 & 6 & 6 & 6 & 6 & 100 & 5 & 83 \\
\hline Tetrazygia bicolor & 3 & 3 & 6 & 3 & 3 & 100 & 1 & 33 \\
\hline Trema micrantha & 1 & 0 & 2 & 1 & 0 & 0 & 0 & 0 \\
\hline Unknown & 19 & 23 & 4 & 19 & 17 & 89 & 4 & 21 \\
\hline Vitis spp & 10 & 11 & 1 & 10 & 10 & 100 & 1 & 10 \\
\hline
\end{tabular}


Table III.3: Growth and mortality of individuals present at the initial survey (1993) into size class after the short-term recovery period (1996). No individuals decreased in size class between 1993 and 1996.

\begin{tabular}{|c|c|c|c|c|c|c|c|c|c|c|}
\hline \multirow[t]{4}{*}{1993} & \multicolumn{10}{|c|}{1996 (Short Term) } \\
\hline & & $0.1-$ & $5.1-$ & $10.1-$ & 15.1- & $20.1-$ & $25.1-$ & $30.1-$ & $35.1-$ & \\
\hline & Died & 5 & 10 & 15 & 20 & 25 & 30 & 35 & 40 & $40+$ \\
\hline & \multicolumn{10}{|c|}{ Bayhead Tree Island } \\
\hline Recruitment & & 29 & 1 & 0 & 0 & 0 & 0 & 0 & 0 & 0 \\
\hline $0.1-5$ & 4 & 131 & 5 & 0 & 0 & 0 & 0 & 0 & 0 & 0 \\
\hline $5.1-10$ & 1 & & 64 & 1 & 1 & 0 & 0 & 0 & 0 & 0 \\
\hline 10.1-15 & 1 & & & 9 & 2 & 0 & 0 & 0 & 0 & 0 \\
\hline $15.1-20$ & 0 & & & & 13 & 0 & 0 & 0 & 0 & 0 \\
\hline $20.1-25$ & 0 & & & & & 3 & 0 & 0 & 0 & 0 \\
\hline $25.1-30$ & 0 & & & & & & 2 & 0 & 0 & 0 \\
\hline $30.1-35$ & 0 & & & & & & & 1 & 0 & 0 \\
\hline $35.1-40$ & 0 & & & & & & & & 0 & 0 \\
\hline $40.1+$ & 0 & & & & & & & & & 0 \\
\hline \multicolumn{11}{|c|}{ Pineland } \\
\hline Recruitment & & 26 & 1 & 0 & 0 & 0 & 0 & 0 & 0 & 0 \\
\hline $0.1-5$ & 27 & 57 & 18 & 9 & 0 & 0 & 0 & 0 & 0 & 0 \\
\hline $5.1-10$ & 27 & & 0 & 51 & 5 & 2 & 0 & 0 & 0 & 0 \\
\hline $10.1-15$ & 4 & & & 0 & 1 & 0 & 0 & 0 & 0 & 0 \\
\hline $15.1-20$ & 0 & & & & 0 & 0 & 0 & 0 & 0 & 0 \\
\hline $20.1-25$ & 0 & & & & & 0 & 0 & 0 & 0 & 0 \\
\hline $25.1-30$ & 0 & & & & & & 0 & 0 & 0 & 0 \\
\hline $30.1-35$ & 0 & & & & & & & 0 & 0 & 0 \\
\hline $35.1-40$ & 0 & & & & & & & & 0 & 0 \\
\hline $40.1+$ & 0 & & & & & & & & & 0 \\
\hline
\end{tabular}


Table III.3 continued...

\begin{tabular}{|c|c|c|c|c|c|c|c|c|c|c|}
\hline \multirow[t]{4}{*}{1993} & \multicolumn{10}{|c|}{1996 (Short Term) } \\
\hline & & $0.1-$ & $5.1-$ & 10.1- & 15.1- & 20.1- & 25.1- & $30.1-$ & $35.1-$ & \\
\hline & Died & 5 & 10 & 15 & 20 & 25 & 30 & 35 & 40 & $40+$ \\
\hline & \multicolumn{10}{|c|}{ Cypress Dome } \\
\hline Recruitment & & 24 & 0 & 0 & 0 & 0 & 0 & 0 & 0 & 0 \\
\hline $0.1-5$ & 17 & 401 & 30 & 0 & 0 & 0 & 0 & 0 & 0 & 0 \\
\hline $5.1-10$ & 13 & & 227 & 16 & 0 & 0 & 0 & 0 & 0 & 0 \\
\hline $10.1-15$ & 18 & & & 68 & 6 & 0 & 0 & 0 & 0 & 0 \\
\hline $15.1-20$ & 13 & & & & 15 & 1 & 0 & 0 & 0 & 0 \\
\hline $20.1-25$ & 2 & & & & & 7 & 0 & 0 & 0 & 0 \\
\hline 25.1-30 & 2 & & & & & & 4 & 0 & 0 & 0 \\
\hline $30.1-35$ & 0 & & & & & & & 1 & 0 & 0 \\
\hline $35.1-40$ & 0 & & & & & & & & 3 & 0 \\
\hline $40.1+$ & 0 & & & & & & & & & 1 \\
\hline \multicolumn{11}{|c|}{ Hardwood Hammock } \\
\hline Recruitment & & 28 & 7 & 0 & 0 & 0 & 0 & 0 & 0 & 0 \\
\hline $0.1-5$ & 45 & 353 & 0 & 0 & 0 & 0 & 0 & 0 & 0 & 0 \\
\hline $5.1-10$ & 4 & & 54 & 0 & 0 & 0 & 0 & 0 & 0 & 0 \\
\hline 10.1-15 & 0 & & & 7 & 0 & 0 & 0 & 0 & 0 & 0 \\
\hline $15.1-20$ & 0 & & & & 1 & 0 & 0 & 0 & 0 & 0 \\
\hline $20.1-25$ & 0 & & & & & 1 & 0 & 0 & 0 & 0 \\
\hline $25.1-30$ & 0 & & & & & & 1 & 0 & 0 & 0 \\
\hline 30.1-35 & 0 & & & & & & & 0 & 0 & 0 \\
\hline $35.1-40$ & 0 & & & & & & & & 0 & 0 \\
\hline $40.1+$ & 0 & & & & & & & & & 0 \\
\hline
\end{tabular}


Table III.4: Growth and mortality of individuals present at the initial survey (1993) into size class after the long-term recovery period (2012-13). No individuals decreased in size class between 1993 and 2012-13.

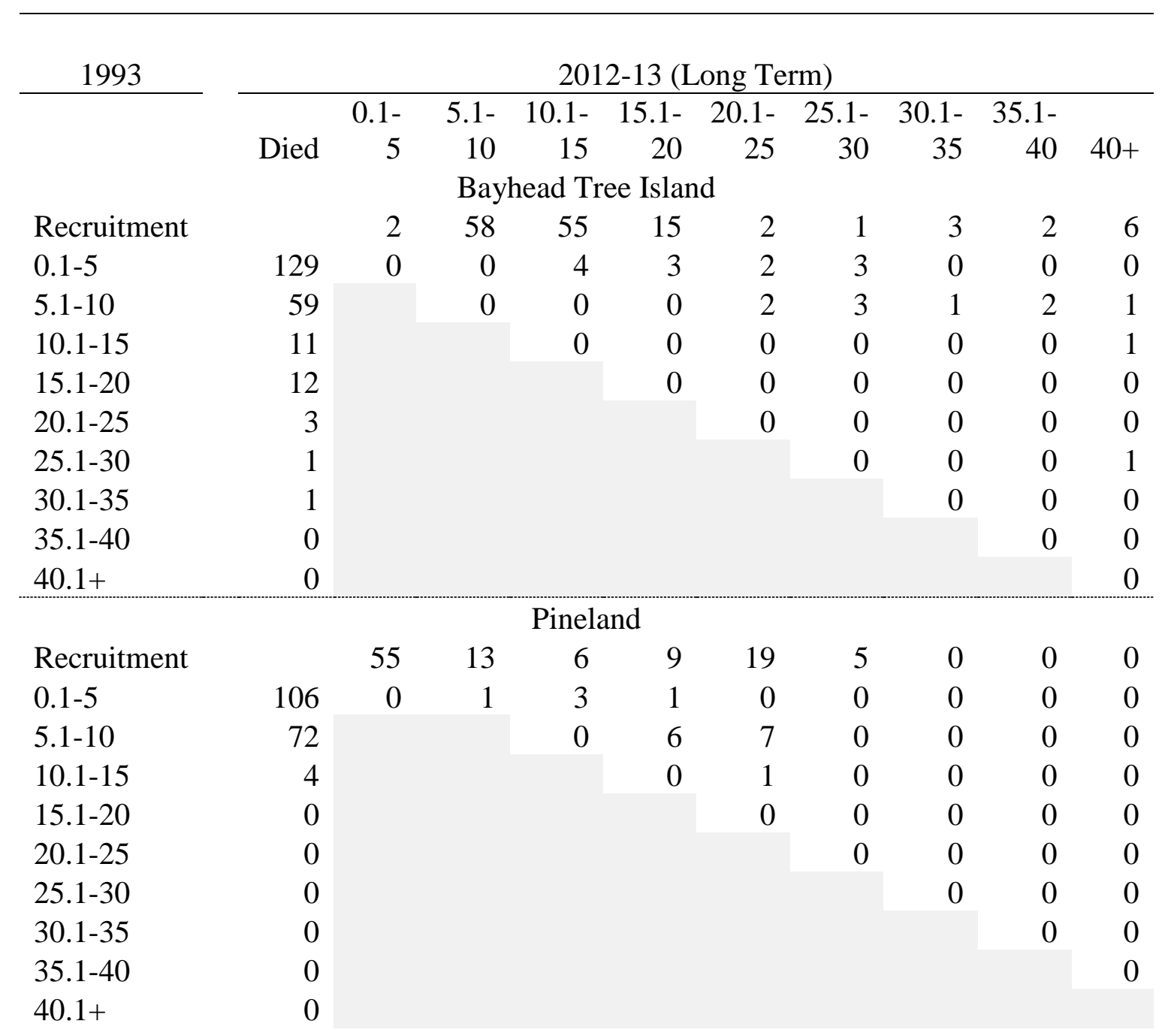




\section{Table III.4}

continued...

\begin{tabular}{|c|c|c|c|c|c|c|c|c|c|c|}
\hline \multirow[t]{2}{*}{1993} & \multicolumn{10}{|c|}{ 2012-13 (Long Term) } \\
\hline & Dind & $0.1-$ & 5.1- & $\begin{array}{r}10.1- \\
15\end{array}$ & 15.1- & 20.1- & 25.1- & $\begin{array}{r}30.1- \\
25\end{array}$ & 35.1- & $10+$ \\
\hline \multicolumn{11}{|c|}{ Cypress Dome } \\
\hline Recruitment & & 22 & 4 & 2 & 0 & 0 & 0 & 0 & 0 & 0 \\
\hline $0.1-5$ & 81 & 245 & 117 & 3 & 2 & 0 & 0 & 0 & 0 & 0 \\
\hline $5.1-10$ & 49 & & 144 & 61 & 3 & 1 & 0 & 0 & 0 & 0 \\
\hline $10.1-15$ & 33 & & & 30 & 28 & 0 & 0 & 0 & 0 & 0 \\
\hline $15.1-20$ & 15 & & & & 8 & 7 & 0 & 0 & 0 & 0 \\
\hline $20.1-25$ & 2 & & & & & 5 & 2 & 0 & 0 & 0 \\
\hline $25.1-30$ & 2 & & & & & & 4 & 0 & 0 & 0 \\
\hline $30.1-35$ & 0 & & & & & & & 0 & 1 & 0 \\
\hline $35.1-40$ & 0 & & & & & & & & 1 & 0 \\
\hline $40.1+$ & 0 & & & & & & & & & 1 \\
\hline \multicolumn{11}{|c|}{ Hardwood Hammock } \\
\hline Recruitment & & 145 & 23 & 0 & 1 & 0 & 0 & 0 & 0 & 0 \\
\hline $0.1-5$ & 223 & 79 & 64 & 28 & 4 & 0 & 0 & 0 & 0 & 0 \\
\hline $5.1-10$ & 28 & & 1 & 6 & 12 & 8 & 2 & 0 & 0 & 0 \\
\hline $10.1-15$ & 4 & & & 0 & 0 & 0 & 1 & 1 & 0 & 1 \\
\hline $15.1-20$ & 0 & & & & 0 & 0 & 0 & 0 & 1 & 1 \\
\hline $20.1-25$ & 0 & & & & & 0 & 1 & 0 & 0 & 0 \\
\hline $25.1-30$ & 0 & & & & & & 0 & 0 & 0 & 1 \\
\hline $30.1-35$ & 0 & & & & & & & 0 & 0 & 0 \\
\hline $35.1-40$ & 0 & & & & & & & & 0 & 0 \\
\hline $40.1+$ & 0 & & & & & & & & & 0 \\
\hline
\end{tabular}


Table III.5: Diversity shifts within four forest community plots over short- (3 year) and long-term (20 year) recovery from Hurricane Andrew. Statistical significance as a result of Mann-Whitney U tests comparing short-(1996) and long-term (2012-13) recovery compared with pre-hurricane conditions (1993) denoted by *.

\begin{tabular}{|c|c|c|c|c|}
\hline \multirow[b]{2}{*}{ Community } & \multirow[b]{2}{*}{$\mathbf{n}$} & \multirow[b]{2}{*}{ PreHurricane } & \multicolumn{2}{|c|}{ Recovery } \\
\hline & & & $\begin{array}{l}\text { Short- } \\
\text { Term }\end{array}$ & $\begin{array}{l}\text { Long- } \\
\text { Term }\end{array}$ \\
\hline \multicolumn{5}{|c|}{ Species Richness } \\
\hline Bayhead Tree Island & 6 & 4.78 & +0.16 & -0.81 \\
\hline Pineland & 9 & 3.33 & -0.22 & -1.58 \\
\hline Cypress Dome & 9 & 1.43 & 0 & -0.03 \\
\hline Hardwood & & & & \\
\hline Hammock & 9 & 14.44 & -0.22 & $-3.89 *$ \\
\hline \multicolumn{5}{|c|}{ Species Evenness } \\
\hline Bayhead Tree Island & 6 & 0.88 & 0 & +0.03 \\
\hline Pineland & 9 & 0.60 & 0.05 & +0.16 \\
\hline Cypress Dome & 9 & 0.93 & 0 & -0.02 \\
\hline Hardwood & & & & \\
\hline Hammock & 9 & 0.88 & 0 & -0.04 \\
\hline \multicolumn{5}{|c|}{ Simpson Diversity } \\
\hline Bayhead Tree Island & 6 & 0.93 & 0 & -0.09 \\
\hline Pineland & 9 & 0.56 & +0.01 & -0.08 \\
\hline Cypress Dome & 9 & 0.17 & 0 & +0.03 \\
\hline Hardwood & & & & \\
\hline Hammock & 9 & 0.99 & 0 & -0.01 \\
\hline \multicolumn{5}{|c|}{ Shannon Diversity } \\
\hline Bayhead Tree Island & 6 & 1.35 & +0.03 & -0.09 \\
\hline Pineland & 9 & 0.54 & 0 & -0.23 \\
\hline Cypress Dome & 9 & 0.09 & 0 & 0 \\
\hline Hardwood & & & & \\
\hline Hammock & 9 & 2.35 & -0.02 & $-0.39 *$ \\
\hline \multicolumn{5}{|c|}{ Average Individual Basal Area } \\
\hline Bayhead Tree Island & 6 & 4.67 & -0.16 & $+7.85 *$ \\
\hline Pineland & 9 & 2.26 & $+7.53 *$ & $+4.86 *$ \\
\hline $\begin{array}{l}\text { Cypress Dome } \\
\text { Hardwood }\end{array}$ & 9 & 6.71 & +0.21 & +1.16 \\
\hline Hammock & 9 & 1.18 & +0.07 & $+5.33 *$ \\
\hline
\end{tabular}




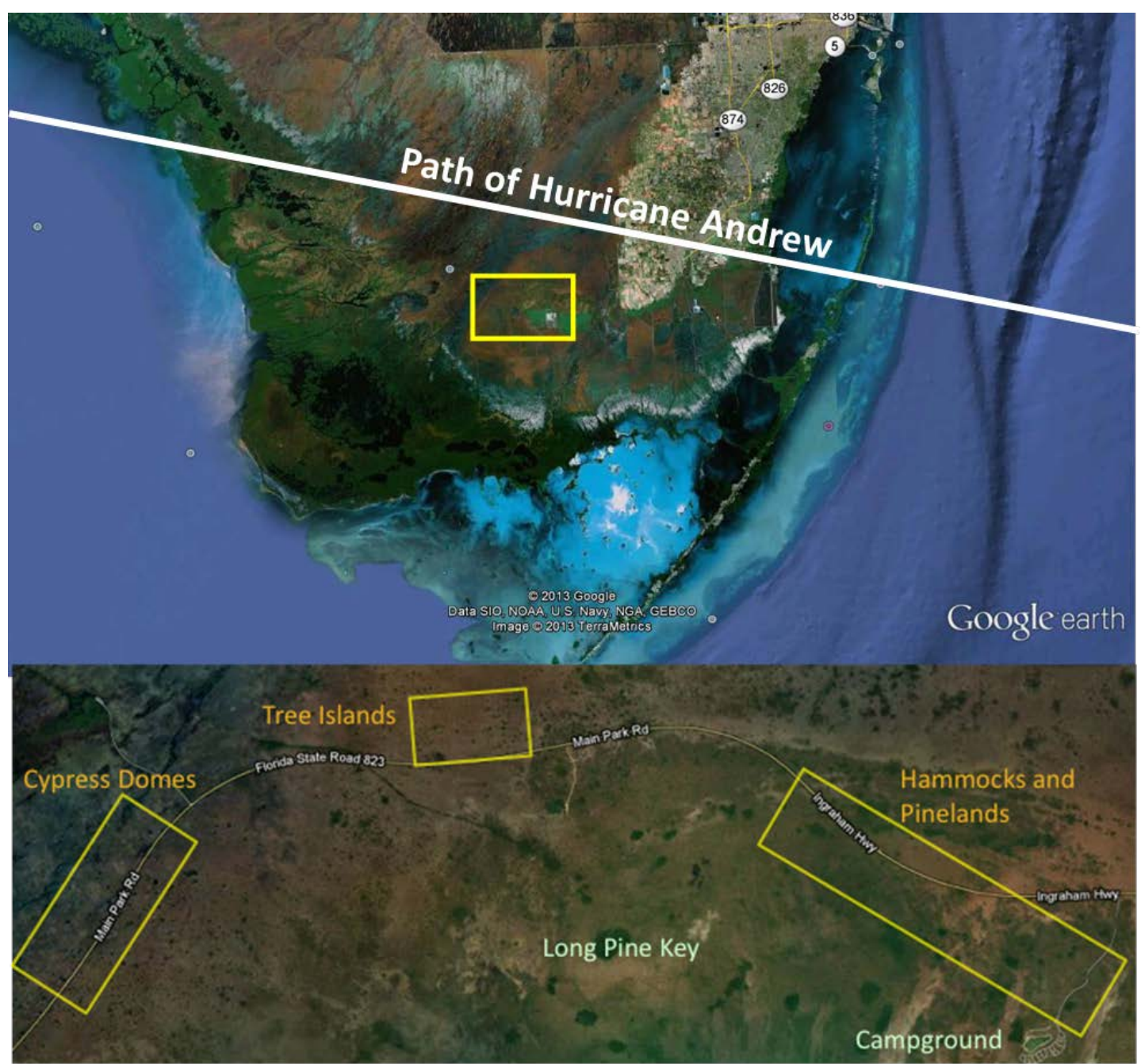

Figure III.1: Upper: Overview of geographic location of all 12 field sites within Everglades National Park. Lower: Specific community positions along Main Park Road 

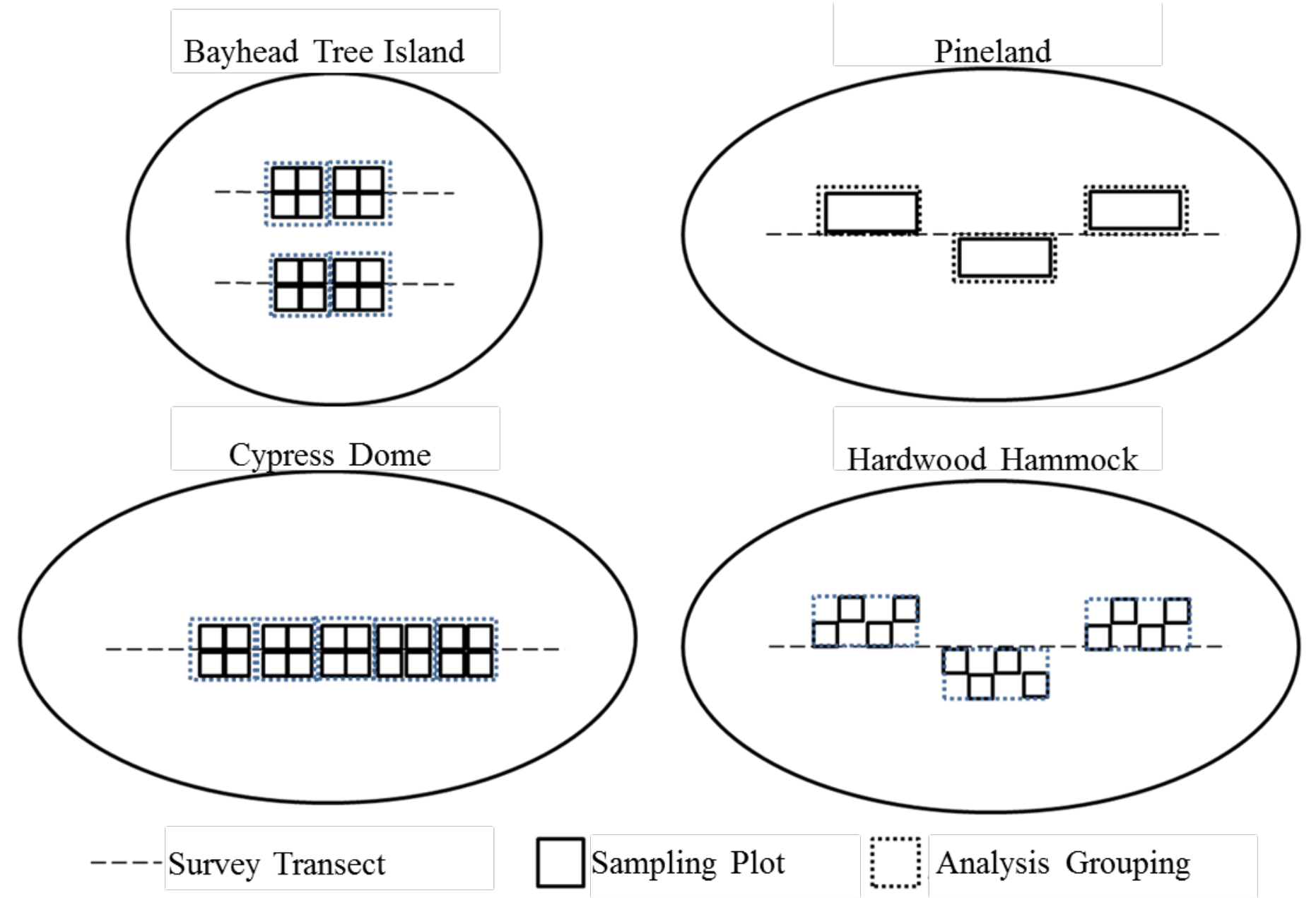

Figure III.2: Diagram of the 5m x 5m survey plots for bayhead tree islands, cypress domes, and hardwood hammocks, and $10 \mathrm{~m} x$ $20 \mathrm{~m}$ survey plots and their orientation along transects within a community, including groupings of survey plots for analysis. 

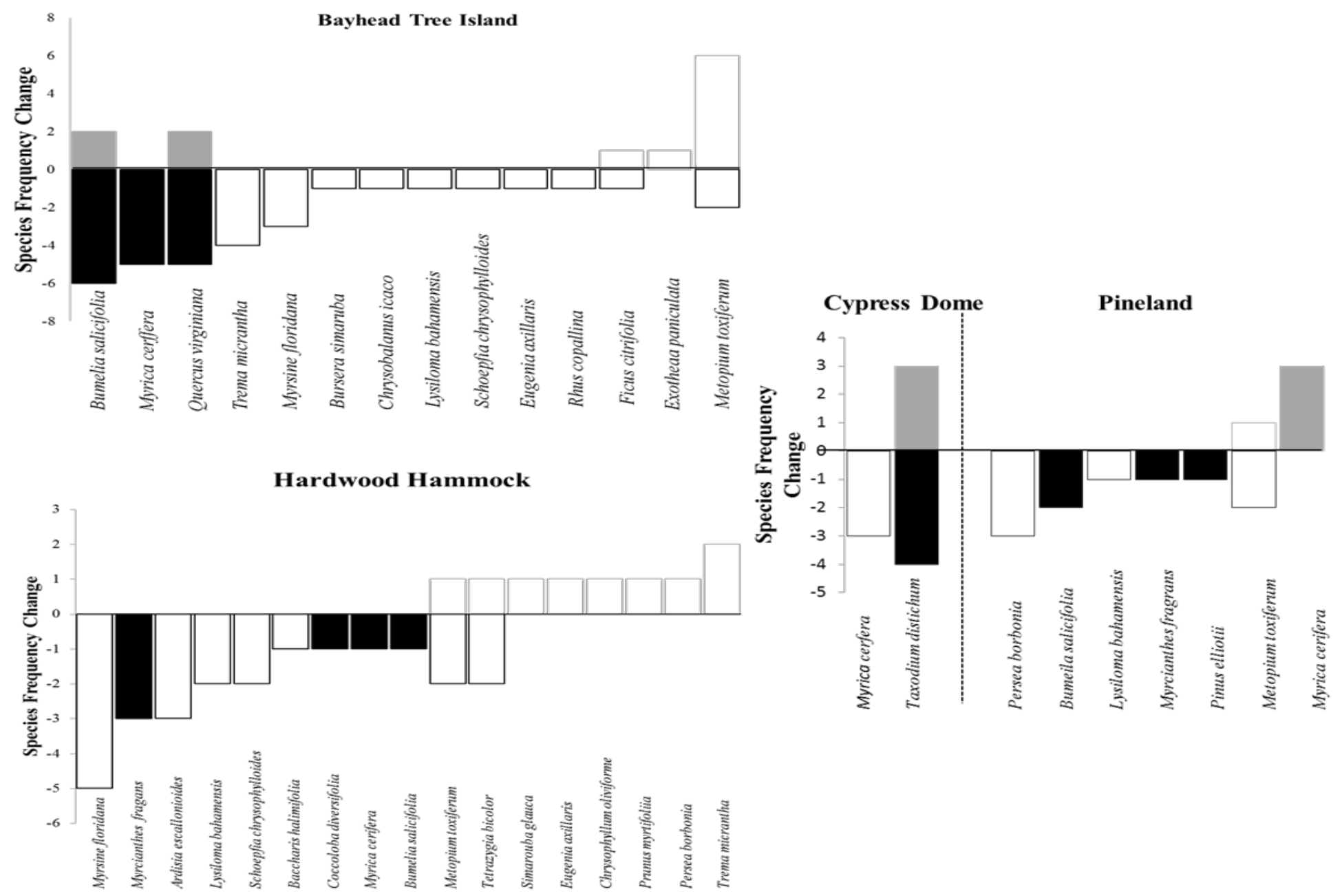

Figure III.3: Individual species loss or gain by plot in each of the four communities in the long-term recovery (20 years) post Hurricane Andrew. Values represent species that had the largest degree of presence change within plots. Bar fill represents species that are either disturbance tolerant (empty fill) or intolerant (solid fill). 

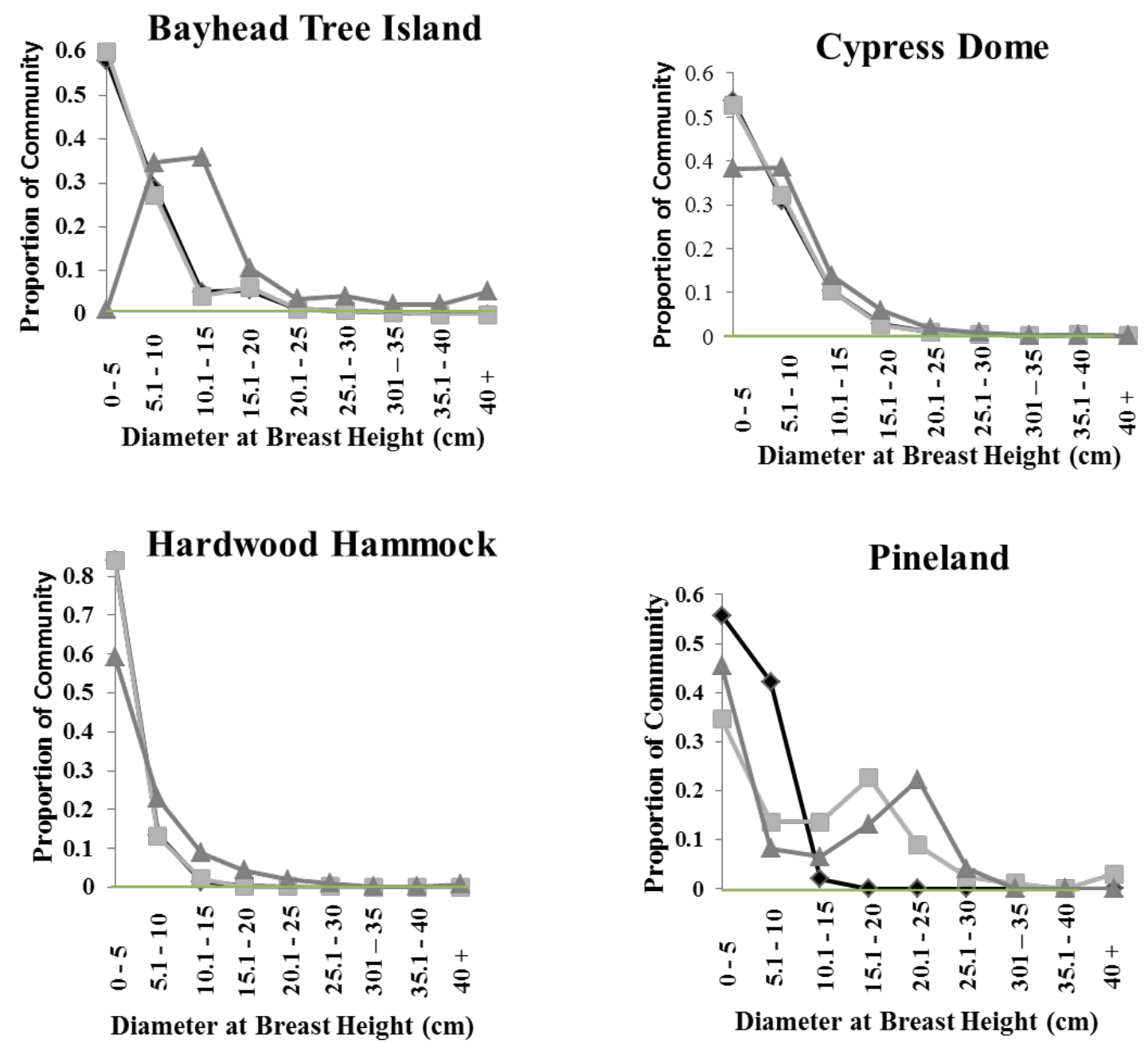

Figure III.4: Number of individuals in each size class (diameter at breast height size, dbh) during pre-hurricane (1993, black diamonds), short-term recovery (1996, light grey squares), and long-term recovery (2012-13, dark grey triangles). 

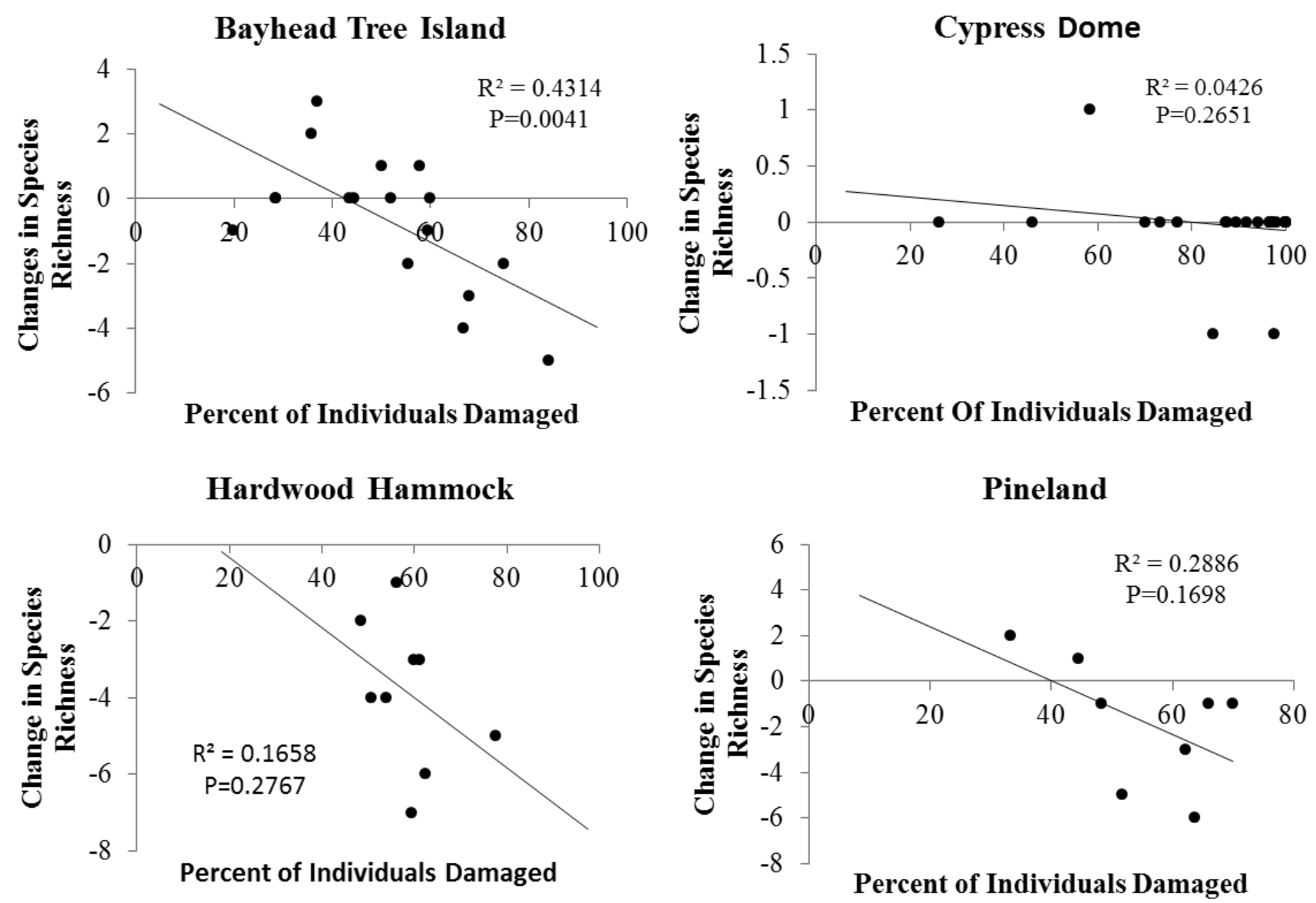

Figure III.5: Change in species richness within four forest communities compared to the percent of individuals damaged within each plot. 
IV: A Predictive Model of Canopy Level Individual Growth Rates after 19 Years of Recovery from Hurricane Andrew

\section{IV.1: Abstract}

Tropical storms are common, widespread disturbances across low-latitude areas that impact both environmentally and economically important forest types. Trees within the path of these storms sustain different degrees of leading to either to mortality or recovery and growth. The ability to predict the growth rate of damaged trees is needed to estimate how fast forest recover and carbon storage. Here I propose a simplified model for predicting long-term, tree growth rate in four dominant Florida Everglades forest communities following damage caused by Hurricane Andrew. The model was developed using data collected 1-3 years after Hurricane Andrew struck southern Florida and used to predicted target individual tree growth over 19 years using initial individual size and damage extent. Taxodium distichum, the dominant species in cypress dome communities, and a mixture of tropical hardwood hammock species were included in development and analysis. Overall the model was effective at predicting growth rate in all four community types and species tested, but estimations of growth rates were species specific and dependent on the initial size of the target individual. The model was most effective at predicting growth rates in Taxodium distichum regardless of an individual's size at the time of Hurricane Andrew's landfall or orientation within the community. The simplified yet effective nature of this model demonstrates that it has the potential to be a powerful tool in predicting the long-term growth rates of trees after hurricane damage. 


\section{IV.2: Introduction}

Tropical storms are large scale, periodic disturbances that alter the species composition and ecosystem function of many low-latitude forest communities worldwide (Lugo 2008). These storms play an important role in shaping forest communities in the South Florida Everglades (Gunderson 1994). Understanding how species and the communities as a whole recover from these storms is paramount to understanding survival in the decades after a storm's impact. The ability to assess species composition and damage level quickly post-storm and to predict subsequent community changes is crucial in predicting the forest structure and function into the future. In this chapter, I use forest community and individual tree attributes to propose a simplified model for predicting individual growth 19 years after Hurricane Andrew for select species in four Everglades forest communities.

Forest damage and ultimate recovery from tropical storms are often vary with community composition and structure (Gilliam et al. 2006; Platt et al. 2000; Platt et al. 2002; Zhang et al. 2006). Storm damage often causes environmental conditions to shift in the short-term and have the potential to shift the competitive landscape within a community (Battaglia 2002; Carlton and Bazzaz 1998; Fernandez and Fetcher 1991; Harmon et al. 1995; Lodge et al. 1991; Ostertag et al. 2003; Xu et al. 1995). Individual damage and changes in abiotic conditions can also shift species composition and growth rates of trees present at the time of disturbance (Denslow et al. 1998; Grubb et al. 1996; Monnier et al. 2013). Even low-diversity communities can be variable in how they 
recover across the landscape and over varying time scales (Baldwin et al. 2006; Piou et al. 200; Xi et al. 2008).

Understanding the dynamics that affect individual tree growth rates and forest community change through time is important to the effective investigation of successional trajectories, forestry, silviculture, and carbon storage (Stage 1973). Tropical and subtropical species, like those that make up a portion of the Everglades forest communities, often show short-term growth rate increases related to shifts in resource availability (Clark and Clark 1994). Growth rates of these tropical species can also be difficult to assess post-hoc compared to those of temperate species due to a lack of tree rings, leading to some difficulty assessing accurate growth rates without long-term, labor intensive field monitoring (Borman and Berlyn 1981). The ability to assess a community post storm using simple methodology and apply accurate growth rate models to individual species would be extremely useful.

Many individual tree-level models of forests focus on shifts in abundances through mortality and recruitment (Condit et al. 1995; Forbosah et al. 2011; Gomes et al. 2003; Sheil and May 1996). Survival and recruitment models also often clump species together in functional groups or by similar taxa to aid in scaling up to the landscape level (Körner 1993). In contrast, growth-rate models focus on individual species and factors that influence that species’ growth (Schumacher et al. 2004). Uriarte et al (2004) found that the most effective model design for predicting individual tree growth after a hurricane included a combination of storm (resource availability) and non-storm (size, competition, etc.) related factors. These models, while accurate, still require labor- and 
time intensive measurements done in the field in order to obtain the data needed to successfully apply them.

Here I propose a simplified model on the basis of visual surveys post Hurricane Andrew for predicting individual tree growth after a 19 year recovery period in Florida Everglades forest communities. I investigated individual tree attributes, neighborhood effects, and storm influences to determine components that were suitable for model development. The model was designed to be applicable across numerous species and community types. This model was then applied to species within four forest community types (hardwood hammocks, cypress domes, pinelands, and bayhead tree islands) and to the community types as a whole (all species included) to determine its effectiveness and applicability within each.

\section{IV.3: Methods}

\section{IV.3.1: Site Description and Field Sampling}

In 1993, forest study sites to document the effects of Hurricane Andrew were established within the Everglades National Park as part of the Hurricane Andrew Recovery Team (HART) (Figure IV.1). Community types within the study system included four non-tidal forest communities: pinelands; hammocks; bayhead tree islands; and cypress domes. Communities were distributed along the Main Park Road due to their

proximity near the eye path of Hurricane Andrew. Three sites were selected within each community type to provide replication (12 total sites). Within each of the sites we established a 100m transect or the length of the study community if less than $100 \mathrm{~m}$ in 
longest dimension. Along each transect 5 x 5m survey plots for hardwood hammocks, bayhead tree islands and cypress domes, and 10 x 20m survey plots for pinelands were established on alternating sides at intervals of 10m (Figure IV.2). Survey plots were later grouped for analysis to create $100 \mathrm{~m}^{2}$ analysis plots in bayhead tree islands, hardwood hammocks, and cypress domes.

Initial surveys (1993) were conducted and each individual tree was assessed for size (diameter at breast height, dbh), species, and visual assessment of damage category associated with the storm (Table IV.1). Subsequent resurveys were conducted in 1996 and 2012-2013 to assess growth, mortality and individual recovery in the short- (1996) and long-term (2012-13) recovery time periods.

\section{IV.3.2: Model Development}

Information collected during the two initial surveys was used in developing the predictive model for long-term growth rates. Species with sufficient frequency of individuals in the study ( $>10)$ and reasonable survival rates ( $>40 \%)$ over the length of the study were selected for inclusion in model development and subsequent testing. Of the species and community types selected, 75\% were used in model development and 25\% was reserved for model testing (Table IV.2). The model was tested on each community as a whole, with all species included, in order to determine its effectiveness. Most of the species were excluded from development/testing due to low frequency and low survival through the study period. Taxodium distichum was selected for model incorporation from the cypress dome communities and Bursera simaruba, Bumelia salicifolia, Eugenia axillaris, Lysiloma bahamensis, and Quercus virginiana from the hardwood hammock 
communities. No species were selected from pinelands due to both low frequency and survival rates. There was considerable overlap of included species in the hardwood hammock and bayhead tree island sites, however survival throughout the duration of the study was not high enough to include individuals from the latter.

To determine variables from the short-term surveys that were significantly related to long-term growth rates, a correlation analysis was conducted using the R statistical environment (R Foundation for Statistical Computing, Vienna, Austria; Table IV.3). Fourteen variables were tested in the correlation analysis with four variables having a significant correlation with long-term growth rates; target size (initial dbh), target damage (numeric scale), average plot damage for all individuals (numeric scale), and nearest neighbor damage (numeric scale). Nearest neighbor damage was excluded from further analysis and model development due to the frequency of individuals near a plot edge rendering it impossible to determine the damage extent of those individuals' nearest neighbor.

Examination of short- and long-term observed growth rates revealed that average growth rates over the short-term sampling period were over twice as fast as those over the long-term period $(0.47$ and $0.21 \mathrm{~cm} \mathrm{dbh/year,} \mathrm{respectively,} \mathrm{n}=610)$. Model construction using short-term growth rates would be required to slow predicted growth over the longterm and it was determined that a damage assessment scale would accomplish this (Table IV.1). This inverted scale demonstrates that the most damaged individuals would have larger values on the new damage numeric scale and less damaged individuals would have lower values. Individuals that had no damage remained at the numeric scale level of zero. 
Preliminary model development produced the equation M1 (shown below) which incorporates two of the remaining short-term variables that demonstrated a significant correlation with long-term growth rates, target size (initial dbh) and average plot individual damage (numeric scale). $\mathrm{S}_{\mathrm{x}}$ represents the size of the individual at each survey ( $S_{1}$ at the initial survey and $S_{19}$ the predicted value after 19 years of growth), $G$ represents the short-term growth rate of that individual ( $\mathrm{dbh} \mathrm{cm} /$ year), $\mathrm{D}_{\mathrm{p}}$ represents the average plot individual damage (numeric scale), and $\mathrm{Y}$ represents the number of years between the initial survey and the size predicted. M1 was relatively accurate in its ability to predict the mean dbh of individuals of all species combined after 19 years of growth using t-test analysis assuming unequal variance performed using R statistical software (average actual $\mathrm{dbh}=13.33 \mathrm{~cm}, \mathrm{M} 1$ predicted $\mathrm{dbh}=8.88 \mathrm{~cm}$, $\mathrm{p}$-value $=0.199$ ). Despite this accuracy of predicted means, the variance of the M1 predictions was much greater than that of the measured individual size after 19 years (M1 variance=114.04 and measured variance $=28.81$ ).

$$
\mathrm{S}_{19}=\mathrm{S}_{1}+\left(\left(\frac{\mathrm{G}}{\mathrm{D}_{\mathrm{p}}}\right) * \mathrm{Y}\right)
$$

To reduce the amount of variance in the model prediction values, the average plot individual damage (numeric scale, $\mathrm{D}_{\mathrm{p}}$ ) was substituted for individual target tree damage values (numeric scale, $\mathrm{D}_{\mathrm{i}}$ ) rendering equation M2 (shown below). Additionally, a community/species specific coefficient (Co) was added that interacts with the short-term growth rate to further make the model appropriate for each application. Species coefficients were determined using non-linear regression package Splind within the R 
statistical environment (R Foundation for Statistical Computing, Vienna, Austria; Table IV.4). M2, using 75\% of data, was expected to more specifically address the individual damage factor that will alter a target individual's growth rate over the long-term time period and reduce the variance in predicted values.

$$
\mathrm{S}_{19}=\mathrm{S}_{1}+\left(\left(\mathrm{Co}_{0} *\left(\frac{\mathrm{G}}{\mathrm{D}_{\mathrm{i}}}\right)\right) * \mathrm{Y}\right)
$$

\section{IV.3.3: Model Testing}

The M2 model was then applied across species and community types, using 25\% of data, that demonstrated enough frequency and survival to determine its accuracy. Predictions of the M2 model was compared with the actual size of individuals after 19 years using a t-test analysis assuming unequal variance performed using the $\mathrm{R}$ statistical environment (R Foundation for Statistical Computing, Vienna, Austria). Further comparisons of the accuracy of M2 in predicting actual individual size were investigated for all species combined and also separated. Taxodium distichum, in particular, was selected for further comparisons, due to its high frequency and survival. Additional model testing included the ability of M2 to predict the 19 year size of individuals of various initial sizes and their proximity to the edge of a cypress dome.

A sensitivity analysis was conducted to determine the effect weight of each variable in M2. This sensitivity analysis consisted of holding all variables constant at their mean value while varying one variable from its mean and increasing that target variable by is standard deviation (up to $+/-4 s d)$. The maximum (M2max) and minimum (M2min) for the M2 solution was then applied to equation SI1 to obtain a Sensitivity 
Index (SI). This process was repeated for each of the four variables present in M2 to determine the Sensitivity Index for each with larger Index values demonstrating a higher sensitivity to a particular variable.

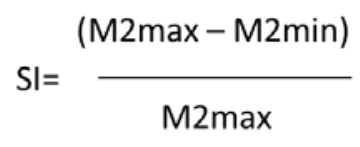

SI1

\section{IV.4: Results}

The M2 model was accurate at predicting individual size for all species combined after 19 years, with the difference between measured and predicted values being very small (Table IV.4; measured $=9.2 \mathrm{~cm}, \mathrm{M} 2=9.3 \mathrm{~cm}, \mathrm{p}=0.964)$. The M2 model was successful in lowering variance across all species (measured=7.7, M2=7.1) compared to M1. There was no significant difference between model predicted size for any of the communities as a whole (all species included). Bayhead tree islands had the largest difference between model and measured values, however this difference was not significant (measured=34.5cm, M2=28.1, $\mathrm{p}=0.416$ ), and hardwood hammocks had the smallest difference (measured $=7.2 \mathrm{~cm}, \mathrm{M} 2=7.3 \mathrm{~cm}, \mathrm{p}=0.983$ ). The $\mathrm{M} 2$ model performed equally well at predicting sizes of Taxodium distichum, the most common species used in the model development (measured $=8.9 \mathrm{~cm}, \mathrm{M} 2=8.2 \mathrm{~cm}, \mathrm{p}=0.792$ ). Within hardwood hammock communities, the accuracy of the model varied by species with none of the six tested species being significantly different.

Residuals analysis revealed the accuracy of the model predictions by target individual initial size (Figure IV.3). Despite the frequency of differences between the 
model predicted and measured values, $96 \%$ of predicted values were within $+/-4 \mathrm{~cm}$ of the measured values, with $84 \%$ being within $+/-2 \mathrm{~cm}$ of measured values. No predicted values were more than $8 \mathrm{~cm}$ different than the measured size values after 19 years. Cypress domes were the community that had the highest number individuals both in model development and testing (Figure IV.4). Pinelands and cypress domes were mixed in the number of individuals that were over and underestimated by the model.

Hardwood hammock species showed species specific differences between predicted and measured individual size (Figure IV.5). Most species were mixed between the model over and underestimating target individual size after 19 years. All species, except $Q$. virginiana, all had initial less than $10 \mathrm{~cm}$ dbh and differences between model predicted and measured values less than $+/-2 \mathrm{~cm}$. Quercus virginiana had the largest individuals at the onset of the study and all of the predicted and measured value differences were larger than any other species.

Application of the M2 model to individual species shows that the model was effective at predicting growth of $T$. distichum across all initial individual sizes (Figure IV.6). Applying the model to T. distichum results in 99\% of individuals being accurately predicted within $+/-4 \mathrm{~cm}$ and $86 \%$ of individuals' size accurately predicted within $+/$ 2cm. At the time of initial sampling (1993), 141 of 167 Taxodium distichum individuals occupied the lowest size class, $0-10 \mathrm{~cm}$ dbh. Model application showed larger differences between predicted and measured size after 19 years in individuals initially occupying the 0-10cm dbh size class compared to all others. Out of the 141 individuals occupying the 010cm size class, $99 \%$ were accurately predicted within +/- 4cm dbh, with $96 \%$ within +/- 
2cm dbh. The model was less accurate at predicting the growth of individuals with initial sizes $>10 \mathrm{~cm}$ dbh with $19 \%$ (5/26) individuals overestimated by more than $2 \mathrm{~cm}$ dbh. M2 model application to Taxodium distichum individuals with regards to their placement within a cypress dome community showed a consistent spread of model effectiveness (Figure IV.7). The individuals that were overestimated $>2 \mathrm{~cm}$ dbh by the model were spread throughout the community from dome edge.

The M2 model showed differences in sensitivity to each of the component variables after sensitivity analysis (Table IV.5). Visual damage estimates of individuals directly following Hurricane Andrew $\left(\mathrm{D}_{\mathrm{i}}\right)$ had the least effect on the final solution (SI=0.07) while short -term growth rate $(1993-96, \mathrm{G})$ had the most effect $(\mathrm{SI}=0.39)$. The size of a target individual at the time of the intial study survey $\left(1993, \mathrm{~S}_{1}\right.$ ) also had large effect on the final M2 model solution (SI=0.23).

\section{IV.5: Discussion}

As a result of low survival rates and species frequency, only a subset of the data collected during the initial hurricane damage survey was able to be used in model development. Individual size and storm damage level, both of the target individual and of the target individual's neighbors, were shown to be the strongest correlates of subsequent growth. Individual size has a clear influence on future growth rates as growth slows as a tree accumulates biomass that requires increasing caloric investment to maintain. Storm damage levels also impact growth rates post-hurricane, with the recovery (e.g. wound healing, bud formation, leaf regrowth) from this damage requiring calories that could otherwise be put toward normal growth processes. High levels of storm-related damage 
can also lower an individual's ability to compete and possibly increase its susceptibility to other stress, resulting in deviations from its potential growth rate. The importance of a combination of individual size and damage extent is consistent with the findings of Uriarte et al. (2004) in which the best components for model development were a combination of hurricane and non-hurricane related influences.

Most of the species surveyed during the initial HART community assessments were not candidates for inclusion in the model development and testing due to low individual frequencies or low survival rates over the period of the 19 year study, with only 6 out of 27 species included. No individuals from bayhead tree islands or pinelands were included in model analysis due to the low survival of the species within these communities across the length of the study. Community specific results for tests of model effectiveness were varied by community type however the model was accurate in estimating size in all of them after 19 years. Cypress dome communities had the best model applicability as a result of high frequencies and survival of the dominant species, Taxodium distichum. Despite having high overall diversity, hardwood hammocks had many species that were too infrequent to be included in analysis.

The M2 model applicability to individuals within the hardwood hammocks was mixed due to the diversity of species within them. Species to which the model was effectively applied showed that overall the model overestimated long-term growth rates. The remaining species that were included in model analysis were comprised of a broad variety of life histories, including slow-growing temperate species (e.g., Quercus virginiana), fast-growing tropical species (e.g., Bursera simaruba), and tall shrub species 
(e.g., Bumelia salicifolia). The diversity of species and life histories may have led to larger discrepancies between predicted and measured growth rates for the species.

The model accurately predicted long-term growth rates; however, as with species from the hardwood hammock community, these rates were species specific. In tests for model robustness across size classes of $T$. distichum, the model was shown to be effective across all classes, although there were larger differences between measured and predicted values in the largest individuals. The magnitude of these differences may have been influenced by higher densities of stems and varying levels of damage extent, resulting in other factors influencing individual growth rates. Stem density and damage extent are likely also affected by the orientation of an individual within a community (e.g. distance from edge of cypress dome). Regardless of an individual's orientation within a cypress community, the model was equally effective in predicting growth. The model is highly applicable and effective in Taxodium distichum-dominated communities. Understanding the recovery of cypress communities is important due to their wide range across the southern United States, vulnerability to hurricane impact, and economic importance.

Sensitivity analysis on the M2 model demonstrated that individual size at the time of initial survey (1993) and short-term growth rate (1993-96) had a larger influence on model predictions than did the visually estimated damage extent. Initial individual size likely has an effect on growth rate, both in the short- and long-term recovery periods, causing the model component variable and final predictive size estimation to be linked. Visual estimations of hurricane damage have some subjectivity and differences in damage extents across size classes could influence the final M2 predictive values. 
This model based on individual size and damage extent shows promise for research and management of hurricane- impacted forests. The simplicity of the model, compared to previous growth models, allows its components to be quickly assessed directly after a storm occurs with data collection more inexpensively applied to much larger areas of monitoring. The ease of use and accuracy, especially in cypress communities, could be a powerful tool in predicting how communities recover post hurricane. The proposed M2 model warrants further application in other communities to test its validity within other ecosystems.

\section{IV.6: References}

Baldwin, A., M. Egnotovich, M. Ford, W. Platt. 2001. "Regeneration in fringe mangrove forests damaged by Hurricane Andrew.” Plant Ecology 157: 151-164.

Battaglia, L. L., S. A. Fore, R. R. Sharitz. (2001). "Seedling emergence, survival and size in relation to light and water availability in two bottomland hardwood species.” Journal of Ecology. 88(6):1041-1050.

Bormann, F.H., and G. Berlyn. 1981. "Age and growth rate of tropical trees: New directions for research.” School of forestry and Environmental Studies. Yale University, New Haven, Connecticut, USA.

Carlton, G. C. and F. A. Bazzaz. (1998). "Resource congruence and forest regeneration following an experimental hurricane blowdown.” Ecology 79:1305-1319.

Clark, A.C., and D. B. Clark. 1999. "Assessing the growth of tropical rain forest trees: Issues for forest modeling and management.” Ecological Applications. 9(3): 981-997.

Condit, R., S. P. Hubbell, et al. 1995 "Mortality rates of 205 neotropical trees and shrub species and the impact of severe drought.” Ecological Monographs. 65(4): 419-439.

Denslow J. S., A. M. Ellison, R. E. Sanford. (1998). “Treefall gap size effects on aboveand below-ground processes in a tropical wet forest.” Journal of Ecology 86(4): 597-609.

Downing, D. J., Gardner, R. H., and Hoffman, F. O. (1985). “An examination of response surface methodologies for uncertainty analysis in assessment models.” Technometrics, 27(2): 151-163. 
Fernandez, D.S. and N. Fetcher. (1991). "Changes in Light Availability Following Hurricane Hugo in a Subtropical Montane Forest in Puerto Rico.” Biotropica 23(4a): 393-399.

Forbosah, P. F., T. C. H. Sunderland, et al. 2011. "Tree population dynamics of three altitudinal vegetation communities on Mount Cameroon (1989-2004).”Journal of Mountain Science. 8: 495-504.

Gilliam, F. S., W. J. Platt, et al. (2006). "Natural disturbances and the physiognomy of pine savannas: A phenomenological model." Applied Vegetation Science 9(1): 83-96.

Gomes, E. P. C., W. Mantovani, et al. 2003. "Mortality and recruitment of trees in a secondary montane rain forest in southeastern Brazil.” Brazilian Journal of Biology. 63(1): 47-60.

Grubb, P. J., W. G. Lee, et al. (1996). "Interaction of irradiance and soil nutrient supply on growth of seedlings of ten European tall-shrub species and Fagus sylvatica." Journal of Ecology. 84:827-840.

Gunderson, L. H. (1994). "Vegetation of the Everglades: Determinants of Community Composition.” Everglades:The Ecosystem and Its Restoration. S. M. Davis and J. C. Ogden eds. CRC Press.

Harmon, M. E., D. F. Whigham, et al. (1995). "Decomposition and mass of woody detritus in the tropical dry forests of the northeastern Yucatan Peninsula, Mexico.” Biotropica. 27(3):305-316.

Körner, C. 1993. "Scaling from species to vegetation: The usefulness of functional groups” Biodiversity and Ecosystem Function. Eds. E.-D. Shulze and H. A. Mooney. Springer-Verlag, New York, New York, USA.

Lodge, D. J., F. N. Scatena, et al. (1991). "Fine Litterfall and Related Nutrient Inputs Resulting from Hurricane Hugo in Subtropical Wet and Lower Montane Rain Forests in Puerto Rico.” Biotropica. 23(4a):336-342

Lugo, A. E. 2008. Visible and invisible effects of hurricanes on forest ecosystems: An international review. Austral Ecology 33:368-398.

Monnier, Y., A. Bousquet-Melou, et al. (2013) "How nutrient availability influences acclimation to shade of two (pioneer and late-successional) Mediterranean tree species?” European Journal of Forest Restoration. 132:325-333.

Ostertag, R., F. N. Scatena, et al. (2003). "Forest floor decomposition following hurricane litter inputs in several Puerto Rican forests.” Ecosystems. 6(3):261-273. 
Piou, C., I. C. Feller, U. Berger, F. Chi. 2006. “Zonation patterns of Belizean offshore mangrove forests 41 years after a catastrophic hurricane.” Biotropica. 38: 365-374.

Platt, W. J., B. Beckage, et al. (2002). "Interactions of large-scale disturbances: Prior fire regimes and hurricane mortality of savanna pines." Ecology 83(6): 1566-1572.

Platt, W. J., R. F. Doren, et al. (2000). "Effects of Hurricane Andrew on stands of slash pine (Pinus elliottii var. densa) in the everglades region of south Florida (USA)." Plant Ecology 146(1): 43-60.

Sheil, D., and R. May. 1996. "Mortality and recruitment rate evaluations in heterogeneous tropical forests.” Journal of Ecology. 84: 91-100.

Shumacher, S., H. Bugmann, D. J. Mladenoff. 2004. "Improving the formulation of tree growth and succession in a spatially explicit landscape model.” Ecological Modelling. 180: 175-194.

Stage, A. R. 1973. “Prognosis model for stand development.” USDA Forest Service. Research Paper INT-137.

Uriarte, M., Canham, C. D., et al. 2004. "A neighborhood analysis of tree growth and survival in a hurricane-driven tropical forest.” Ecological Monographs. 74(4): 591-614.

Xi, W., R. K. Peel, D. L. Urban. 2008 "Changes in forest structure, species diversity and spatial pattern following hurricane disturbance in a Piedmont North Carolina forest, USA.” Journal of Plant Ecology. 1:43-57.

Xu, X. N., E. Hirata, et al. (2004). "Effect of typhoon disturbance on fine litterfall and related nutrient input in a subtropical forest on Okinawa Island., Japan.” Basic and Applied Ecology. 5(3):271-282.

Zhang, K. Q., M. Simard, et al. (2008). "Airborne laser scanning quantification of disturbances from hurricanes and lightning strikes to mangrove forests in Everglades National Park, USA." Sensors 8(4): 2262-2292. 
Table IV.1: Damage assessment from initial community surveys and model parameter numeric categories for all individuals.

\begin{tabular}{ccl}
\hline $\begin{array}{c}\text { Damage } \\
\text { Assessment } \\
\text { Numeric } \\
\text { Category }\end{array}$ & $\begin{array}{c}\text { Model } \\
\text { Parameter } \\
\text { Numeric } \\
\text { Category }\end{array}$ & \multicolumn{1}{c}{ Damage Type } \\
\hline 0 & 0 & No damage \\
1 & 5 & Tip Up \\
2 & 4 & Trunk Snap Off \\
3 & 3 & Major Branch Damage \\
4 & 2 & Minor Branch Damage \\
5 & 1 & Bent Branches \\
\hline
\end{tabular}


Table IV.2: Survival rates of tagged individuals between 1993 and 2012-13, number of individuals included as parameter components for model development, and number of individuals included in model performance testing. Species included in development and testing were required to have 40\% survival between 1993 and 2012-13 and more than 10 individuals surviving.

\begin{tabular}{|c|c|c|c|c|c|}
\hline & \multicolumn{3}{|c|}{ Tagged Individuals } & \multicolumn{2}{|c|}{ Model } \\
\hline & \multicolumn{3}{|c|}{2012} & \multirow[b]{2}{*}{ Component } & \multirow[b]{2}{*}{ Test } \\
\hline & 1993 & 2013 & $\%$ Survival & & \\
\hline Study Total & 1747 & 930 & 53 & 610 & 205 \\
\hline \multicolumn{6}{|c|}{ Bayhead Tree Island } \\
\hline Total & 235 & 24 & 10 & 18 & 6 \\
\hline Bursera simaruba & 15 & 4 & 27 & - & - \\
\hline Bumelia salicifolia & 23 & 8 & 35 & - & - \\
\hline Chrysobalanus icaco & 2 & 0 & 0 & - & - \\
\hline Cephalanthus occidentalis & 1 & 0 & 0 & - & - \\
\hline Eugenia axillaris & 10 & 1 & 10 & - & - \\
\hline Ficus spp & 13 & 2 & 15 & - & - \\
\hline Ilex cassine & 11 & 0 & 0 & - & - \\
\hline Lysiloma bahamensis & 24 & 5 & 21 & - & - \\
\hline Myrica cerifera & 5 & 0 & 0 & - & - \\
\hline Myrsine floridana & 4 & 0 & 0 & - & - \\
\hline Metopium toxiferum & 11 & 4 & 36 & - & - \\
\hline Quercus virginiana & 35 & 0 & 0 & - & - \\
\hline Schoepfia chrysophylloides & 1 & 0 & 0 & - & - \\
\hline Trema micrantha & 75 & 0 & 0 & - & - \\
\hline Unknown & 5 & 0 & 0 & - & - \\
\hline
\end{tabular}

Table IV. 2 continued...

\begin{tabular}{|c|c|c|c|c|c|c|}
\hline & \multicolumn{3}{|c|}{ Tagged Individuals } & \multicolumn{3}{|c|}{ Model } \\
\hline & & $2012-$ & & & & \\
\hline & 1993 & 2013 & \% Survival & Component & Test & \\
\hline \multicolumn{7}{|c|}{ Pine Rockland } \\
\hline Total & 201 & 19 & 9 & 14 & & 5 \\
\hline Bumelia celastrina & 2 & 0 & 0 & - & & - \\
\hline Bumelia salicifolia & 10 & 0 & 0 & - & & - \\
\hline Forestiera pinetorum & 1 & 0 & 0 & - & & - \\
\hline Ilex cassine & 6 & 0 & 0 & - & & - \\
\hline Lysiloma bahamensis & 1 & 0 & 0 & - & & - \\
\hline
\end{tabular}




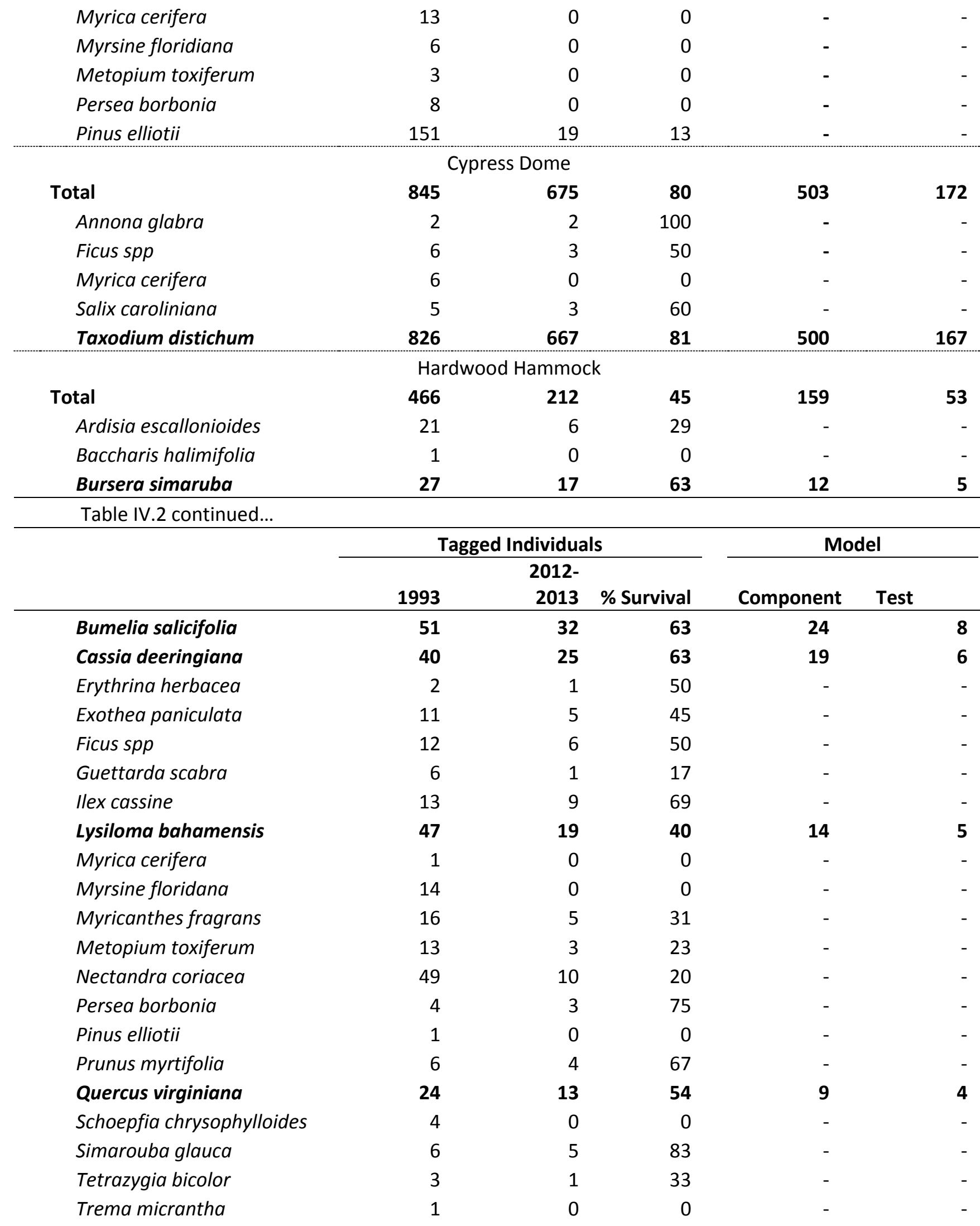


Table IV.3: Model Parameter category for all species across all communities with $\mathrm{R}^{2}$ and statistical significances from correlation analysis.

\begin{tabular}{llrrr}
\hline Parameter & Slope & Intercept & R2 & P \\
\hline Target Size (initial dbh) & $\mathbf{1 . 4 0}$ & $\mathbf{1 . 2 0}$ & $\mathbf{0 . 6 4 2}$ & $<\mathbf{0 . 0 0 1}$ \\
Target Size Category (large/small) & $\mathbf{1 . 2 9}$ & $\mathbf{1 . 9 8}$ & $\mathbf{0 . 3 3 2}$ & $\mathbf{0 . 0 3 1}$ \\
Target Damage (numeric scale) & $\mathbf{1 . 5 6}$ & $\mathbf{1 . 5 8}$ & $\mathbf{0 . 2 2 7}$ & $\mathbf{0 . 0 4 0}$ \\
Target Damage Category (high/low) & -1.33 & 7.46 & 0.010 & 0.362 \\
Target Recovery (numeric scale) & -1.10 & 7.82 & 0.022 & 0.177 \\
Average Individual Size in Plot (dbh) & 2.10 & 2.31 & 0.096 & 0.072 \\
Target Size Compared to Plot Average Size & & & & \\
(larger/smaller) & -8.48 & 18.47 & 0.099 & 0.110 \\
Plot Diversity (species richness) & -0.06 & 6.24 & 0.000 & 0.844 \\
Target Proximity to Nearest Neighbor (meters) & 3.00 & 4.93 & 0.015 & 0.265 \\
Nearest Neighbor Damage (numeric scale) & $\mathbf{- 0 . 6 1}$ & 7.91 & $\mathbf{0 . 1 5 1}$ & $\mathbf{0 . 0 4 7}$ \\
Nearest Neighbor Damage Category (high/low) & -0.26 & 6.22 & 0.000 & 0.812 \\
Nearest Neighbor Size (dbh) & -0.17 & 6.28 & 0.007 & 0.430 \\
Nearest Neighbor Size Category (large/small) & -0.70 & 6.56 & 0.001 & 0.695 \\
Nearest Neighbor Conspecific to Target (yes/no) & -1.98 & 8.10 & 0.018 & 0.212 \\
\hline
\end{tabular}


Table IV.4: Number of individuals and model M2 coefficients for each species included in model performance testing with actual size after 19 years of growth (2012-13) and model predicted size. * denotes p-value $<0.05$ as a result of t-test analysis

\begin{tabular}{lrrrrrrr}
\hline \multicolumn{1}{c}{ Species } & $\mathrm{n}$ & $\begin{array}{c}\text { Model } \\
\text { Coefficient }\end{array}$ & $\begin{array}{c}\text { Actual } \\
\text { Size } \\
\text { (cm) }\end{array}$ & Variance & $\begin{array}{c}\text { Model } \\
\text { Predicted } \\
\text { (cm) }\end{array}$ & Variance & Difference \\
\hline Total & $\mathbf{2 3 6}$ & $\mathbf{1 . 0 1 7}$ & $\mathbf{9 . 2}$ & $\mathbf{7 . 7}$ & $\mathbf{9 . 3}$ & $\mathbf{7 . 1}$ & $\mathbf{- 0 . 1}$ \\
Bayhead Tree Island & $\mathbf{6}$ & $\mathbf{1 . 4 2 0}$ & $\mathbf{3 4 . 5}$ & $\mathbf{1 8 . 1}$ & $\mathbf{2 8 . 1}$ & $\mathbf{1 6 . 3}$ & $\mathbf{+ 6 . 4}$ \\
Pineland & $\mathbf{5}$ & $\mathbf{1 . 7 2 1}$ & $\mathbf{1 7 . 5}$ & $\mathbf{3 . 7}$ & $\mathbf{1 7 . 0}$ & $\mathbf{5 . 5}$ & $\mathbf{- 0 . 5}$ \\
Cypress Dome & $\mathbf{1 7 2}$ & $\mathbf{0 . 8 9 2}$ & $\mathbf{7 . 8}$ & $\mathbf{1 4 . 6}$ & $\mathbf{8 . 1}$ & $\mathbf{1 4 . 8}$ & $\mathbf{+ 0 . 3}$ \\
$\quad$ Taxodium distichum & 167 & 0.926 & 8.9 & 14.3 & 8.2 & 14.9 & $\mathbf{+ 0 . 7}$ \\
Hardwood Hammock & $\mathbf{5 3}$ & $\mathbf{0 . 9 1 4}$ & $\mathbf{7 . 2}$ & $\mathbf{1 7 . 1}$ & $\mathbf{7 . 3}$ & $\mathbf{1 9 . 2}$ & $\mathbf{- 0 . 1}$ \\
$\quad$ Bursera simaruba & 5 & 0.961 & 12.9 & 5.5 & 13.3 & 4.8 & +0.4 \\
$\quad$ Bumelia salicifolia & 8 & 0.937 & 10.5 & 5.4 & 11.8 & 2.7 & -1.3 \\
Eugenia axillaris & 10 & 0.987 & 5.8 & 3.5 & 5.6 & 1.8 & -0.2 \\
Lysiloma bahamensis & 5 & 0.983 & 11.5 & 6.7 & 11.0 & 1.6 & -0.5 \\
Quercus virginiana & 4 & 0.934 & 37.6 & 6.5 & 39.6 & 9.1 & +2.0 \\
\hline
\end{tabular}


Table IV.5: M2 model variable averages (Ave) and standard deviations (SD), including sensitivity analysis maximum (Max) and minimum (Min) solutions with Sensitivity Index (SI).

\begin{tabular}{lrrrrr}
\hline & Ave & SD & Min & Max & SI \\
\hline Starting Size $\left(\mathrm{S}_{1}\right) \mathrm{cm}$ dbh & 5.81 & 0.33 & 8.77 & 11.41 & 0.23 \\
Short-term Growth (G) cm yr ${ }^{-1}$ & 0.57 & 0.08 & 7.63 & 12.55 & 0.39 \\
Damage (Di) & 2.53 & 0.06 & 9.74 & 10.51 & 0.07 \\
Year (Y) & 19 & na & na & na & na \\
\hline
\end{tabular}




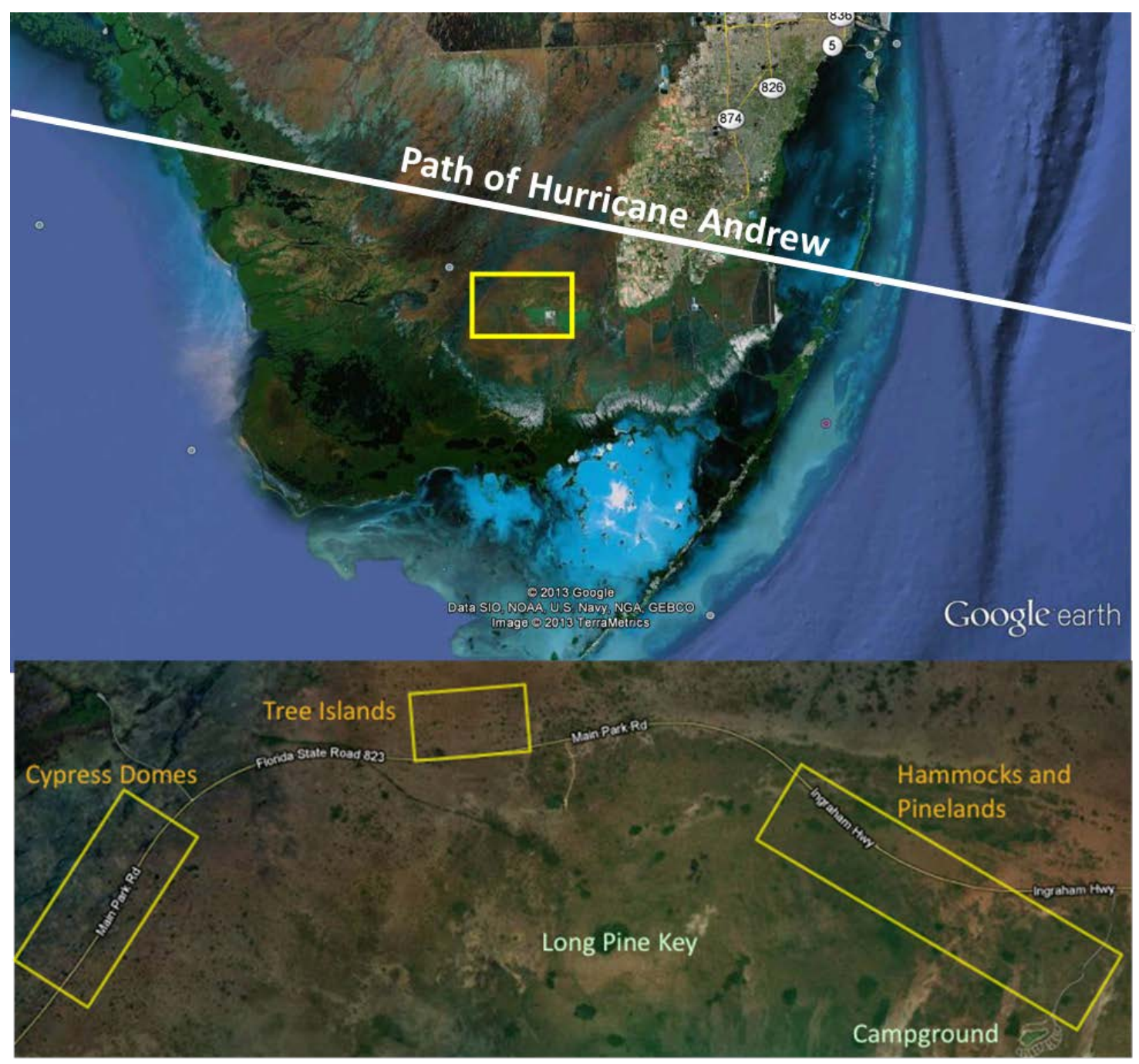

Figure IV.1: Upper: Overview of Geographic location of all 12 field sites within Everglades National Park. Lower: Specific community positions along Main Park Road. 


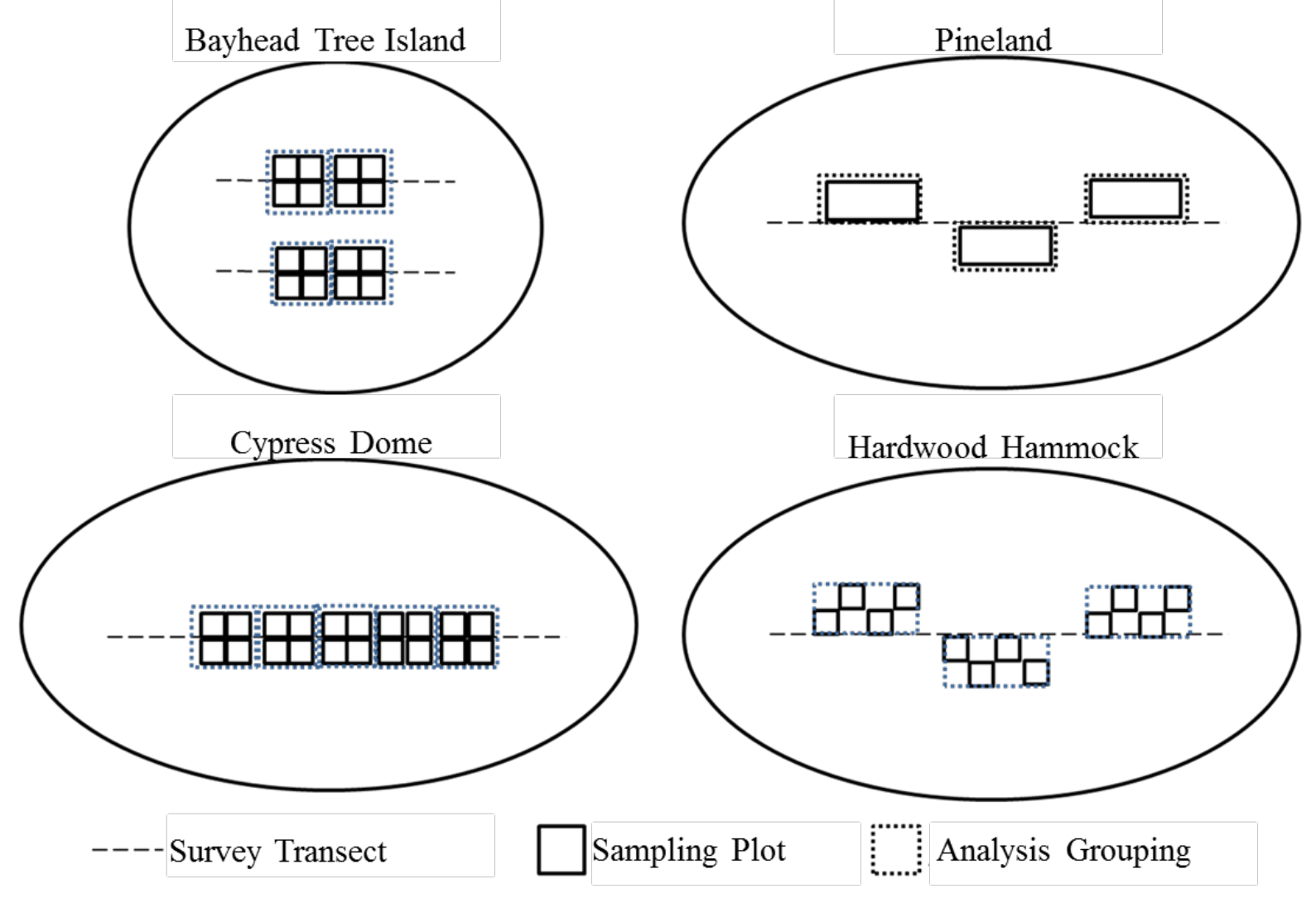

Figure IV.2: Diagram of the $5 \mathrm{~m}$ x 5m survey plots for bayhead tree islands, cypress domes, and hardwood hammocks, and $10 \mathrm{~m} x$ $20 \mathrm{~m}$ survey plots and their orientation along transects within a community, including groupings of survey plots for analysis. 


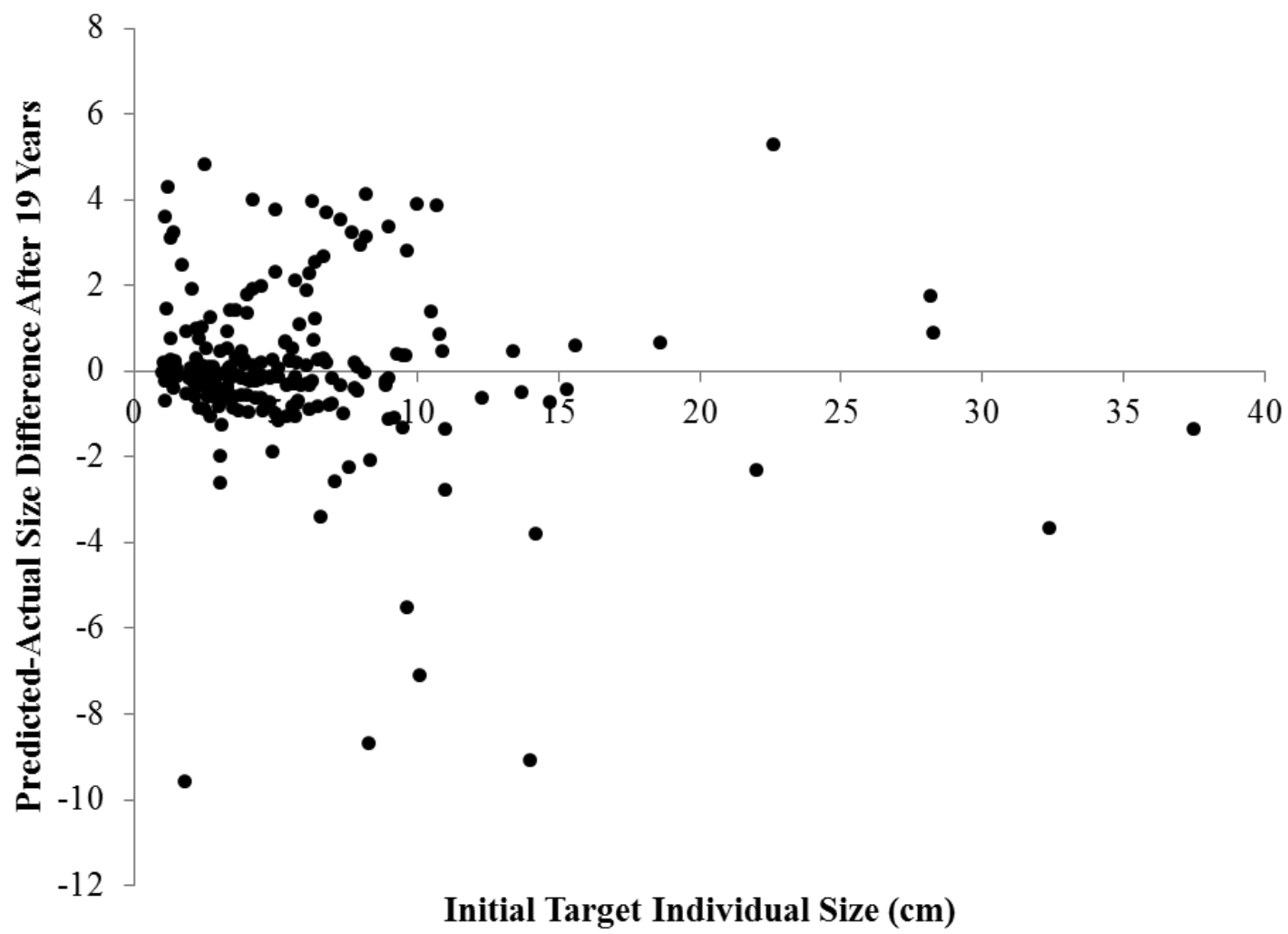

Figure IV.3: Difference between actual individual sizes after 19 years (2012-13) and predicted M2 model size for all species included in model performance testing grouped by the target individual's initial size (1993). 

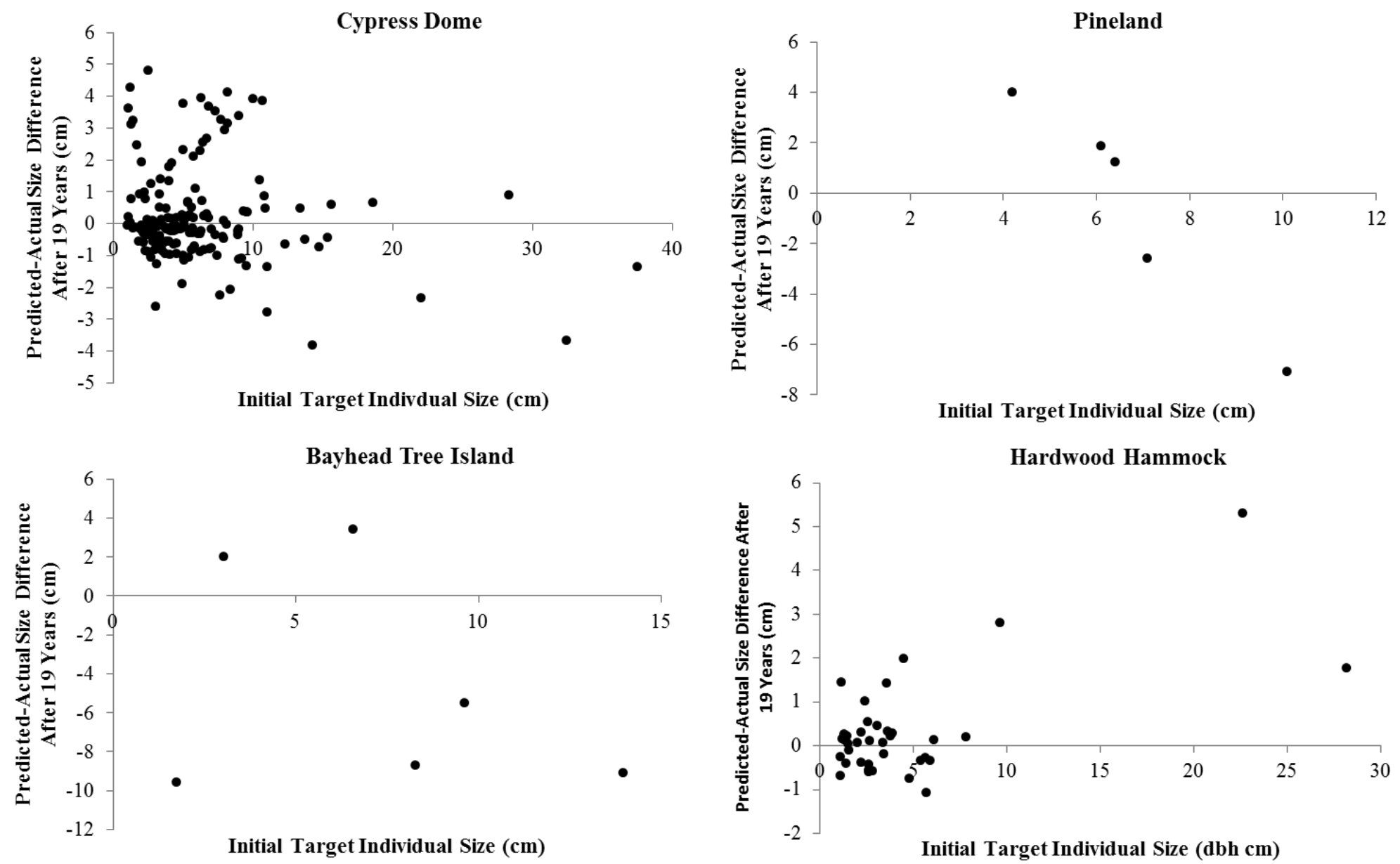

Figure IV.4: Difference between actual individual sizes after 19 years (2012-13) and predicted M2 model size for individuals within each of the four study communities grouped by the target individual's initial size (1993). 


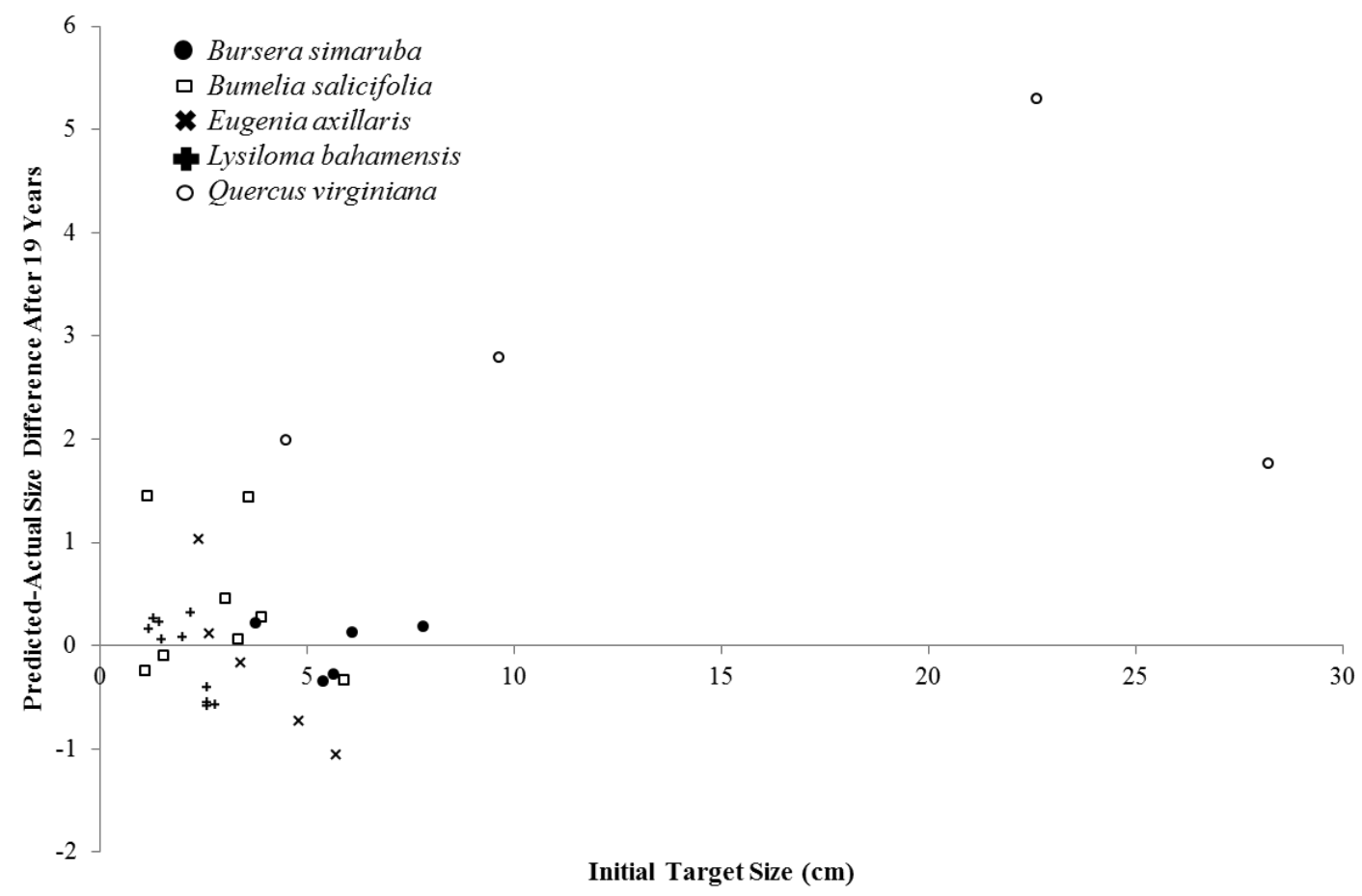

Figure IV.5: Difference between actual individual sizes after 19 years (2012-13) and predicted M2 model size for all hardwood hammock species included in model performance testing grouped by the target individual's initial size (1993). 


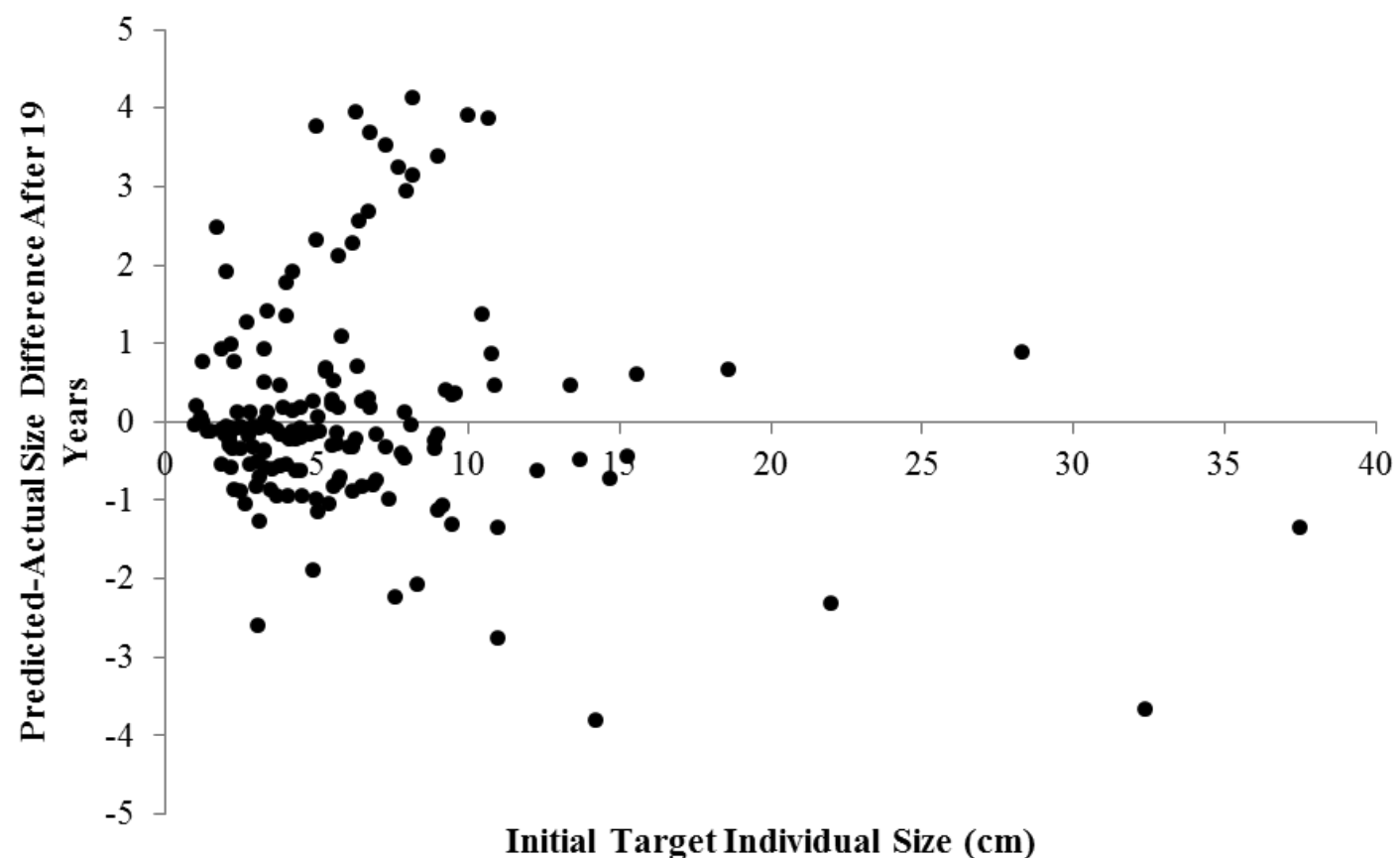

Figure IV.6: Difference between actual individual sizes after 19 years (2012-13) and predicted M2 model size for Taxodium distichum included in model performance testing (no unit on $\mathrm{x}$-axis as a result of being arranged by individual tree tag number). 


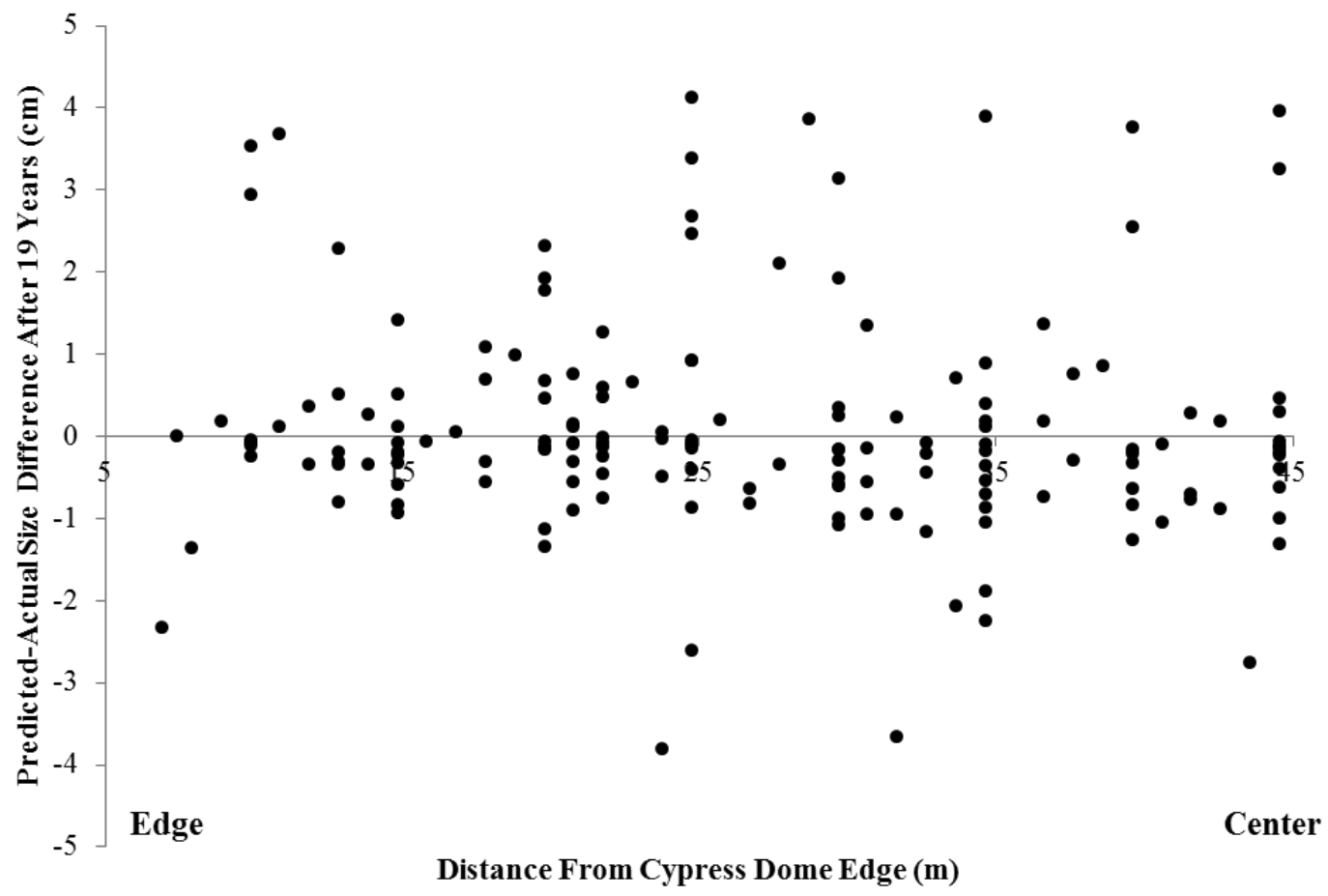

Figure IV.7: Difference between actual individual sizes after 19 years (2012-13) and predicted M2 model size for Taxodium distichum based on individual position within the cypress dome included in model performance testing. 
V: Growth Rate and Resource Allocation Responses of Canopy Species Seedlings from Four Everglades Plant Communities to Varying Light and Nutrient Regimes

\section{V.1: Abstract}

Tropical storm-associated damage is a periodic occurrence in coastal forests around much the world and particularly in the Florida Everglades. Wind damage associated with hurricanes can devastate the forest canopy, strongly altering environmental conditions in the understory that affect seedling growth and canopy regeneration. These include large changes in light and increased soil nutrients as a result of canopy removal. I conducted a two-way factorial light and nutrient manipulation study to investigate the role of different levels of light and nutrient resources on seedling growth of four dominant canopy species in the Everglades, Taxodium distichum, Pinus elliottii, Quercus virginiana, and Bursera simaruba. Light levels ranged from full sun to $50 \%$ shade and nutrient levels from no addition to 1.5g phosphorus and 3g nitrogen/liter water addition. In addition to these treatments, a subset of individuals from each species was subjected to a simulated hurricane treatment mimicking the effects of canopy opening from defoliation and the corresponding nutrient pulse to plants from the forest seedling bank. Responses to environmental conditions were species specific; however, growth rates and biomass accumulation responded more to changes in soil nutrient levels than to changes in light levels. Tissue biomass allocation was similar across most treatments for all species except Q. virginiana, which altered its above- and belowground biomass allocation. Leaf nitrogen concentrations were lowest in low nutrient, low light conditions for all species; however, they significantly increased with simulated hurricane treatment. Differences in $\delta^{13} \mathrm{C}$ were showed no clear trend across species and 
were mixed across treatments and after hurricane simulation. The hurricane simulation treatment increased growth rates and biomass accumulation overall with the largest increases present in $Q$. virginiana and $B$. simaruba. Our results suggest that the adaptive traits of species affect the plasticity necessary to adjust to changing environmental conditions and ultimately the ability of a species to recolonize canopy gaps.

\section{V.2: Introduction}

Hurricanes, tropical storms, and their remnants impact many coastal regions all over the world and are a periodic disturbance phenomenon in the Florida Everglades. These storms produce widespread devastation on the forests of the Everglades system (Boose et al. 1994; Stanturf et al. 2007; Zimmerman 1994). Storm damage, and the resulting shifts in environmental conditions, has the potential to shift successional trajectories (Everham and Brokaw 1996; Gunderson 2000). Understanding the impacts of hurricanes and how forests respond to them is important to predicting forest structure and community composition in the long-term. Although there have been field studies of tree response to post-hurricane environments in the Everglades (Platt et al. 2000; Whelan 1997), no studies have investigated the response of the dominant Everglades tree species under controlled conditions and individual species responses to the light and nutrient regimes that follow in a storm’s aftermath.

Canopy level trees are more likely to be damaged from hurricane-associated wind and lightning strikes, while seedlings that occupy the understory are often sheltered from most of this damage, although can be damaged by falling canopy debris (Platt et al. 2000; Platt et al. 2002; Gilliam et al. 200; Zhang et al. 2008). For trees in the understory the 
physical environment can shift dramatically following a hurricane with increases in incoming solar radiation (Carlton and Bazzaz 1998; Battaglia et al. 2002, Fernandez and Fetcher 1991), temporary loss of herbivore pressure (Koptur et al. 2002), and a pulse of available soil nutrients associated with canopy-level defoliation (Lodge et al. 1991; Harmon et al. 1995; Ostertag et al. 2003; Xu et al. 2004).

Increases in available light and soil nutrients in the forest understory can benefit the growth of canopy species seedlings. Increases in nutrient and light levels have been shown to increase growth rates and biomass accumulation (Grubb et al. 1996; Denslow et al. 1998; Rodriguez-Garcia and Bravo 2013). Sudden changes in available light can cause both short- and long-term responses in photosynthesis rates and aboveground biomass allocation in seedlings (Grubb et al. 1996; Cai et al. 2008). Differences in adaptive traits between species can affect the ability of species to take advantage of dynamic environmental changes via changes in photosynthesis, growth, and biomass allocation (Fetcher et al. 1983; Fetcher et al. 1985; Monnier et al. 2013). Disturbance-adapted species often exhibit a larger amount of plasticity that allows them to reallocate biomass towards the limiting resources that promote success in changing environmental conditions (Schumacher et al 2009). In contrast, shade-adapted species may exhibit reductions in photosynthesis and growth in response to sudden increases in light levels (Fetcher et al. 1983; Oberbauer and Strain 1986).

Changes in light and soil nutrient conditions often affect the uptake and pools of nutrients within plants (Dawson et al. 2002). Increased availability of nitrogen and phosphorus can result in increased growth rates, depending on the limiting nutrient. 
Tissue nutrient concentrations are affected by a number of physiological and environmental factors (Evans 2001, Dawson et al. 2002; Funk et al 2007). Changes in $\delta^{13} \mathrm{C}$ values are also directly negatively correlated with nitrogen availability (Guehl et al. 1995; Livingston et al. 1999) and water stress causing shifts in water use efficiency (Warren et al. 2001; Dawson et al. 2002).

Tropical hardwood hammocks, cypress domes, pine rocklands, and tree islands are dominant forest types in the inland Florida Everglades. Seedlings of the most prevalent canopy trees within these four communities are the focus of this study. Cypress domes are long-hydroperiod, freshwater forests dominated by a deciduous conifer, Taxodium distichum var. nutans (bald cypress) (Gunderson 1994). Pine rockland communities are fire-adapted, dry forests dominated by an evergreen confier, Pinus elliotti var. densa (South Florida slash pine) (Gunderson 1994). Tree islands are forests within in the marsh matrix of the Everglades that are situated at higher elevations, causing them to be drier than the surrounding landscape (Gunderson 1994). Like tree islands, hardwood hammocks are forests in areas of higher elevation and are characterized by dense growth of temperate and tropical species (Gunderson 1994). Bursera simaruba (gumbo limbo), a tropical, broad-leaf species, and Quercus virginiana (southern live oak), a temperate, semi-deciduous, broad-leaf species, are both common canopy tree species in hardwood hammocks and tree islands.

In this study, I investigated the responses of the seedlings of these four canopy tree species to experimentally varied light and soil nutrient levels. In addition, I tested how each species responded to sudden light and nutrient increases as a simulation of 
hurricane-induced canopy defoliation and the subsequent nutrient pulse. My specific research questions were: How responsive are these species from different communities to light and nutrient availability? How do these varying conditions alter seedling carbon and nitrogen assimilation? How do seedling growth rates and biomass allocation change in response to sudden environmental shifts from pre-hurricane to post-hurricane environmental conditions? I predicted that the different levels of light and nutrient resources would affect growth rates and biomass allocation for each of the species differently as a result of specific life history traits. Specifically, shade-intolerant species, such as P. elliottii, would have lower growth rates in low light conditions while shadetolerant species, such as Q. virginiana, would have higher growth rates. Hurricane simulation treatment was expected to have an adverse effect on individuals shortly after treatment, but overall seedlings would respond favorably to post-hurricane conditions with increased growth rates. I expected the largest increases in growth rate post-hurricane simulation to be species that are disturbance tolerant, such as B. simaruba.

\section{V.3: Methods}

\section{V.3.1 Experimental Design}

The two experiments were conducted at the Shadehouse Facility on the campus of Florida International University, Miami, Florida. We planted seeds or collected seedlings of each species from around south Florida and grew them in uniform light and soil conditions to approximately 1-3 months of age. Seedlings were randomly assigned to treatment groups and planted individually in a $5 \mathrm{~L}, 12 \mathrm{~cm} \times 30.5 \mathrm{~cm}$ tree pot containing a 40:40:20 mix of commercial potting soil/peat moss/sand. 
The first experiment used a two-way factorial design consisting of two light and nutrient levels (Figure V.1). The four standard treatments consisted of low nutrient/low light (LNLL), low nutrient/high light (LNHL), high nutrient/low light (HNLL), and high nutrient/high light (HNHL) treatments ( $\mathrm{n}=30$ per species). Fertilization rates were $1.5 \mathrm{~g}$ Phosphorus and 3g Nitrogen/liter water for high nutrient treatments and distilled water for low nutrient treatments; nutrient levels were determined using a combination of field data and values from previous studies (Rybczyk et al. 1995; Wang et al. 2013). Fertilization of seedlings in the high nutrient treatment group was administered every two weeks. Light treatments were either full sun (high light) or reduced incoming solar radiation using 50\% shadecloth (low light). The experiment was conducted over a period of 4 months (June-August 2014).

In a second experiment, changes in light and nutrients simulating hurricane effects were used to test the plasticity response of seedlings (60 per species) in simulated intact pre-hurricane forest canopy (LNLL). After two months of pre-hurricane simulation treatment, 30 individuals of each species were harvested for above- and below-ground biomass, nutrient content, and total leaf area. The remaining 30 plants of each species were subjected to a post-hurricane simulation treatment by placement in high-light, highnutrient conditions to simulate an open, post-hurricane canopy and the storm-associated litter-fall nutrient pulse. Nutrients were added as in the HNHL treatment outlined above.

Throughout both experiments, weekly growth measurements of seedling height were taken on each individual. At the conclusion of the studies, all individuals were harvested and measured for leaf, stem, root biomass, and total leaf area. Biomass was 
dried at $60^{\circ} \mathrm{C}$ for 48 hours. Leaf tissue of five individuals from each treatment was analyzed for nutrient content (percent nitrogen) and $\delta^{13} \mathrm{C}$ isotopic content using a Thermo Scientific Finnigan Delta-C Elemental Analyzer-Infrared Mass Spectrometer (Thermo Fisher Scientific, Waltham, Massachusetts, USA) at the Florida International University Stable Isotope Lab. Photosynthesis rates were monitored weekly using a Li-6400XT photosynthesis system (LI-COR Inc., Lincoln, Nebraska, USA) on a subset of 10 randomly selected individuals from each treatment.

\section{V.3.2 Data Analysis}

Seedlings within each treatment were moved every 2 weeks in groupings of 5 pots during the study in a randomized fashion and compared at the conclusion of the study to confirm that there was no effect of pot placement within the setup before further treatment by statistical analysis. Growth rates were compared using analysis of covariance (ANOVA) with Tukey's post-hoc analysis for the factorial and hurricanesimulation treatments. Comparisons of photosynthesis rates, biomass accumulation, and nutrient content were conducted using two-way ANOVAs with a Tukey’s post-hoc analysis. Two-way analysis of variance was used for analysis despite lack of replication in light treatment. All statistical tests were conducted using the R statistical environment (R Foundation for Statistical Computing, Vienna, Austria).

\section{V.4: Results}

\section{V.4.1 Height Growth}

Height growth rates responded strongly to treatment and were species specific (Figure V.2). Plants responded to the increase in nutrients more than increases in light levels. Pinus elliottii and B. simaruba height growth rates were at their highest levels in 
HNHL conditions $\left(0.47\right.$ and $\left.4.95 \mathrm{~cm}^{\text {week }}{ }^{-1}\right)$. Pinus elliottii height growth rates were lowest in LNLL $(0.11 \mathrm{~cm} /$ week $)$ treatments and $B$. simaruba rates were lowest in LNHL $\left(0.45 \mathrm{~cm}\right.$ week $\left.^{-1}\right)$. Taxodium distichum and $Q$. virginiana height growth rates were highest in HNLL conditions (3.57 and 3.05 $\mathrm{cm}^{\text {week }}{ }^{-1}$ ). Both T. distichum and Q. virginiana had the lowest growth rates in LNHL (1.48 and $\left.0.20 \mathrm{~cm}^{\text {week }}{ }^{-1}\right)$. Across all treatments, $P$. elliottii height growth rates were lowest of all the species in the study $\left(0.11 \mathrm{~cm}^{\text {week}}{ }^{-}\right.$ ${ }^{1} \mathrm{LNLL}$ to $0.47 \mathrm{~cm}$ week $\left.{ }^{-1} \mathrm{HNHL}\right)$. Bursera simaruba had the highest growth rate of all study species (4.95cm week ${ }^{-1}$ HNHL); however, across all treatment types, T. distichum had the highest average growth rate $\left(1.48 \mathrm{~cm}^{\text {week }}{ }^{-1} \mathrm{LNHL}\right.$ to $\left.3.57 \mathrm{~cm}^{\text {week }}{ }^{-1} \mathrm{HNLL}\right)$. Relative growth rates (RGR) in height were larger in the two broad-leaf species compared to the conifers (Table V.1). The highest RGR were consistently in the HNLL conditions for all species, except $T$. distichum, which grew equally well in HNHL and HNLL (+7.0 and $+7.1 \%$ week $^{-1}$ respectively).

Growth rates from the pre- and post-hurricane simulation treatment were species specific, although only broad-leaf species showed significant increases in rate of height growth (Figure V.3). Bursera simaruba showed the largest increase in growth posthurricane simulation treatment $\left(+2.01 \mathrm{~cm} \mathrm{week}^{-1}, \mathrm{p}<0.001\right)$ and $Q$. virginiana growth rates showed moderate increases $\left(+0.60 \mathrm{~cm}^{\text {week }}{ }^{-1}, \mathrm{p}=0.028\right)$. For the conifer species $P$. elliottii and $T$. distichum, growth rates did not significantly change after the posthurricane simulation treatment $\left(+0.12 \mathrm{~cm}^{\text {week }}{ }^{-1}, \mathrm{p}=0.791\right.$ and $+0.40 \mathrm{~cm}_{\text {week }}{ }^{-1}, \mathrm{p}=0.361$ respectively). Relative growth rates only increased in post-hurricane simulation treatment in the broad-leaf species, Q. virginiana and B. simaruba, compared with the LNLL treatment (Table V.2, 3.9-9.4\% week ${ }^{-1}$, $\mathrm{p}=0.002$ and 5.7-17.2\% 
week $^{-1}, \mathrm{p}<0.001$ respectively).

\section{V.4.2 Biomass Accumulation}

Total dry biomass accumulation varied among species and treatment with $P$. elliottii and B. simaruba accumulating the largest overall biomass (2.3-7.9g and 0.213.0g, respectively, Table V.1, Figure V.6). Total biomass was highest for T. distichum, P. elliottii, and B. simaruba in HNHL treatments (3.9, 7.9, and 13.0g); however, biomass was highest for Q. virginiana in the HNLL treatment (3.3g). Across all species, total biomass accumulation was higher in HN compared to LN treatments. Root, shoot and leaf biomass allocation percentages were similar across all treatment types for $T$. distichum and B. simaruba, however P. elliottii and Q. virginiana showed shifts towards greater root allocation when grown in LN conditions. Total leaf area and root:shoot ratios were species and treatment specific. Total leaf area was largest for all species in HN conditions. T. distichum and Q. virginiana total leaf area was largest under HNLL conditions (63.8 and $66.1 \mathrm{~cm}^{2}$ ) while $P$. elliottii and $B$. simaruba were largest under HNHL conditions (76.2 and 398.6 $\mathrm{cm}^{2}$ ). All species had the highest specific leaf area (SLA) in LNHL treatments, except T. distichum in which SLA was highest in LNLL. Root:shoot ratios were highest for P. elliottii and B. simaruba in LNHL treatments (1.40 and 0.40) and for Q. virginiana in LNLL (1.10) and T. distichum in HNLL (0.82). Across all treatments, $Q$. virginiana had the highest root:shoot ratio (1.00 to 1.80$)$ and $B$. simaruba had the lowest (0.30 to 0.40$)$.

Taxodium distichum, $P$. elliottii, and B. simaruba increased in overall biomass accumulation between LNLL and post-hurricane simulation treatment $(+1.4 \mathrm{~g}, \mathrm{p}=0.002$, +4.8g $\mathrm{p}<0.001$, and $+0.7 \mathrm{~g} \mathrm{p}=0.041$, respectively, Table V.2), however $Q$. virginiana did 
not. Biomass allocation was consistent between LNLL and post-hurricane simulation treatment, however Q. virginiana did show a slight decrease in root allocation (-3.4\%) to leaf (+4.6\%). Total leaf area also increased between LNLL and post-hurricane simulation treatment in $P$. elliottii and B. simaruba $\left(+48.0\right.$ and $+21.4 \mathrm{~cm}^{2}$, both $\left.\mathrm{p}<0.001\right)$. Taxodium distichum was the only species that significantly decreased specific leaf area (SLA) after hurricane simulation treatment $\left(-58.7 \mathrm{~cm}^{2}\right.$ $\left.\mathrm{g}^{-1}, \mathrm{p}<0.001\right)$, while $P$. elliottii was the only species that increased $\left(+9.8 \mathrm{~cm}^{2} \mathrm{~g}^{-1}\right.$, $\mathrm{p}=0.014)$. Quercus virginiana and $P$. elliottii were the only species that significantly altered root:shoot ratio post-hurricane simulation treatment $(-0.2, p=0.037$ and +0.3 , $\mathrm{p}=0.029$, respectively).

\section{V.4.3 Photosynthesis Estimates}

Trends in photosynthetic rates across all treatment types were similar to those described for weekly height growth rates for all species, with increased nutrient availability having the greatest effect (Figure V.4). Taxodium distichum and Q.

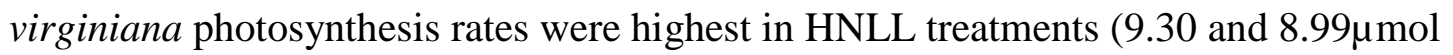
$\mathrm{CO}_{2} / \mathrm{m}^{2} / \mathrm{s}$ ) while rates of $P$. elliottii and $B$. simaruba were highest in HNHL treatments (7.60 and $10.96 \mu \mathrm{mol} \mathrm{CO}_{2} / \mathrm{m}^{2} / \mathrm{s}$ ). For $T$. distichum and P. elliottii photosynthesis rates, there were no statistically significant differences among any treatments $(p=0.420$ and $\mathrm{p}=0.267$, respectively). Differences between LNLL and post-hurricane simulation treatments also were not significantly different for any species, with only $B$. simaruba displaying a noticeable increase post-hurricane treatment (7.64 to $9.02 \mu \mathrm{mol} \mathrm{CO}_{2} / \mathrm{m}^{2} / \mathrm{s}$, $\mathrm{p}=0.042$, Figure V.5)). 


\section{V.4.4 Tissue N, C Content, and Isotope Values}

Reponses of leaf percent nitrogen content to varying light and nutrient availability segregated by species (Table V.3). The two broad leaf species, Q. virginiana and B. simaruba had the highest leaf nitrogen content in HNLL conditions (1.78\% and 2.50\% respectively), however the conifer species, $T$. distichum $(\mathrm{HNHL}=1.86 \%)$ and $P$. elliottii (LNHL=0.79\%), had highest values in high light conditions. Leaf percent nitrogen content was lowest for all species in LNLL conditions. P. elliottii had the lowest overall leaf nitrogen content (0.65\% to $0.79 \%)$ and $B$. simaruba had the highest overall nitrogen content $(1.90 \%$ to $2.50 \%)$. Isotopic $\delta^{13} \mathrm{C}$ content values were mixed across all treatment types and species with no clear trends.

Leaf nitrogen content after the post-hurricane simulation was higher than LNLL treatment in T. distichum and B. simaruba $(+0.58 \%, \mathrm{p}=0.034$ and $+1.03 \%, \mathrm{p}=0.004$, respectively, Table V.4). All species had significant changes in $\delta^{13} \mathrm{C}$ values post hurricane simulation treatment, although the magnitude and direction of these changes were species specific. In the post hurricane simulation treatment, $T$. distichum and $B$. simaruba became more enriched in $\delta^{13} \mathrm{C}(+0.92 \%$, $\mathrm{p}=0.012$ and $+1.14 \%$, $\mathrm{p}=0.006$, respectively), while $Q$. virginiana and $P$. elliottii became more depleted (-0.54\%o, $\mathrm{p}=0.023$ and $-0.47 \%$, $\mathrm{p}=0.028$, respectively).

\section{V.5: Discussion}

As predicted, varying levels of available light and soil nutrients affect the photosynthetic rates, growth and ultimately biomass accumulation of the four study 
species. Higher soil nutrient levels had a larger effect on growth and biomass accumulation compared to the effects of light levels, a finding consistent with previous studies (Denslow et al. 1998; Rodriguez-Garcia and Bravo 2013). This may be a consequence of light levels only being reduced to $50 \%$ in the low light treatments. Despite the apparent trend of higher soil nutrient availability having the largest effect on growth rates, differences in the optimal conditions are likely results of the various life history traits of the four study species. For example, the shade tolerant species, $Q$. virginiana, displayed highest relative height growth rates in conditions with adequate soil nutrients and low light conditions (HNLL). Pinus elliottii also had the highest relative height growth rates in HNLL conditions, despite being shade intolerant, which was contrary to what was expected.

Both conifer species (T. distichum and $P$. elliottii) showed no overall change in photosynthetic rates in any treatment type. This could be a result of a physiologic tolerance of lower resource levels needed for to sustain levels of growth. Our results are consistent with the literature showing that increased light availability did not have an effect on conifer growth (Carswell et al. 2012). The two broad-leaf species (Q. virginiana and B. simaruba) had the highest photosynthetic rates in nutrient rich conditions (HNHL and HNLL) suggesting that these two species were nutrient limited in treatments with low soil nutrient availability. The two broad-leaf species, however, differed in the light conditions in which they grew optimally. The fast growing, disturbance adapted $B$. simaruba had the highest photosynthetic rates under high light conditions while the slower growing, late-successional species $Q$. virginiana was under low light conditions. 
This difference between the two broad-leaf species is likely a result of adaptations to seedlings germinating in a more open canopy (B. simaruba) or a more closed one $(Q$. virginiana). Both B. simaruba and Q. virginiana had the lowest growth rates in conditions of LNHL, suggesting nutrient availability plays a vital role in how these two species compensate for higher levels of incoming solar radiation and water loss.

Growth rates of $Q$. virginiana and $B$. simaruba increased as they moved from prehurricane simulation low light/low nutrient conditions to post-hurricane high light/high nutrient conditions, with the largest increase in B. simaruba. This finding suggests that faster growing species, such as $B$. simaruba, may be able to more effectively take advantage of shifts in their immediate physical environment compared to more slow growing, late successional species, such as $Q$. virginiana. T. distichum and P. elliottii showed little change in growth rate with simulated post-hurricane light and nutrient increases. In T. distichum this finding may result from most individuals losing a portion their leaves when moved from low light to high light conditions.

Total biomass accumulation and biomass tissue allocation were also affected by resource availability and individual species traits. Total biomass accumulation of all the species increased with higher nutrient and light levels; however the availability of soil nutrient pools appears to play a larger role. The response of all species to low light availability compared to high light availability was allocation to increased leaf biomass but not an increase in leaf area; these results are contrary to previous studies in which lower light levels cause higher leaf area (Grubb et al. 1996; Cai et al. 2008). Despite increases in total biomass accumulation with increased resource availability, T. distichum 
and B. simaruba showed little difference in biomass allocation among tissues. Pinus elliotti and Q. virginiana accumulated the least amount of total biomass; however, they showed the largest variation in biomass allocation. Pinus elliotti shifted allocation most noticeably from leaves to roots under LNHL conditions, while $Q$. virginiana shifted allocation from roots to leaves in LNLL conditions. Shifts in these two slow growing species suggest a plasticity of biomass allocation, allowing them to survive under stressful conditions consistent with growing under canopies and foraging for the most limiting nutrient in their immediate environment.

Biomass allocation in response to the simulated hurricane treatment showed that all of the four species increased in size, but only $Q$. virginiana showed a reallocation of biomass from root tissue to leaves. This ability to reallocate resources as environmental conditions change is beneficial in a species that is slow-growing and may be impacted by multiple hurricanes throughout it life. All of the species except $T$. distichum showed an increase in leaf area after simulated hurricane treatment. Loss of leaf area in T. distichum was likely due to dropping leaves at the transition from pre- to post-hurricane simulation, and it was not able to recover its leaf area over the remainder of the study.

Simulated post-hurricane conditions and the responses of species to those conditions demonstrate the ability of understory seedlings to regenerate the canopy following a storm. T. distichum suffered varying degrees of leaf loss when environmental conditions abruptly changed and did not alter its growth rates in response to newly available resources. However, this may not affect $T$. distichum's ability to regenerate the canopy of cypress domes because the long hydroperiods associated with these habitats 
suppress the recruitment of other species. $P$. elliottii had the slowest height growth of all the study species; however, after hurricane simulation treatment, it had an increase in leaf area, height growth rate and, ultimately, total biomass, suggesting an ability to take advantage of changes in resource availability. B. simaruba was the fastest growing of all the species in optimal conditions and was quickly able to take advantage of the new conditions (post-hurricane) by increasing its growth rates and leaf area. Q virginiana showed only a slight increase in growth rate and biomass accumulation in the posthurricane simulation this species; however, showed the largest degree of biomass plasticity in allocation allowing it to adjust for changing conditions.

For each species, treatments with the highest growth rates were consistently different from treatments with the highest nitrogen content, with the exception of $Q$. virginiana. This finding is consistent with those of previous studies in which leaf nitrogen content and growth was not correlated (Funk et al 2007). Faster growing species may dilute nitrogen content in the plant as biomass is accumulated compared with slower growing species. Nitrogen availability may have been above the limiting resource threshold and therefore was not correlated with changes in growth rate.

Carbon isotopic $\left(\delta^{13} \mathrm{C}\right)$ enrichment was highest in low light treatments, except $T$. distichum, suggesting that water stress was not a major factor for most of the plants in the study (Warren et al 2001). $\delta^{13} \mathrm{C}$ was enriched when faster growing individuals ( $T$. distichum and B. simaruba) were transferred from pre- to post-hurricane simulation conditions, which may have resulted from higher photosynthesis rates. This was not the case in individuals of slower growing species ( $Q$. virginiana and $P$. elliottii), which 
became more depleted in $\delta^{13} \mathrm{C}$ post hurricane simulation. This result may be explained by more conservative growth rates being associated with higher water use efficiency. Increases in incoming solar radiation in the post hurricane simulation may play a role in the stomatal conductance through increasing transpiration rates and resulting water use efficiency of these faster growing species (T. distichum and B. simaruba), resulting in $\delta^{13} \mathrm{C}$ enrichment (Dawson et al 2002, Guehl et al 2003).

Overall, each of the study species responded to varying resource availability in different ways that demonstrate differences in adaptive traits. Seedlings of $Q$. virginiana and P. elliottii are slow growing species that allocate caloric surplus into storage rather than growth. The P. elliottii in this size class are in the "grass" stage, when they store large amounts of photosynthate but have low height growth to keep the meristem low to the ground to survive frequent fires (Lohrey et al 1990). This study reinforces findings as the slower growing species were less likely to alter growth rates and instead shift biomass allocations. Alternatively, the faster growing study species, T. distichum and B. simaruba, demonstrated less change in biomass allocations and increased their growth rates in more favorable conditions. Species specific traits and resulting resource utilization habits have the potential to alter competiveness in response to changing conditions.

In conclusion, nutrient levels had a larger impact than light levels on growth rates and biomass accumulation in this study. The magnitudes of treatment impacts varied considerably and were often species specific. Faster growing species were able to more readily take advantage of favorable conditions through increased growth rates and biomass accumulation, while slower growing species shifted tissue biomass allocation to 
cope with varying conditions. Broad-leaf species were able to compensate for sudden changes in light and nutrient availability associated with a simulated hurricane treatment through increased growth rates and biomass accumulation, while coniferous species did not. Responses of these target species to shifts in available light and nutrient shifts may shed light on how other species in the system with similar characteristics may also respond. Variations in species-specific responses to different environmental conditions may explain how hurricane disturbances can alter the trajectories of community succession in the Everglades and other systems.

\section{V.6: References}

Battaglia, L. L., S. A. Fore, R. R. Sharitz. (2001). "Seedling emergence, survival and size in relation to light and water availability in two bottomland hardwood species." Journal of Ecology. 88(6):1041-1050.

Boose, E. R., D. R. Foster, M. Fluet. (1994). "Hurricane impacts to tropical and temperate forest landscapes.” Ecological Monographs. 64: 369-400.

Cai, Z-Q., L. Poorter, Q. Han, F. Bongers. (2008). "Effects of light and nutrients on seedlings of tropical Bauhinia lianas and trees.” Tree Physiology 28:1277-1285.

Carlton, G. C. and F. A. Bazzaz. (1998). "Resource congruence and forest regeneration following an experimental hurricane blowdown.” Ecology 79:1305-1319.

Carswell, F. E., J. E Doherty, R. B. Allen, M. E. Brignall-Theyer, S. J. Richardson, S. K.Wiser. (2012). "Quantification of the effects of aboveground and belowground competition on growth of seedling in a conifer-angiosperm forest.” Forest Ecology and Management. 269:188-196.

Dawson, T. E., S. Mambelli, A. H. Plamboeck, P. H. Templer, K. P. Tu. 2002. "Stable isotopes in plant ecology." Annual Review of Ecological Systems. 33:507-559.

Denslow J. S., A. M. Ellison, R. E. Sanford. (1998). “Treefall gap size effects on aboveand below-ground processes in a tropical wet forest.” Journal of Ecology 86(4): 597-609. 
Evans, R. D. 2001. "Physiological mechanisms influencing plant nitrogen isotope composition." TRENDS in Plant Science. 6(3):121-126.

Everham, E. M. and N. V. L. Brokaw. (1996) "Forest damage and recovery from catastrophic wind.” Botanical Review. 62(2): 113-185.

Fernandez, D.S. and N. Fetcher. (1991). "Changes in Light Availability Following Hurricane Hugo in a Subtropical Montane Forest in Puerto Rico.” Biotropica 23(4a): 393-399.

Fetcher, N., Strain, B. R., \& Oberbauer, S. F. (1983). "Effects of light regime on the growth, leaf morphology, and water relations of seedlings of two species of tropical trees.” Oecologia, 58(3): 314-319.

Fetcher, N., Oberbauer, S. F., \& Strain, B. R. (1985). "Vegetation effects on microclimate in lowland tropical forest in Costa Rica." International Journal of Biometeorology, 29(2): 145-155.

Funk, J. L., C. G. Jones, M. T. Lerdau. 2007. "Leaf- and shoot-level plasticity in response to different nutrient and water availbilities." Tree Physiology. 27:1731-1739.

Gilliam, F. S., W. J. Platt, R. K. Peet. (2006). "Natural disturbances and the physiognomy of pine savannas: A phenomenological model." Applied Vegetation Science 9(1): 83-96.

Grubb, P. J., W. G. Lee, J. Kollman, J. B. Wilson. (1996). “Interaction of irradiance and soil nutrient supply on growth of seedlings of ten European tall-shrub species and Fagus sylvatica.” Journal of Ecology. 84:827-840.

Guehl, J-M., C. Fort, A. Ferhi. 1995. "Differential response of leaf conductance, carbon isotope discrimination and water-use efficiency to nitrogen deficiency in maritime pine and pedunculate oak plants." New Phytologist. 131:149-157.

Gunderson, L. H. (1994). "Vegetation of the Everglades: Determinants of Community Composition.” Everglades:The Ecosystem and Its Restoration. S. M. Davis and J. C. Ogden eds. CRC Press.

Gunderson, L. H. (2000). “Ecological Resilience: In Theory and Application.” Annual Review of Ecology and Systematics 31: 425-439.

Harmon, M. E., D. F. Whigham, J. Sexton, I. Olmsted. (1995). "Decomposition and mass of woody detritus in the tropical dry forests of the northeastern Yucatan Peninsula, Mexico.” Biotropica. 27(3):305-316.

Koptur, S., M. C. Rodriguez, S. F. Oberbauer, C. Weekley, A. Herndon. (2002). "Herbivore-free time? Damage to new leaves of woody plants after Hurricane Andrew." 
Biotropica 34(4): 547-554.

Livingston, N. J., R. D. Guy, Z. J. Sun, G. J. Ethier. 1999. "The effects of nitrogen stress on the stable carbon isotope composition, productivity and water use efficiency of white spruce (Picea glauca(Moench) Voss) seedlings." Plant, Cell and Environment. 22: 281289.

Lodge, D. J., F. N. Scatena, C. E. Asbury, M. J. Sanchez. (1991). “Fine Litterfall and Related Nutrient Inputs Resulting from Hurricane Hugo in Subtropical Wet and Lower Montane Rain Forests in Puerto Rico.” Biotropica. 23(4a):336-342.

Lohrey, R.E., S. V. Kossuth. 1990. "Pinus elliottii Engelm.” Silvics of North America. Washington; USDA, Forest Service. 1:338-47.

Monnier, Y., A. Bousquet-Melou, B. Vila, B. Prévosto, C. Fernandez. (2013) “How nutrient availability influences acclimation to shade of two (pioneer and latesuccessional) Mediterranean tree species?” European Journal of Forest Restoration. 132:325-333.

Oberbauer, S. F., \& Strain, B. R. (1986). "Effects of canopy position and irradiance on the leaf physiology and morphology of Pentaclethra macroloba (Mimosaceae)." American Journal of Botany.409-416.

Ostertag, R., F. N. Scatena, W. L. Silver. (2003). "Forest floor decomposition following hurricane litter inputs in several Puerto Rican forests.” Ecosystems. 6(3):261-273.

Platt, W. J., B. Beckage, R. F. Doren, H. H. Slater. (2002). "Interactions of large-scale disturbances: Prior fire regimes and hurricane mortality of savanna pines." Ecology 83(6): 1566-1572.

Platt, W. J., R. F. Doren, T. V. Armentano. (2000). "Effects of Hurricane Andrew on stands of slash pine (Pinus elliottii var. densa) in the everglades region of south Florida (USA)." Plant Ecology 146(1): 43-60.

Rodriguez-Garcia, E., and F. Bravo. (2013). "Plasticity in Pinus pinaster populations of diverse origins: Comparative seedling responses to light and Nitrogen availability." Forest Ecology and Management. 307:196-205.

Rybczyk, J. M., X. W. Zhang, J. W. Day Jr, I. Hesse, S. Feagley. (1995). "The impact of Hurricane Andrew on tree mortality, litterfall, nutrient influx, and water quality in a Louisiana coastal swamp forest.” Journal of Coastal Research S1(21):340-353.

Schumacher, E., C. Kueffer, P. J. Edwards, H. Dietz. (2009) "Influence of light and nutrient conditions on seedling growth of native and invasive trees in the Seychelles." 
Biological Invasions. 11:1941-1954.

Stanturf, J. A., S. L. Goodrick, K. W. Outcalt. (2007). "Disturbance and coastal forests: A strategic approach to forest management in hurricane impact zones." Forest Ecology and Management. 250(1-2):119-135.

Wang, F., J. Liu, B. Zou, D. A. Neher, W. Zhu, Z. Li. (2013) “Species-dependent responses of soil microbial properties to fresh litter inputs in a subtropical forest soil in South China.” Journal of Plant Ecology. 8(5).

Warren, C. R., J. F. McGrath, M. A. Adams. 2001. "Water availability and carbon isotope discrimination in conifers.” Oecologia. 127:476-486.

Whelan, K R T. 1997 "Short Term Response of Two Cypress Communities Within Everglades National Park To The Effects of Hurricane Andrew”. Masters Thesis. Florida International University.

Xu, X. N., E. Hirata, H.. Shibata. (2004). "Effect of typhoon disturbance on fine litterfall and related nutrient input in a subtropical forest on Okinawa Island., Japan.” Basic and Applied Ecology. 5(3):271-282.

Zhang, K. Q., M. Simard, M. Ross, V. H. Rivera-Monroy, P. Houle, P. Ruiz, R. R. Twilley, K. R. T. Whelan. (2008). "Airborne laser scanning quantification of disturbances from hurricanes and lightning strikes to mangrove forests in Everglades National Park, USA." Sensors 8(4): 2262-2292.

Zimmerman, J. K., E. M. Everham III, R. B. Waide, D. J. Lodge, C. M. Taylor, N. V. Brokaw. (1994). "Responses of tree species to hurricane wind in subtropical wet forest in Puerto Rico- Implications for tropical tree life histories.” Journal of Ecology. 82(4):911-922. 
Table V.1: Total dry biomass (including root, shoot, and leaf percentages), total leaf area, relative growth rate (RGR), root:shoot ratio, and specific leaf area (SLA) for all four species across all treatment types. $(n=30$, letters indicate results from Tukey's post-hoc analysis on a two-way analysis of variance)

\begin{tabular}{|c|c|c|c|c|c|c|c|c|}
\hline & \multicolumn{2}{|c|}{ HNHL } & \multicolumn{2}{|c|}{ LNHL } & \multicolumn{2}{|c|}{ HNLL } & \multicolumn{2}{|c|}{ LNLL } \\
\hline \multicolumn{9}{|c|}{ Taxodium distichum } \\
\hline Root \% & 41.9 & a & 42.1 & $\mathrm{a}$ & 43.2 & $\mathrm{a}$ & 40.5 & $\mathrm{a}$ \\
\hline Shoot \% & 36.8 & $\mathrm{a}$ & 42.0 & $\mathrm{a}$ & 35.2 & $\mathrm{a}$ & 37.8 & $\mathrm{a}$ \\
\hline Leaf \% & 21.3 & $\mathrm{a}$ & 15.9 & $\mathrm{a}$ & 21.6 & $\mathrm{a}$ & 21.7 & $\mathrm{a}$ \\
\hline Total Biomass (g) & 3.9 & $\mathrm{a}$ & 2.1 & b & 3.2 & $\mathrm{a}$ & 1.9 & b \\
\hline Leaf Area $\left(\mathrm{cm}^{2}\right)$ & 59.4 & $\mathrm{a}$ & 29.5 & $\mathrm{~b}$ & 63.8 & $\mathrm{a}$ & 43.7 & $\mathrm{ab}$ \\
\hline RGR (\%/week) & 7.0 & $\mathrm{a}$ & 2.1 & $\mathrm{~b}$ & 7.1 & $\mathrm{a}$ & 4.2 & $\mathrm{ab}$ \\
\hline R:S Ratio & 0.65 & $\mathrm{a}$ & 0.75 & $\mathrm{a}$ & 0.82 & $a b$ & 0.70 & $b$ \\
\hline $\operatorname{SLA}\left(\mathrm{cm}^{2} / \mathrm{g}\right)$ & 71.4 & a & 89.5 & $\mathrm{~b}$ & 92.7 & $\mathrm{~b}$ & 107.4 & C \\
\hline \multicolumn{9}{|c|}{ Quercus virginiana } \\
\hline Root \% & 50.1 & a & 59.6 & $\mathrm{ab}$ & 52.5 & $\mathrm{a}$ & 64.4 & $\mathrm{~b}$ \\
\hline Shoot \% & 20.5 & $\mathrm{a}$ & 18.9 & $\mathrm{a}$ & 15.9 & $\mathrm{ab}$ & 14.2 & $\mathrm{~b}$ \\
\hline Leaf \% & 29.3 & $\mathrm{a}$ & 21.5 & b & 31.6 & $\mathrm{a}$ & 21.4 & $\mathrm{~b}$ \\
\hline Total Biomass (g) & 0.9 & $\mathrm{a}$ & 0.3 & $\mathrm{a}$ & 3.3 & $\mathrm{~b}$ & 0.5 & $\mathrm{a}$ \\
\hline Leaf Area $\left(\mathrm{cm}^{2}\right)$ & 36.0 & $\mathrm{a}$ & 14.2 & $\mathrm{~b}$ & 66.1 & c & 17.3 & $\mathrm{~b}$ \\
\hline RGR (\%/week) & 28.4 & $\mathrm{a}$ & 3.4 & b & 38.7 & c & 3.9 & $\mathrm{~b}$ \\
\hline R:S Ratio & 1.00 & $\mathrm{a}$ & 1.50 & $\mathrm{a}$ & 1.10 & $\mathrm{~b}$ & 1.80 & c \\
\hline SLA $\left(\mathrm{cm}^{2} / \mathrm{g}\right)$ & 130.7 & $\mathrm{a}$ & 208.9 & $\mathrm{~b}$ & 62.4 & c & 172.9 & $d$ \\
\hline \multicolumn{9}{|c|}{ Pinus elliottii } \\
\hline Root \% & 42.5 & $\mathrm{a}$ & 58.8 & $\mathrm{~b}$ & 41.2 & a & 42.3 & $\mathrm{a}$ \\
\hline Shoot \% & 24.4 & $\mathrm{a}$ & 23.0 & $\mathrm{a}$ & 18.0 & $\mathrm{~b}$ & 24.6 & $\mathrm{a}$ \\
\hline Leaf \% & 33.1 & $\mathrm{a}$ & 18.2 & b & 40.8 & $\mathrm{C}$ & 33.1 & $\mathrm{a}$ \\
\hline Total Biomass (g) & 7.9 & $\mathrm{a}$ & 3.0 & b & 6.1 & $a b$ & 2.3 & b \\
\hline Leaf Area $\left(\mathrm{cm}^{2}\right)$ & 76.2 & $\mathrm{a}$ & 25.7 & bc & 45.8 & $\mathrm{~b}$ & 22.5 & C \\
\hline RGR (\%/week) & 3.3 & $\mathrm{a}$ & 3.9 & $a b$ & 6.2 & $\mathrm{~b}$ & 1.4 & c \\
\hline R:S Ratio & 0.70 & $\mathrm{a}$ & 1.40 & $\mathrm{~b}$ & 0.70 & C & 0.70 & c \\
\hline SLA $\left(\mathrm{cm}^{2} / \mathrm{g}\right)$ & 29.0 & $\mathrm{a}$ & 46.4 & b & 18.5 & c & 29.2 & $\mathrm{a}$ \\
\hline
\end{tabular}


Table V.1 continued

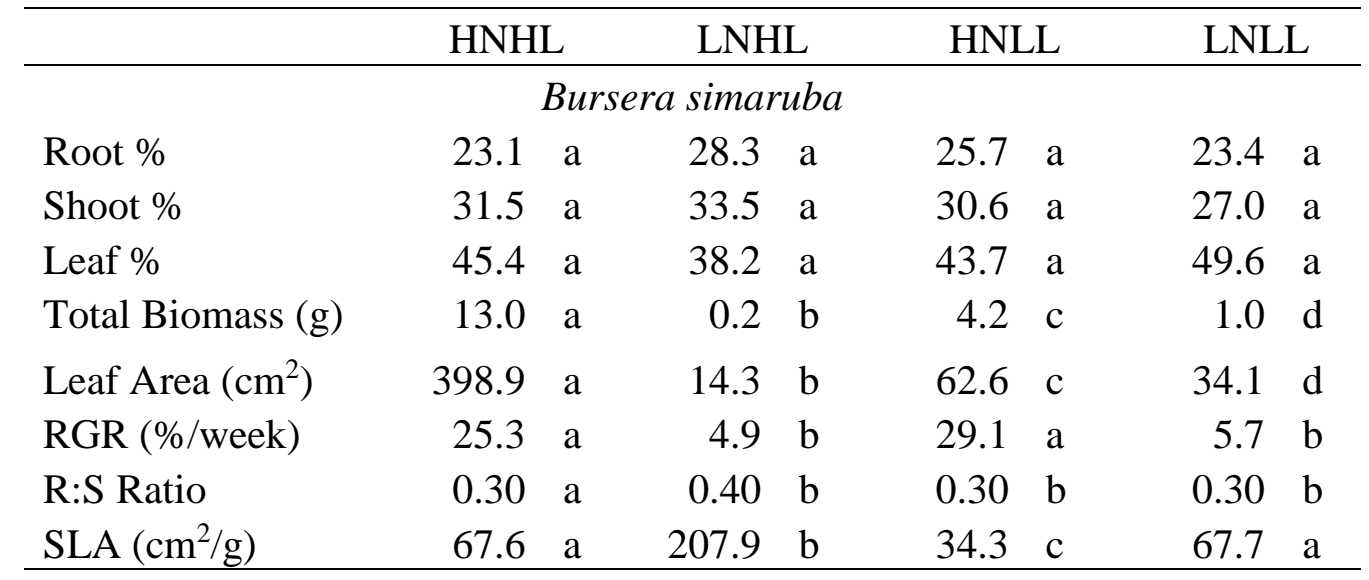


Table V.2: Total dry biomass (including root, shoot, and leaf percentages), total leaf area, relative growth rate (RGR), root:shoot ratio, and specific leaf area (SLA) for all four species for low nutrient/low light (LNLL) and post-hurricane simulation treatments. $(\mathrm{n}=30, *$ indicates $\mathrm{p}$ value $<0.05$ results $)$.

\begin{tabular}{|c|c|c|c|}
\hline & LNLL & Post & \\
\hline \multicolumn{4}{|c|}{ Taxodium distichum } \\
\hline Root \% & 40.5 & 42.5 & \\
\hline Shoot \% & 37.8 & 32.9 & \\
\hline Leaf \% & 21.7 & 24.5 & \\
\hline Total Biomass (g) & 1.9 & 3.3 & $*$ \\
\hline Leaf Area $\left(\mathrm{cm}^{2}\right)$ & 43.7 & 39.2 & \\
\hline RGR (\%/week) & 4.2 & 3.3 & \\
\hline R:S Ratio & 0.70 & 0.69 & \\
\hline $\operatorname{SLA}\left(\mathrm{cm}^{2} / \mathrm{g}\right)$ & 107.4 & 48.7 & $*$ \\
\hline \multicolumn{4}{|c|}{ Quercus virginiana } \\
\hline Root \% & 64.4 & 61.0 & \\
\hline Shoot \% & 14.2 & 13.1 & \\
\hline Leaf \% & 21.4 & 26.0 & \\
\hline Total Biomass (g) & 0.5 & 0.5 & \\
\hline Leaf Area $\left(\mathrm{cm}^{2}\right)$ & 17.3 & 20.5 & \\
\hline RGR (\%/week) & 3.9 & 9.4 & $*$ \\
\hline R:S Ratio & 1.80 & 1.60 & $*$ \\
\hline $\operatorname{SLA}\left(\mathrm{cm}^{2} / \mathrm{g}\right)$ & 172.9 & 159.6 & \\
\hline
\end{tabular}

Pinus elliottii

$\begin{array}{lrrrl}\text { Root \% } & 42.3 & 49.8 & \\ \text { Shoot \% } & 24.6 & 24.5 & \\ \text { Leaf \% } & 33.1 & 25.6 & \\ \text { Total Biomass (g) } & 2.3 & 7.1 & * \\ \text { Leaf Area }\left(\mathrm{cm}^{2}\right) & 22.5 & 70.5 & * \\ \text { RGR (\%/week) } & 1.4 & 1.9 & \\ \text { R:S Ratio } & 0.70 & 1.00 & * \\ \text { SLA }\left(\mathrm{cm}^{2} / \mathrm{g}\right) & 29.2 & 39.0 & *\end{array}$




\begin{tabular}{lcrl}
\hline \multicolumn{3}{c}{ Table V.2 continued } \\
\hline \multicolumn{4}{c}{ Bursera simaruba } \\
Root \% & 23.4 & 20.4 & \\
Shoot \% & 27.0 & 30.3 & \\
Leaf \% & 49.6 & 49.2 & \\
Total Biomass (g) & 1.0 & 1.7 & \\
Leaf Area (cm $\left.{ }^{2}\right)$ & 34.1 & $55.5 *$ \\
RGR $(\% / w e e k)$ & 5.7 & 17.2 & $*$ \\
R:S Ratio & 0.30 & 0.30 & \\
SLA $\left(\mathrm{cm}^{2} / \mathrm{g}\right)$ & 67.7 & 66.7 & \\
\hline
\end{tabular}


Table V.3: Leaf percent nitrogen and $\delta^{13} \mathrm{C}$ isotopic content for all species across all treatment types. ( $\mathrm{n}=5$ letters indicate results from Tukey's post-hoc analysis on a twoway analysis of variance).

\begin{tabular}{|c|c|c|c|c|c|c|c|}
\hline & \multicolumn{2}{|c|}{ HNHL } & LNHL & \multicolumn{2}{|c|}{ HNLL } & \multicolumn{2}{|c|}{ LNLL } \\
\hline \multicolumn{8}{|c|}{ Taxodium distichum } \\
\hline$\% \mathrm{~N}$ & 1.86 & a & 1.72 a & 1.79 & $\mathrm{a}$ & 1.62 & $\mathrm{ab}$ \\
\hline$\delta^{13} \mathrm{C}$ & -29.21 & a & $-28.96 \mathrm{~b}$ & -29.35 & ac & -29.69 & C \\
\hline \multicolumn{8}{|c|}{ Quercus virginiana } \\
\hline$\% \mathrm{~N}$ & 1.22 & ac & 1.22 ac & 1.78 & $\mathrm{~b}$ & 1.14 & ac \\
\hline$\delta^{13} \mathrm{C}$ & -31.10 & $\mathrm{ab}$ & $-31.28 \mathrm{a}$ & -30.36 & c & -30.32 & C \\
\hline \multicolumn{8}{|c|}{ Pinus elliottii } \\
\hline$\% \mathrm{~N}$ & 0.73 & a & $0.79 \quad \mathrm{a}$ & 0.78 & $\mathrm{a}$ & 0.65 & a \\
\hline$\delta^{13} \mathrm{C}$ & -31.03 & a & $-31.48 b$ & -31.57 & $a b$ & -30.61 & C \\
\hline \multicolumn{8}{|c|}{ Bursera simaruba } \\
\hline$\% \mathrm{~N}$ & 2.28 & $\mathrm{ab}$ & 2.08 a & 2.50 & $\mathrm{~b}$ & 1.90 & c \\
\hline$\delta^{13} \mathrm{C}$ & -30.95 & $\mathrm{a}$ & -31.57 & -30.69 & ac & -31.27 & $\mathrm{ab}$ \\
\hline
\end{tabular}


Table V.4: Leaf nitrogen percent and $\delta^{13} \mathrm{C}$ isotopic content for all species for low nutrient/low light (LNLL) and post-hurricane simulation treatments. ( $\mathrm{n}=5$ letters indicate results from Tukey's post-hoc analysis on a two-way analysis of variance).

\begin{tabular}{|c|c|c|c|}
\hline & LNLL & $\begin{array}{c}\text { Post- } \\
\text { Hurricane } \\
\text { Simulatior }\end{array}$ & \\
\hline \multicolumn{4}{|c|}{ Taxodium distichum } \\
\hline$\% \mathrm{~N}$ & 1.62 & 2.24 & * \\
\hline$\delta^{13} \mathrm{C}$ & -29.69 & -28.77 & $*$ \\
\hline \multicolumn{4}{|c|}{ Quercus virginiana } \\
\hline$\% \mathrm{~N}$ & 1.14 & 1.25 & \\
\hline$\delta^{13} \mathrm{C}$ & -30.32 & $-30.86 *$ & $*$ \\
\hline \multicolumn{4}{|c|}{ Pinus elliottii } \\
\hline$\% \mathrm{~N}$ & 0.65 & 0.85 & \\
\hline$\delta^{13} \mathrm{C}$ & -30.61 & -31.08 & * \\
\hline \multicolumn{4}{|c|}{ Bursera simaruba } \\
\hline$\% \mathrm{~N}$ & 1.90 & 2.93 & $*$ \\
\hline$\delta^{13} \mathrm{C}$ & -31.27 & -30.13 & * \\
\hline
\end{tabular}




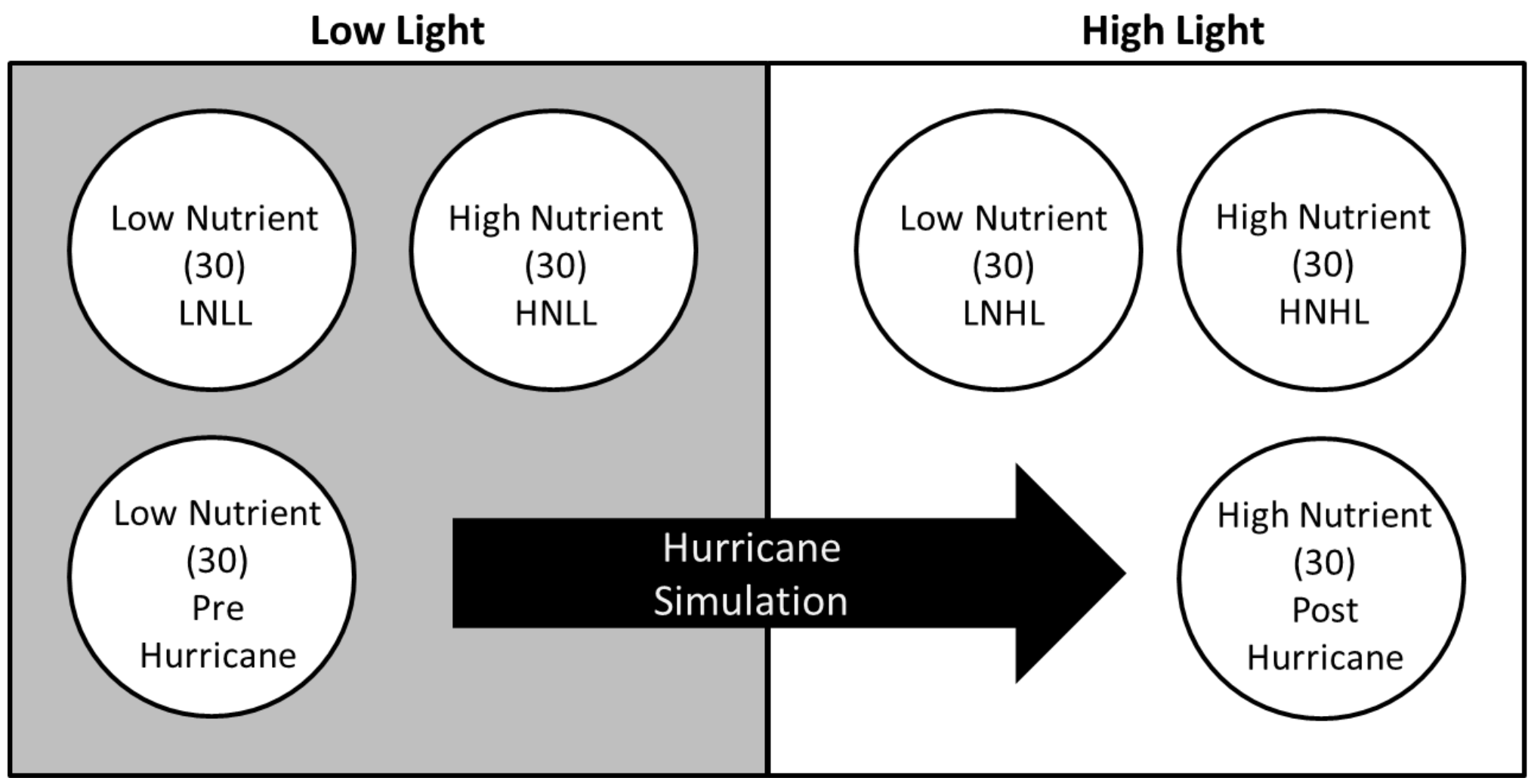

Figure V.1: Conceptual design of the experimental set up with the four factorial treatments (top row) and simulated hurricane treatment (bottom row). 

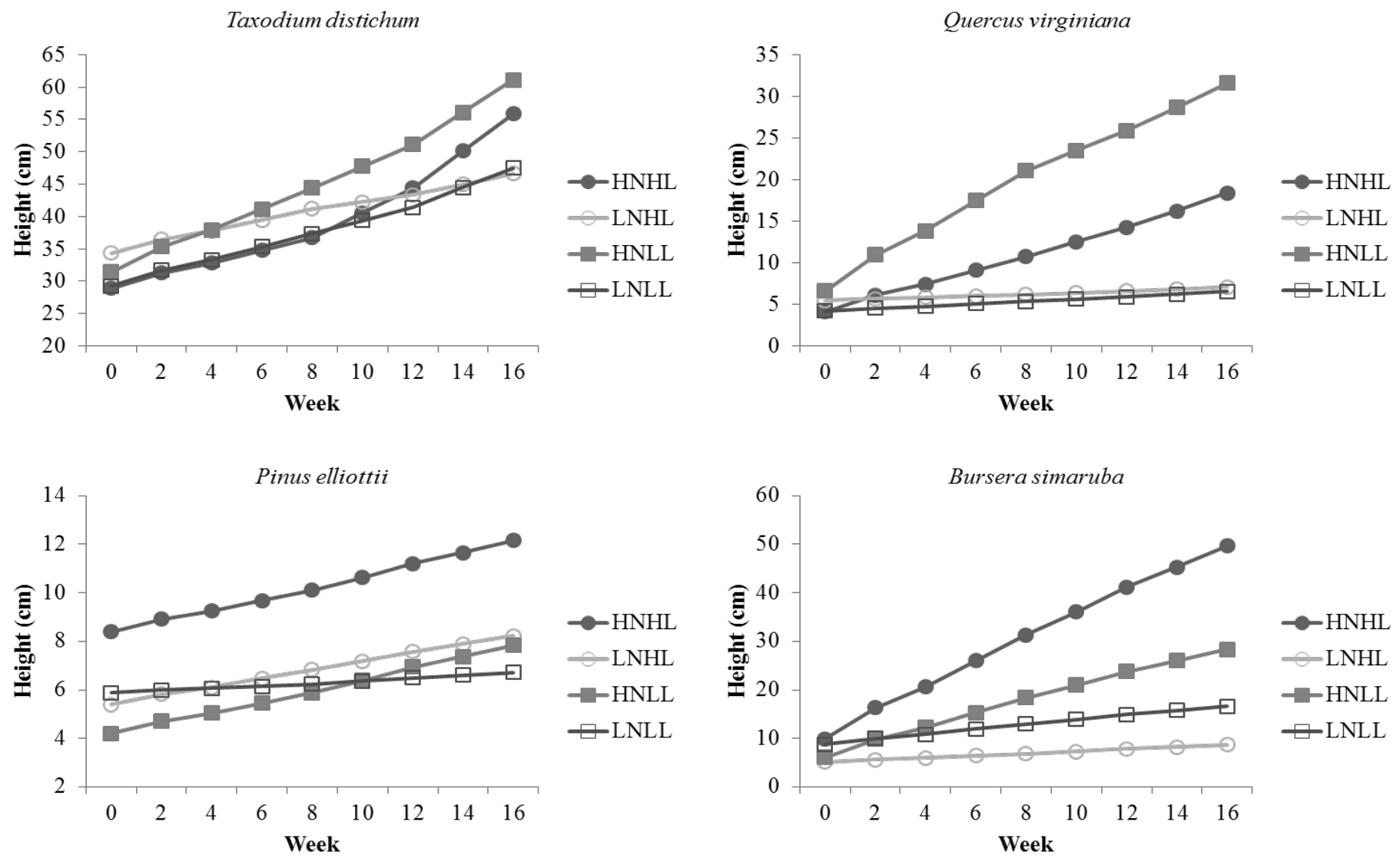

Figure V.2: Tree species seedling shoot weekly growth rates according to high nutrient/high light (HNHL), low nutrient/high light (LNHL), high nutrient/low light (HNLL), and low nutrient/low light (LNLL). 

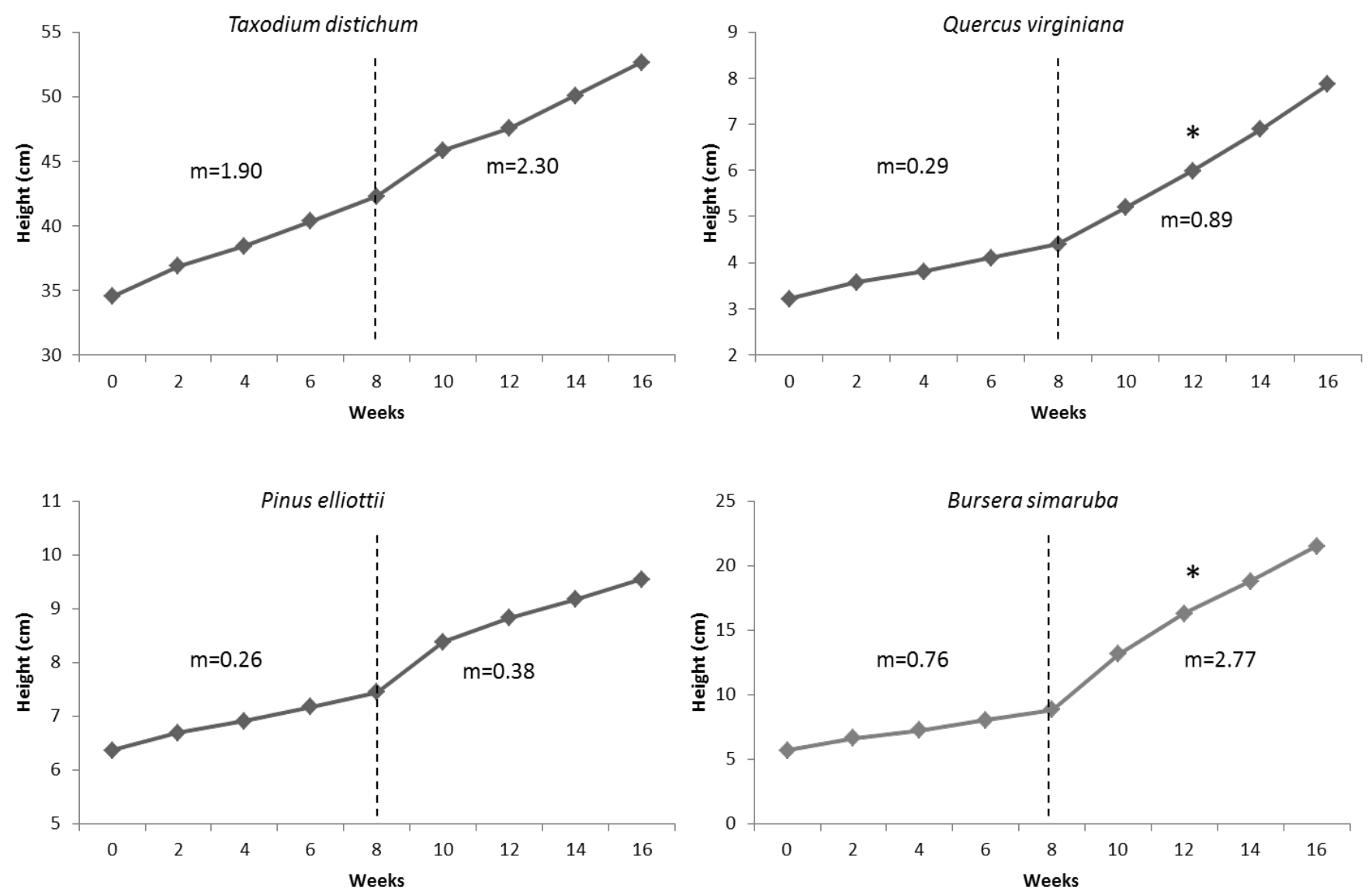

Figure V.3: Tree species seedling shoot weekly growth rates for pre-hurricane treatment and post-hurricane simulation treatment, with hurricane simulation treatment indicated by vertical dashed line. Slopes $(\mathrm{m}, \mathrm{cm} / \mathrm{week})$ and statistical significance of preversus post-hurricane simulation growth rates $(*)$ are indicated as a result of analysis of co-variance. 

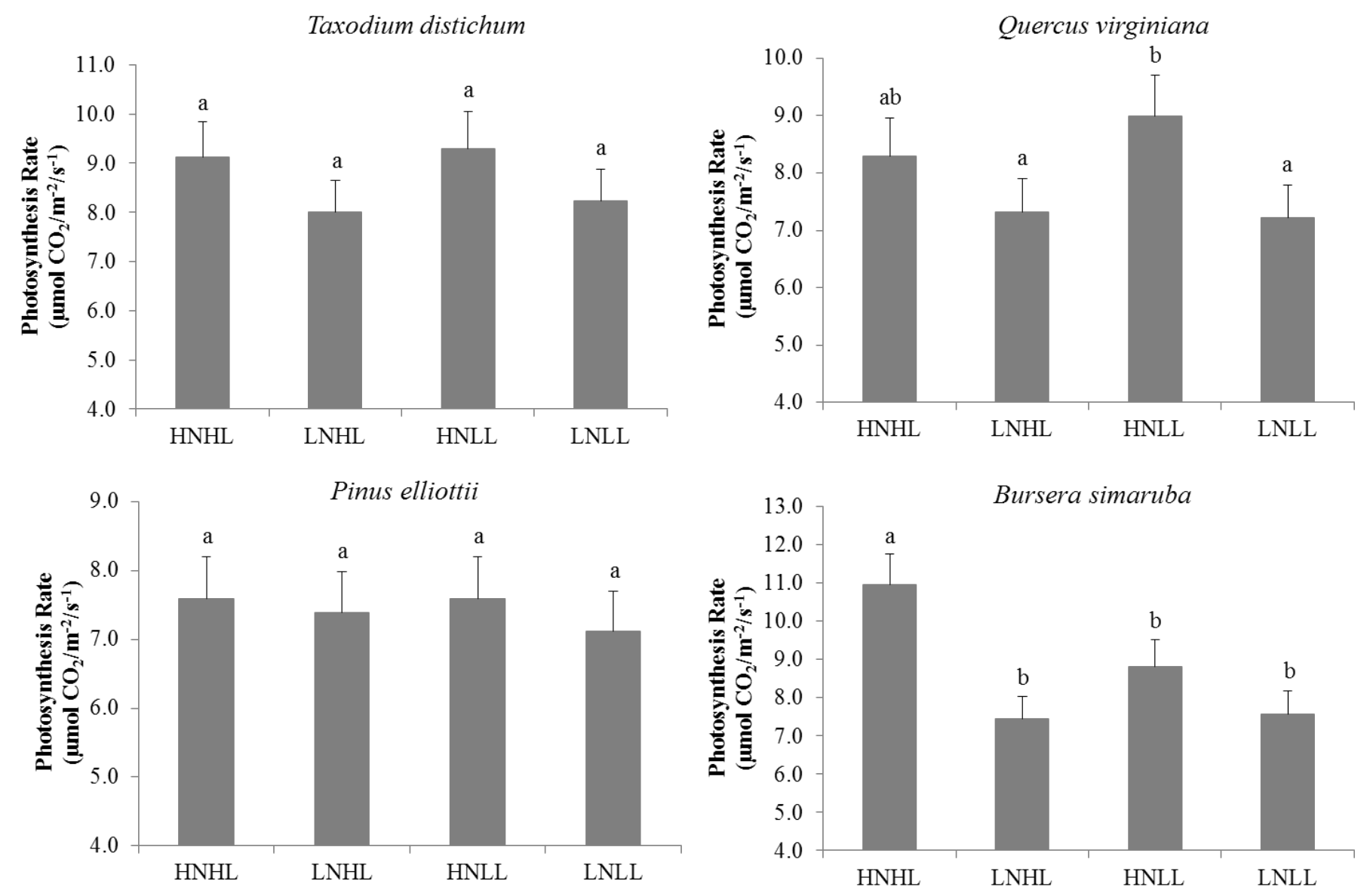

Figure V.4: Tree species seedling photosynthesis rates according to high nutrient/high light (HNHL), low nutrient/high light (LNHL), high nutrient/low light (HNLL), and low nutrient/low light (LNLL). Letters indicate results of Tukey’s post-hoc analysis and error bars indicate standard error. $(\mathrm{n}=10)$. 

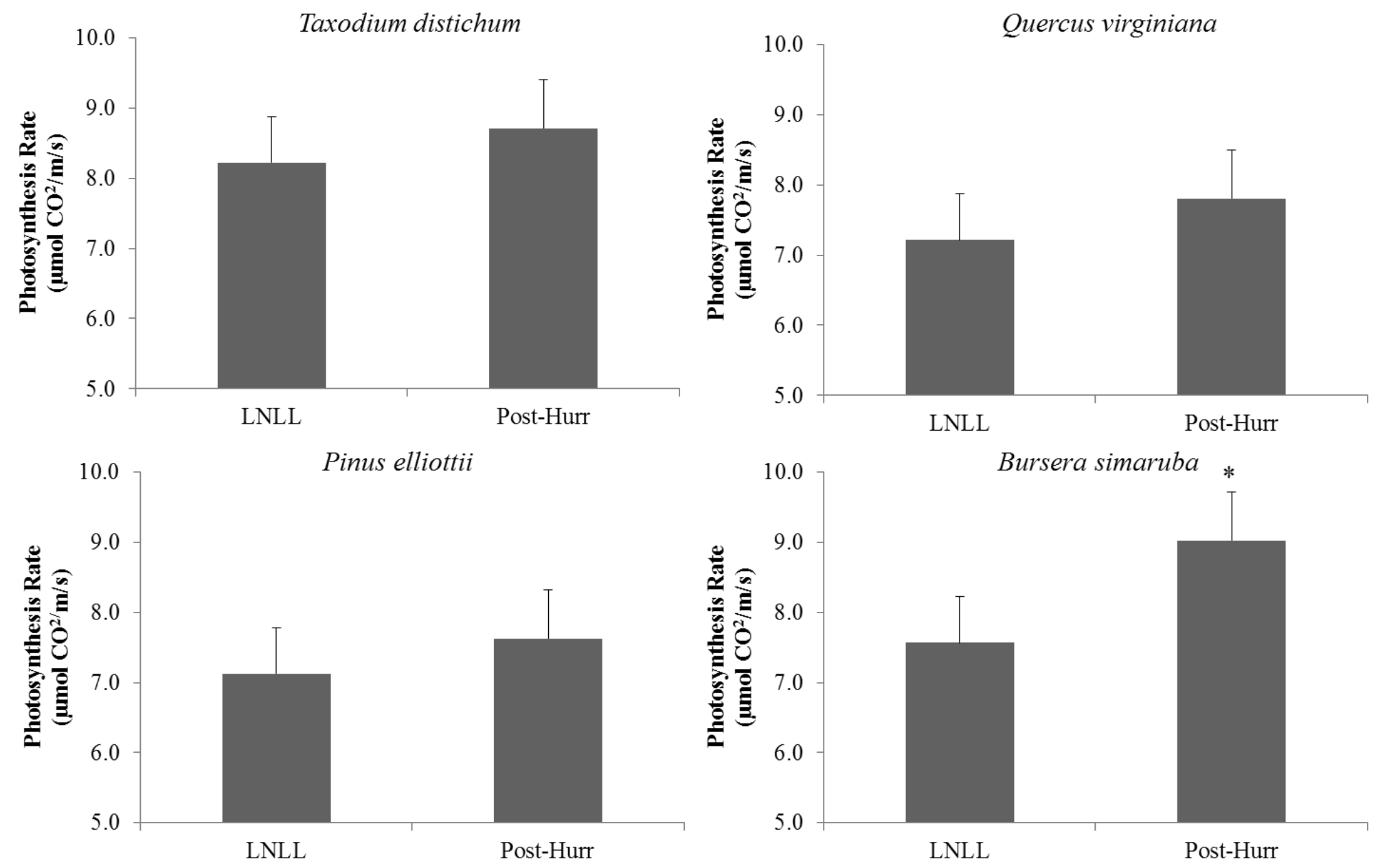

Figure V.5: Tree species seedling photosynthesis rates according to low nutrient/low light (LNLL) and post-hurricane simulation treatments. Error bars indicate standard error. * denotes statistical significance. $(n=10)$ 

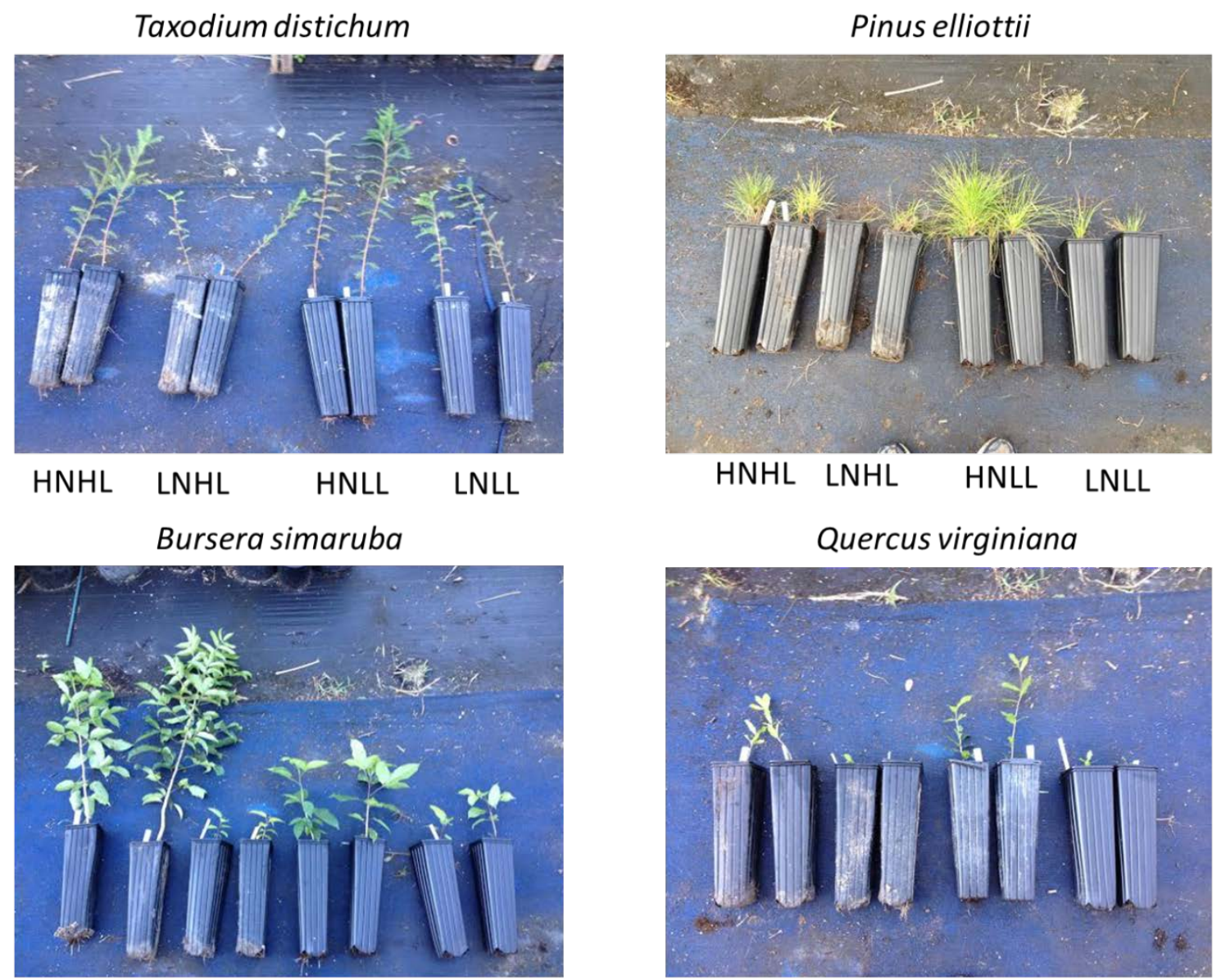

HNHL LNHL HNLL LNLL

HNHL LNHL HNLL LNLL

Quercus virginiana

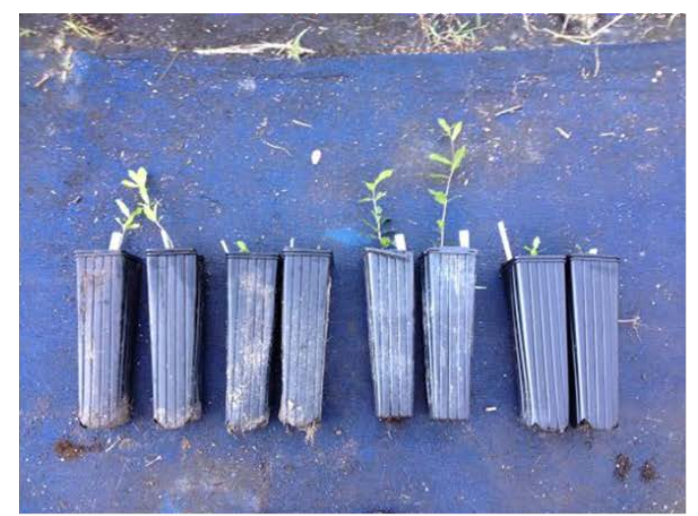

HNHL LNHL HNLL LNLL

Figure V.6: Images of seedling size after 16 weeks of treatment with high nutrient/high light (HNHL), low nutrient/high light (LNHL), high nutrient/low light (HNLL), and low nutrient/low light (LNLL). 


\section{VI: Synthesis and Relevance}

The previous four chapters of this dissertation evaluate the changes that four Everglades forest communities underwent during their recovery after Hurricane Andrew. Each chapter outlined unique aspects of this recovery process and in this final chapter the key findings of each will be summarized and synthesized. The summary findings are also inserted into the conceptual flowchart from Chapter I (Figure VI.1).

Chapter II documented change in forest community structure and function after hurricane impact across temporal and spatial scales. Throughout this project the majority of the four community types behaved in similar fashion over the duration of the study period, albeit to varying degrees. After 20 years of recovery, soil and leaf nitrogen levels demonstrated no correlation with initial damage extent, suggesting that any alteration of nutrient levels as a result of hurricane impact had subsided within almost all of the communities. Canopy closure after storm-associated defoliation was fast (over the first 34 years) and remained similar to canopy closure measurements taken after 20 years. Growth rates over the length of the study were species-specific in magnitude and direction after the hurricane with a trend of higher growth rates during the initial (3 year) recovery period before slowing over the long-term (20 year) period. Combined, these findings suggest that almost every measured aspect of each of the four forest communities were fully recovered from Hurricane Andrew after 20 years with little residual effect on community structure or function.

Species mortality and diversity shifts outlined in Chapter III indicate that damage extent can lead to delayed mortality, which can leave a lasting effect on community 
diversity. Most of the survey plots and communities showed very little individual mortality during the initial recovery period, however longer time periods (20 years) demonstrate that many of these individuals that initially recovered did not ultimately survive. Individual mortality was the highest over both recovery time periods for trees occupying the smallest size classes, while individuals occupying intermediate size classes were more likely to survive and grow up into even larger classes. Disturbance-adapted species fared much better overall compared to non-disturbance adapted species, often increasing in presence while the latter disappeared from plots. Redundancy of many individuals from a few species in pinelands and cypress domes meant that even with individual losses, diversity did not appreciably decrease, in contrast to the more diverse communities such as hardwood hammocks and bayhead tree islands.

Results from Chapters I and II indicate that community attributes shift across varying time scales during the recovery process and each community responds in a unique manner. Community structure and function are greatly affected by hurricane impact in the short-term, but these effects dissipate over time and after 20 years are unable to be detected. Conversely, community composition and diversity do not change in the short-term, but delayed mortality leads to a loss of species richness in more diverse communities. While a community may seem to have fully recovered from the initial hurricane impact, this apparent structural recovery may be overshadowed by a more longterm biodiversity loss.

The M2 model proposed and tested in Chapter IV demonstrates the ability to predict long-term (20 year) individual growth rates using short-term (3 year) growth rate 
and individual damage assessment data. Most species in the study did not maintain enough frequency or survival over the length of the study to be included, so only $T$. distichum (in cypress domes) and six hardwood hammock species were included in the model. Hardwood hammock species growth rates were reasonably predicted over the long-term time scale although the model was best at predicting long-term growth rates of T. distichum in cypress domes. The model was also effective at predicting the size of individuals in all four study communities regardless of species.

The model proposed in Chapter IV is likely best applied to regions in which $T$. distichum is the dominant canopy species, because model predictions were the most accurate in these communities. In particular, the application and further testing of this model would be beneficial in areas of the Southeast United States where cypress forests often dominate near-shore areas that are likely to incur hurricane damage. The benefit of using this model, compared to others, is its inherent simplicity and ease of use. Assessments of initial damage extent and growth rates for use as variables in this model are more cost and time effective than data required by other models. This level of easeof-use, coupled with its effectiveness, demonstrates that this model warrants validation studies in other systems that are hurricane impacted.

The shadehouse component of this dissertation, Chapter V, followed a cohort of canopy species recruits through four months of a light/nutrient manipulation and simulated hurricane effect study. Overall, increased levels of soil nutrients had more effect on growth, photosynthesis, and resource allocation than increased levels of incoming solar radiation. Study species with faster growth rates (T. distichum and $B$. 
simaruba) responded to more favorable conditions by increasing growth rates while maintaining the same proportions of tissue allocation. Alternatively, slower growing species (Q. virginiana and P. elliottii) changed little in growth rate yet shifted tissue allocation toward structures that would help with the acquisition of the limiting resource.

Plasticity responses to hurricane simulation in the shadehouse study were speciesspecific, but trends were similar to those mentioned in the previous paragraph. Bursera simaruba was the only species to have growth rates that significantly increased after simulated hurricane treatment. Both T. distichum and B. simaruba increased overall productivity after simulation, but tissue allocation remained fairly constant pre- and postsimulation. Once again the slower growing species, Q. virginiana and P. elliottii, did not alter growth rates or overall productivity post-simulation. Instead, they responded by shifting tissue allocation from belowground (pre-hurricane simulation) to aboveground (post-hurricane simulation).

The findings of the shadehouse portion of this study demonstrated the differences in adaptive strategies in response to varying environmental conditions. Both of the conifer species, $T$. distichum and $P$. elliottii, responded differently to varying environmental conditions. Both species, however, occupy communities within the Everglades that have a strong stressor (deep water and frequent fire, respectively). This stress tolerance will likely ensure their success in their specific communities despite their degree of plasticity and ultimate response. For this study B. simaruba served as the model tropical, fast-growing species and Q. virginiana served as the model temperate, slow growing species. Comparison of these two species in particular shows that in the post- 
hurricane simulation Q. virginiana shifted tissue allocation, but it did not change overall productivity while B. simaruba did not shift allocation but rather increased production. This study provides results that predict that B. simaruba would out compete $Q$. virginiana in the newly favorable, post-hurricane conditions and possibly grow into the canopy. Not coincidentally, B. simaruba also showed the highest growth rates in the field study (Chapter II).

This dissertation highlights the increased need for long-term community monitoring after hurricane impact. The spatial and especially temporal shift in composition and structure demonstrate that while the community may appear to fully recover over the first few years post-hurricane there can also be more long-term shifts that do not manifest until much longer. Trends in diversity loss indicate a loss of rare species and an overall increase in tropical and faster growing species. These long-term shifts are often species dominance and diversity shifts that can affect the conservation of rare or threatened species and the region as a whole. 


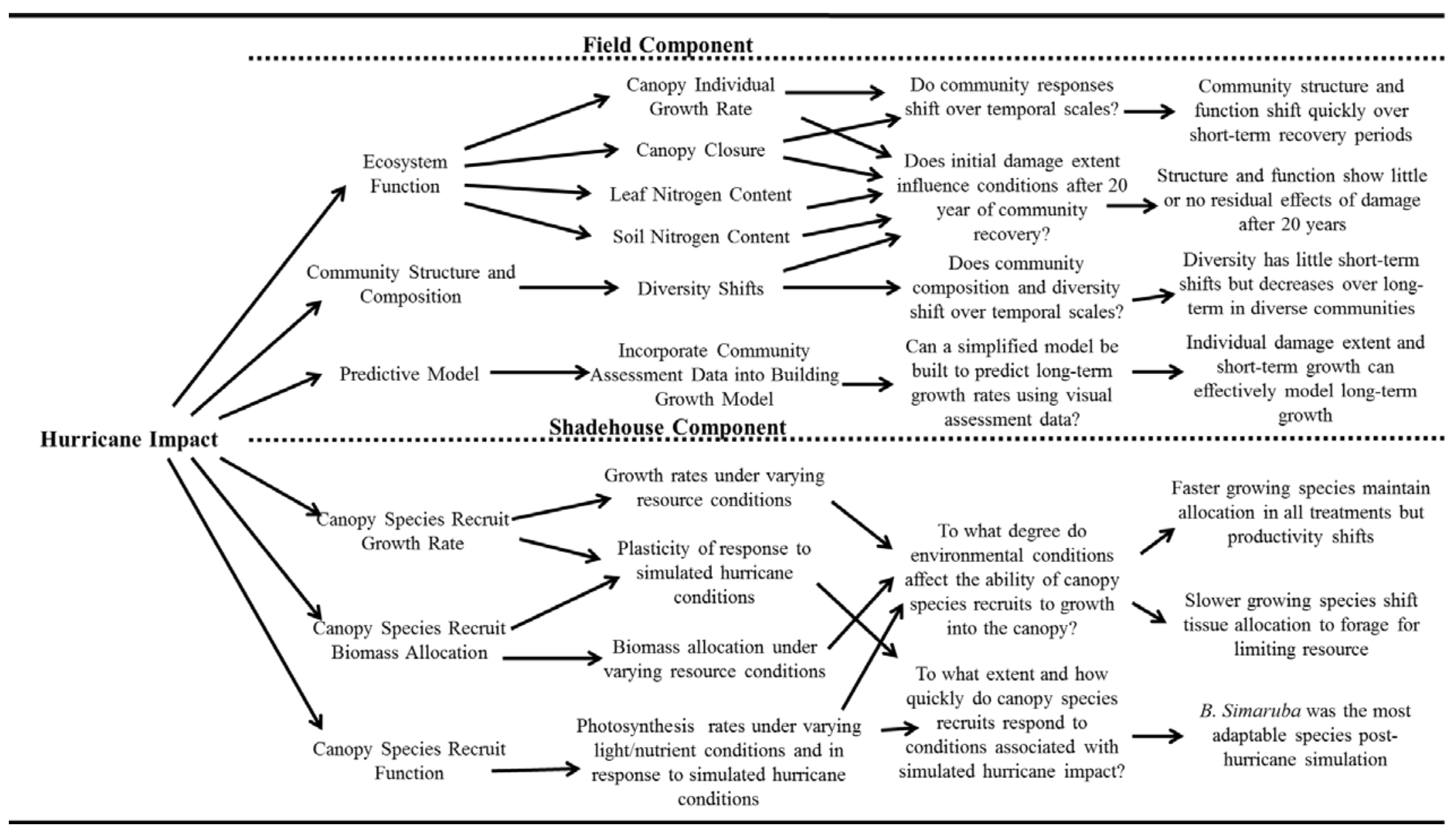

Figure VI.1: Flowchart describing field and shadehouse components of the project and the relation of these components to the main research questions and findings. 
VITA

JEREMY L. MAY

Born, Bloomington Indiana

2008

B.S., Biology

Grand Valley State University

Allendale, Michigan

2011

M.S. Biology

Grand Valley State University

Allendale, Michigan

2013-2016

Doctoral Candidate

Florida International University

Miami, Florida

Teaching Assistant

Florida International University

Miami, Florida

\section{PUBLICATIONS AND PRESENTATIONS}

Robert D. Hollister, Jeremy L. May, Kelsey S. Kremers, Craig E. Tweedie, Steven F. Oberbauer, Jennifer A. Liebig, Timothy F. Botting, Robert T. Barrett, and Jessica L. Gregory. 2015. Warming Experiments Elucidate the Drivers of Observed Directional Changes in Tundra Vegetation. Ecology and Evolution. 5(9): 1881 1895.

May, JL*, SF Oberbauer. Comparison of using handheld and Mobile Instrumented Sensor Platform NDVI measurements to track associated plant activity period at Toolik Lake, Alaska ITEX site. $21^{\text {st }}$ International Tundra Experiment Meeting 2015. September 16 18, 2015. Uppsala, Sweden.

May, JL*, SF Oberbauer. Influence of varying environmental conditions on canopy species recruits from four Everglades plant communities. Greater Everglades Ecosystem Restoration Meeting. April 21-23, 2015.. Coral Springs, FL.

Jeremy L. May, Robert D. Hollister. 2012. Validation of a Shortcut to the Point Frame Method to Detect Change in Tundra Vegetation. Polar Biology. 35 (12). 18151823. 
November 12, 2014. "Growth rate and resource allocation responses of canopy species recruitsfrom four Everglades plant communities to varying light and nutrient regimes” Plant Talk Series. Florida International University.

January 26, 2012. “Documenting Vegetation Response to Warming in Northern Alaska” Plant Talk Series. Florida International University.

Sarah C. Elmendorf, ....Jeremy L. May,... and 39 others. 2012. Global assessment of experimental climate warming on tundra vegetation: heterogeneity over space and time. Ecology Letters. 15: 164-175.

Sarah C. Elmendorf, ... Jeremy L. May, ... and 39 others. 2012. Plot-scale evidence of tundra vegetation change and links to recent summer warming. Nature Climate Change. 2: 453-457.

Jeremy L. May. 2011. Documenting Tundra Plant Community Change in Northern Alaska. Masters Thesis. Grand Valley State University. Allendale, Michigan. 